\title{
EVERLAYNY FIOROT COSTALONGA
}

\section{Farmacogenética do tratamento com hormônio de crescimento (GH) em crianças com deficiência de GH}

\author{
Tese apresentada à Faculdade de Medicina da \\ Universidade de São Paulo para a obtenção de título \\ de Doutor em Ciências \\ Programa de Endocrinologia \\ Orientador: Prof. Dr. Alexander Augusto de Lima Jorge
}

São Paulo

2010 


\section{Dados Internacionais de Catalogação na Publicação (CIP)}

Preparada pela Biblioteca da

Faculdade de Medicina da Universidade de São Paulo

Creprodução autorizada pelo autor

\section{Costalonga, Everlayny Fiorot}

Farmacogenética do tratamento com hormônio de crescimento (GH) em crianças com deficiência de GH / Everlayny Fiorot Costalonga. -- São Paulo, 2010.

Tese(doutorado)--Faculdade de Medicina da Universidade de São Paulo. Programa de Endocrinologia.

Orientador: Alexander Augusto de Lima Jorge.

Descritores: 1.Farmacogenética 2.Medicina individualizada 3.Hormônio do crescimento/deficiência 4.Hormônio do crescimento humano/genética 5. Hormônio do crescimento humano/uso terapêutico 6.Receptores da somatotropina/genética 7.Fator de crescimento insulin-like I/genética 8.Proteínas de ligação a fator de crescimento insulin-like/genética 9.Polimorfismo genético/efeitos de drogas 
Este trabalho foi realizado na Unidade Endocrinologia do Desenvolvimento e no Laboratório de Hormônios e Genética Molecular LIM 42 da Disciplina de Endocrinologia do Hospital das Clínicas da Faculdade de Medicina da Universidade de São Paulo, com apoio Fundação de Amparo à Pesquisa do Estado de São Paulo (FAPESP): Projeto Temático 05/04726-0 e Bolsa de Doutorado 06/55763-5 


\section{Dedicatória}

Dedico esta tese sobretudo a minha mãe, minha suprema fonte de força, apoio e inspiração nessa tão fascinante e edificante busca pelo conhecimento 


\section{Agradecimentos}

Difícil começar sem falar de conquista... Quem ama o conhecimento como eu sabe o quanto é difícil concluir um trabalho de pesquisa com todo carinho e dedicação...

Mas a oportunidade que me foi concedida ao desenvolver esse trabalho foi muito além de uma enorme conquista profissional... Como parte integrante de um mundo culturalmente massificado em que somos permanentemente estimulados a não questionar, sinto-me privilegiada pela oportunidade do convívio com verdadeiros amantes da arte de perguntar, responder, e por que não perguntar de novo e responder novamente...Além do intenso crescimento pessoal proporcionado pelas experiências vividas ao longo do período, pude aprimorar habilidades fundamentais para a percepção mais crítica das informações às quais somos bombardeados crescentemente nos dias atuais. Num meio em que pensar e questionar premissas é "um pouco menos perigoso ", pude aprender diferentes formas de perguntar pertinentemente e de responder não só de forma crítica, mas também realistica e honesta; já que questionar sem a coragem de assumir limitações pode se tão "perigoso" quanto viver de forma alienada. Dessa forma, acredito que a conclusão dessa tese represente na minha vida muito mais que o início de uma formação acadêmica; uma vez que as habilidades desenvolvidas são de ampla aplicabilidade pessoal e profissional no contexto em que vivemos atualmente. 
Nada disso seria possível sem a presença constante na minha vida de pessoas que me fazem lembrar a todo o momento o quão engrandecedoras podem ser quaisquer relações inter-humanas. Inicialmente, agradeço imensamente à minha família como um todo, sempre tão carinhosa comigo; e de forma especial a minha mãe, meu pai e meu irmão, pessoas a quem amo e admiro numa intensidade que palavra nenhuma pode expressar. A minha mãe, Elida, sem dúvida alguma minha maior mestre, eterna fonte de amor e de estímulo ao prazer de saber e de compartilhar o saber. A meu irmão, Elerson, pelo carinho, lucidez e serenidade constantes que tanto me serviram de apoio nesse caminho. E a meu pai, José Carlos, que, mesmo sem saber ao certo o objetivo de "tanto estudo", simplesmente me amou e me apoiou com seu jeito simples de ver a vida. Também a Giseli, minha "irmã mais velha", exemplo de força e fragilidade ao mesmo tempo, companheira nos momentos de alegrias e de tristezas; e Gertraude, nova amiga e fonte de equilíbrio nessa reta final.

Agradecimentos sem limites ao meu orientador, meu "chefe", Prof.Dr. Alexander Augusto, fonte de conhecimento, apoio, estímulo, humanidade; um mestre e amigo no sentido mais amplo possível dessas palavras. Além de inteligente, excelente pesquisador e um orientador sempre presente, sabe valorizar e cultivar o aspecto humano de cada aluno, de forma a extrair e compartilhar de forma brilhante o que há de melhor em cada um de nós. Um anjo que veio me ensinar a "me divertir" com a arte de pesquisar com responsabilidade e sem sofrimento. 
Ao Prof. Dr. Ivo, pela contribuição constante com sua inteligência extraordinária, perspicácia, simplicidade e serenidade que engrandecem qualquer discussão; além do apoio sempre gentil e fundamental nos "assuntos internacionais".

À Profa. Dra. Berenice, mestre de meu mestre e a grande responsável pelo enorme sucesso interpessoal e científico do grupo, o melhor exemplo de líder que já conheci. Pelo apoio científico, cultural e humano que oferece a todos nós; e especialmente pelo privilégio de ter me concedido seu valoroso voto de confiança e carinho em todos os momentos dessa minha jornada.

Às minhas "irmãs" tão amadas, Luciana Montenegro, Débora, Andréia, Alexsandra, Patrícia, Adriana, e as "adotadas" Marcela, Aline, Fernanda. Amigas que, apesar de terem me "roubado o chefe" por tantas vezes, por tantas mais me apoiaram, me fizeram rir, me ensinaram e me fizeram voltar a acreditar que nunca é tarde para fazer amizades de imenso valor com quem sabemos que podemos contar para o resto de nossas vidas. E um agradecimento especial à Adri, que, além de ter me auxiliado no inglês nessa reta final, tem sido uma grande companheira ao dar seguimento a esta linha de pesquisa.

Aos demais amigos do laboratório, especialmente Luciani - com sua alegria contagiante, exemplo de humildade e gentileza admiráveis, Luciana Brito e Carol - pessoas especiais, de integridade e força de carácter impecáveis - e Ana Paula - que apesar da distância na reta final foi fundamental nas fases inciais dessa aventura. Também a Milena, por ter sido meu primeiro contato com o grupo. A Rocio, pelo auxílio nas 
genotipagens. Às Dras Tania, Elaine, Ana Claudia, Cândida, pela simpatia, exemplo e apoio constantes. A Miriam Nishi, Cris, Cidinha, Fran, Mariana, pelo trabalho e dedicação carinhosos e fundamentais para que toda produção cientifica do laboratório seja possivel. A Emilia, pelo auxílio nas fases iniciais da minha aventura pelo mundo molecular. Às secretárias Cris, Ana e sobretudo Nilda, pela eficiência impecável e por sempre estarem disponíveis para nos auxiliar com tanto carinho nos assuntos administrativos. E aos demais amigos do LIM 42, Maíra, Antônio, Frederico, Karina, Maria Estela, Viviani, Leticia, Priscila, Larissa, Regina, Vinícius, Soraia e todos os demais componentes que fazem do LIM 42, um local de trabalho extremamente agradável, instigante e prazeroso.

Ao Prof Dr Sonir Roberto Antonini e Prof. Dr Gil Guerra-Junior pela prestatividade, gentileza e confiança, que contribuiram não só no sentido de apoiar a realização da pesquisa, mas também ao ampliar minha visão e admiração pelas pessoas que estão por traz dos grandes pesquisadores, tais como eles são.

Aos pacientes, exemplo de perseverança, sempre prestativos a participar desse processo de construção do conhecimento, cujo olhar de agradecimento nos impulsiona sempre na busca por descobrir mais e mais.

E finalmente à FAPESP, pelo voto de confiança e apoio financeiro nessa longa jornada de luta e dedicação. 


\section{Epígrafe}

"Há homens que lutam um dia e são bons.

Há outros que lutam um ano e são melhores. Há os que lutam muitos anos e são muito bons.

Porém, há os que lutam toda a vida. Esses são os imprescindíveis." Bertolt Brecht 


\section{Sumário}

Lista de Abreviaturas

Lista de Símbolos

Lista de Figuras

Lista de Tabelas

Lista de Quadros

Resumo

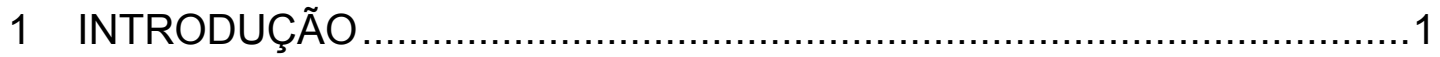

1.1 Farmacogenética e estudos de associação genética.....................6

1.2 Farmacogenética do tratamento com $\mathrm{rhGH}$..............................9

1.3 Mecanismos de ação do GH e eixo GH-IGF-1 ..........................11

1.4 Polimorfismos candidatos ................................................ 13

1.4.1 Gene do Receptor do Hormônio do Crescimento (GHR).......13

1.4.1.1 Presença ou ausência do exon 3 do GHR ...................14

1.4.1.2 Polimorfismo p. Ile544Leu do GHR ...........................18

1.4.2 Gene do Fator de Crescimento Insulina Símile-1 (IGF1)......19

1.4.2.1 Microssatélite (CA)n da região promotora do IGF1 .......19

1.4.3 Gene da Proteína Transportadora de IGFs - 3 (IGFBP3) ......20

1.4.3.1 Polimorfismo -202 A/C da região promotora do IGFBP3 ...21

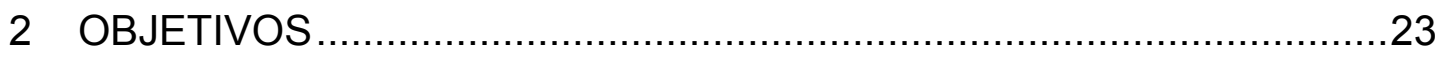

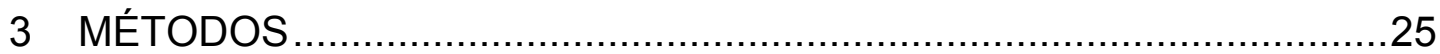

3.1 Considerações éticas .....................................................26

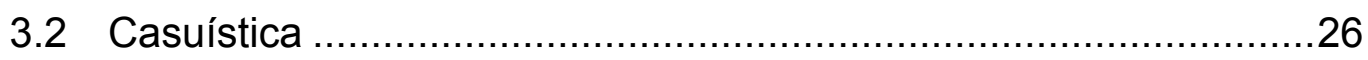

3.3 Protocolo de acompanhamento clínico ...................................28

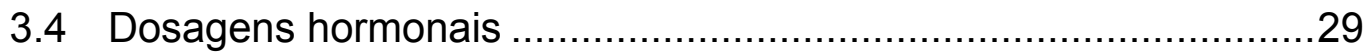

3.5 Coleta de dados para análises multivariadas..........................30

3.6 Estudos Moleculares ............................................................ 31

3.6.1 Preparação das amostras- extração de DNA genômico ........31

3.6.2 Metodologias de genotipagem.....................................32

3.6.2.1 Presença ou ausência do exon 3 do GHR ...................32

3.6.2.2 Polimorfismo p. Ile544Leu do GHR ............................33 
3.6.2.3 Microssatélite (CA)n na região promotora do IGF1 .......35

3.6.2.4 Polimorfismo -202 A/C da região promotora do IGFBP3 ...36

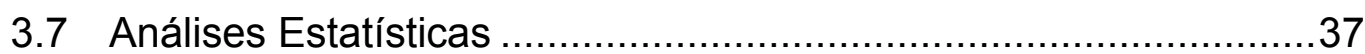

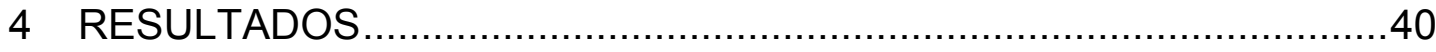

4.1 Caracterização da casuística ..................................................41

4.2 Distribuição genotípica ......................................................43

4.3 Análises de associações com a capacidade de resposta ao tratamento com rhGH...................................................... 44

4.3.1 Variáveis Clínicas ......................................................44

4.3.2 Variáveis Genéticas ..................................................45

4.3.2.1 Presença ou ausência do exon3 do GHR ...................45

4.3.2.2 Polimorfismo p.Leu 544 Ile do GHR ............................46

4.3.2.3 Microssatélite (CA)n do IGF1 ................................47

4.3.2.4 Polimorfismo -202 A/C do IGFBP3............................50

4.3.2.5 Efeito interativo entre os polimorfismos estudados .......54

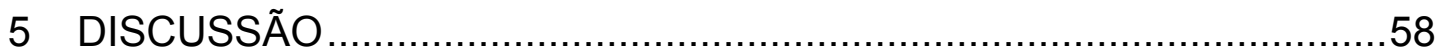

5.1 Presença ou ausência do exon 3 do GHR .................................59

5.2 Polimorfismo p.Ile544Leu do GHR ........................................62

5.3 Microssatélite (CA)n do IGF1 ...........................................63

5.4 Polimorfismo -202 A/C do IGFBP3......................................64

5.5 Efeitos interativos ................................................................ 67

5.6 Considerações finais e perspectivas .......................................68

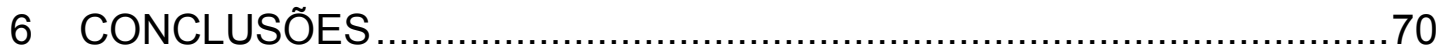

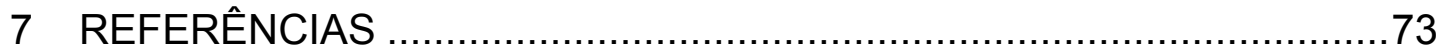

\section{APÊNDICES}

1. Artigo de revisão publicado no Arquivos Brasileiros de Endocrinologia e Metabologia (2008)

2. Artigo original publicado no Journal of Clinical Endocrinology and Metabolism (2009) 


\section{Lista de abreviaturas}

$\begin{array}{ll}\text { ACTH } & \text { Hormônio corticotrófico } \\ \text { AFH } & \text { Hormônio antidiurético } \\ \text { ALS } & \text { Altura final } \\ \text { (CA)n } & \text { Subunidade ácido lábil } \\ \text { DGH } & \text { Repetições citosina - adenosina de número variável } \\ \text { DGHC } & \text { Deficiência de hormônio de crescimento } \\ \text { DGHI } & \text { DGH combinada a outras deficiências hipofisárias } \\ \text { DNA } & \text { Deficiência de GH isolada } \\ \text { DP } & \text { Ácido desoxirribonucleico } \\ \text { F } & \text { Desvio-padrão } \\ \text { GH } & \text { Feminino } \\ \text { GHR } & \text { Hormônio de crescimento } \\ \text { GHRd3 } & \text { Receptor de hormônio de crescimento } \\ \text { GHRfl } & \text { Alelo do GHR com deleção do exon 3 } \\ \text { GHRd3/* } & \text { Alelo do GHR completo ( sem deleção do exon 3) } \\ \text { GnRH } & \text { Genótipo apresentando pelo menos 1 alelo GHRd3 } \\ \text { HDL } & \text { Hormônio liberador de gonadotrofinas } \\ \text { IFMA } & \text { Lipoproteína de alta densidade } \\ \text { IGF-1 } & \text { Ensaio imunofluorimétrico } \\ \text { IGFBP-3 } & \text { Proteína linas ligadoras de IGFs (IGF binding proteins) } \\ \text { IGFBPs } & \end{array}$


Ile

IMC

IQMA

IRMA

JAK 2

LD

LDL

Leu

M

não 19CA

não 19CA / *

19/19 CA

$\mathrm{pb}$

PCR

rhGH

RIA

RNA

RNAm

SNP

SOCS

Stat5b

$\mathrm{TRH}$

TSH

TH
Isoleucina

Índice de massa corporal

Ensaio de quimioluminescência

Ensaio imunorradiométrico

Janus quinase -2

Desequilíbrio de ligação

Lipoproteína de baixa densidade

Leucina

Masculino

Alelo do locus (CA)n IGF1 diferente de 19 repetições CA

Genótipo contendo pelo menos 1 alelo não 19CA

Genótipo homozigoto para o alelo de 19 repetições CA

pares de bases

Reação em cadeia da polimerase

Hormônio de crescimento recombinante humano

Radioimunoensaio

Ácido ribonucleico

RNA mensageiro

Polimorfismo de base única

Supressors of cytokine signaling

Signal transducers and activator of transcription $B$ Hormônio liberador de TSH

Hormônio tireotrófico

Target height (altura-alvo) 
VC

Z

$\mathrm{Z} A F-\mathrm{ZTH}$
Velocidade de crescimento

Escore de desvio-padrão

$\mathrm{Z}$ da altura final ajustado pelo $\mathrm{Z}$ da target-height 


\section{Lista de Símbolos}

\begin{tabular}{|c|c|}
\hline$A$ & Adenosina \\
\hline C & Citosina \\
\hline $\mathrm{C} /{ }^{*}$ & Genótipo contendo pelo menos um alelo C \\
\hline \pm & mais ou menos \\
\hline$\Delta$ & delta (variação durante determinado período) \\
\hline $\mathrm{cm} / \mathrm{ano}$ & centímetros por ano \\
\hline $\mathrm{cm}$ & Centímetros \\
\hline G & Gramas \\
\hline $\mathrm{Kb}$ & Quilobase \\
\hline LN & Log natural \\
\hline $\mathrm{mg} / \mathrm{L}$ & miligramas por litro \\
\hline $\mathrm{ng} / \mathrm{mL}$ & nanogramas por mililitros \\
\hline$<$ & menor que \\
\hline$>$ & maior que \\
\hline$=$ & Igual a \\
\hline$\leq$ & menor ou igual a \\
\hline$\geq$ & maior ou igual a \\
\hline$\mu g / k g / d i a$ & microgramas por quilo por dia \\
\hline $\mathrm{mg} / \mathrm{kg} / \mathrm{dia}$ & miligramas por quilo por dia \\
\hline
\end{tabular}




\section{Lista de Figuras}

Figura 1: Variabilidade de respostas de crescimento em crianças com deficiência de $\mathrm{GH}$ tratadas com $\mathrm{GH}$ no serviço de Endocrinologia do Desenvolvimento do HC-FMUSP.

Figura 2: Esquema do mecanismo de transdução do sinal mediado por $\mathrm{GH}$

Figura 3: Representação esquemática da estrutura do gene do GHR .....13

Figura 4: PCR multiplex para genotipagem da presença ou ausência do exon 3 do $G H R$

Figura 5: Foto de gel de agarose contendo produtos de digestão enzimática para genotipagem do SNP p.Ile544Leu do GHR .....34

Figura 6: Representação gráfica da associação entre o genótipo -202 A/C IGFBP3 e o $Z$ de IGFBP-3 sérica antes e durante 0 tratamento com rhGH

Figura 7: Representação gráfica da associação entre o genótipo -202 A/C IGFBP3 e a velocidade de crescimento no primeiro ano de tratamento com rhGH

Figura 8: Representação gráfica da influência combinada dos genótipos -202 A/C IGFBP3 e (CA)n IGF1 sobre a velocidade de crescimento no primeiro ano de tratamento com rhGH

Figura 9: Representação gráfica da influência combinada dos genótipos GHR-exon3 e (CA)n IGF1 sobre o Z de altura final ajustado pelo $Z$ da altura-alvo 


\section{Lista de Tabelas}

Tabela 1: Apresentação resumida dos trabalhos que avaliaram a influência do genótipo GHR-exon3 sobre diferentes parâmetros de sensibilidade ao $\mathrm{GH}$.

Tabela 2: Características clínicas e auxológicas dos pacientes selecionados

Tabela 3: Lista dos genes e respectivos polimorfismos selecionados: distribuição genotípica na presente casuística.

Tabela 4: Influência do genótipo GHR-exon3 sobre a resposta ao tratamento com rhGH

Tabela 5: Influência do polimorfismo p.Leu 544 lle do GHR sobre a resposta ao tratamento com rhGH

Tabela 6: Influência do genótipo (CA)n IGF1 sobre a resposta ao tratamento com rhGH a curto prazo.

Tabela 7: Influência do genótipo (CA)n IGF1 sobre a resposta ao tratamento com rhGH a longo prazo

Tabela 8: Influência do genótipo -202 A/C IGFBP3 sobre as concentrações séricas de IGFBP-3 antes e durante 0 tratamento com rhGH

Tabela 9: Influência do genótipo -202 A/C IGFBP3 sobre a resposta ao tratamento com rhGH

Tabela 10: Influência combinada dos genótipos -202 A/C IGFBP3 e (CA)n IGF1 sobre a velocidade de crescimento no primeiro ano de tratamento com rhGH.

Tabela 11: Influência combinada dos genótipos GHR-exon3 e (CA)n IGF1 sobre o $Z$ de altura final ajustado pelo $Z$ da altura-alvo após tratamento com rhGH. 


\section{Lista de Quadros}

Quadro 1: Fatores determinantes da capacidade de resposta ao tratamento com $\mathrm{GH}$ a curto e a longo prazo em crianças com

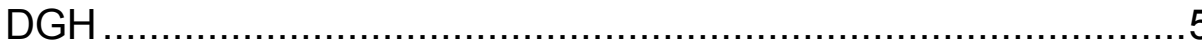

Quadro 2: Fatores envolvidos na replicabilidade variavel de estudos de associação genética 


\section{Resumo}

Costalonga EF. Farmacogenética do tratamento com hormônio de crescimento (GH) recombinante humano em crianças com deficiência de $\mathrm{GH}$ [tese]. São Paulo: Faculdade de Medicina, Universidade de São Paulo; 2010. 86p.

O hormônio de crescimento $(\mathrm{GH})$ recombinante humano $(\mathrm{rhGH})$ é o único tratamento disponível para crianças com deficiência de $\mathrm{GH}$ (DGH). Embora os resultados sejam em média satisfatórios, existe uma ampla variabilidade individual, de forma que alguns indivíduos ainda falham em atingir uma estatura normal ou dentro do seu potencial genético, mesmo quando diagnosticados e tratados sob as mesmas recomendações. Parte dessa variabilidade tem sido atribuída à falta de individualização da dose, uma vez que a terapia é baseada em doses fixas de rhGH ajustadas somente pelo peso. As variáveis clínicas preditivas de resposta ao tratamento com rhGH conhecidas até o momento explicam apenas $50 \%$ da variabilidade observada, sugerindo que outros parâmetros preditivos ainda estejam por ser reconhecidos. Apesar do intenso progresso de estudos moleculares, variáveis genéticas envolvidas na modulação da capacidade de resposta ao tratamento com rhGH permanecem amplamente desconhecidas. Sendo assim, o objetivo do presente estudo foi avaliar a influência de variantes gênicas comuns, presentes em genes envolvidos nos mecanismos de ação do $\mathrm{GH}$, sobre a capacidade de resposta de crescimento de crianças com DGH tratadas com $\mathrm{rhGH}$, de forma a fornecer ferramentas para a individualização do tratamento. Quatro polimorfismos de importância funcional presentes em três genes envolvidos nos mecanismos de ação do $\mathrm{GH}$ foram correlacionados à capacidade de resposta ao tratamento com rhGH em 84 crianças pré-púberes com DGH. Os achados moleculares foram correlacionados com a velocidade de crescimento no primeiro ano $(n=84)$ e com a altura ao final $(n=37)$ após tratamento com rhGH. As análises estatísticas foram ajustadas para as demais variáveis clínicas relacionadas à resposta ao tratamento com rhGH. Três desses polimorfismos - a presença (GHRfl) ou ausência (GHRd3) do exon 3 do gene do receptor de GH (GHR); as repetições $(C A) n$, da região promotora do gene do fator de crescimento insulina-símile -1 (IGF1); e o polimorfismo -202 A/C, da região promotora do gene da proteina transpostadora de IGF-3 (IGFBP3) - influenciaram de forma independente e interativa a capacidade de reposta ao tratamento com rhGH em crianças com DGH; enquanto que o polimorfismo p.Leu544lle do GHR não demonstrou influência sobre nenhum dos parâmetros analisados. Indivíduos portadores de pelo menos um alelo GHRd3 apresentaram maior altura final após tratamento com rhGH do que indivíduos homozigotos para o alelo GHRfl. Indivíduos homozigotos para o alelo de 19 repetições CA na região promotora do IGF1 demonstraram velocidade de crescimento no primeiro ano e altura final inferiores em relação aos indivíduos portadores de pelo menos um alelo alternativo. Finalmente, os homozigotos para o alelo IGFBP3 -202 A apresentaram maiores concentrações de IGFBP-3 sérica e maior velocidade de crescimento no primeiro ano de tratamento com rhGH 
do que indivíduos carreadores de pelo menos um alelo $C$ nesse mesmo locus. Embora estudos de validação sejam ainda necessários, acreditamos que as informações geradas por este e outros estudos - direcionados a um melhor entendimento das bases moleculares envolvidas na capacidade de resposta ao tratamento com rhGH - possam servir no futuro como importante ferramenta de individualização do tratamento com rhGH.

Descritores: 1.Farmacogenética 2.Medicina individualizada 3.Hormônio do crescimento/deficiência 4.Hormônio do crescimento humano/genética 5.Hormônio do crescimento humano/uso terapêutico 6.Receptores da somatotropina/genética 7.Fator de crescimento insulin -like I/genética 8.Proteínas de ligação a fator de crescimento insulin-like/genética 9.Polimorfismo genético/efeitos de drogas 


\section{Summary}

Costalonga EF. Growth hormone pharmacogenetics in children with growth hormone deficiency [thesis] "São Paulo: Faculdade de Medicina, Universidade de São Paulo”; 2010. 86p.

Recombinant human growth hormone $(\mathrm{rhGH})$ is the standard treatment for children with growth hormone deficiency (GHD). Although growth outcomes are usually satisfactory, there is a wide range of individual variability, so that some children do not achieve normal adult height or fail to reach final heights near their genetic potential, even when diagnosed and treated according to the same recommendation. Part of this variability has been attributed to the lack of treatment individualization, since therapy is based on fixed $\mathrm{rhGH}$ doses adjusted only by body weight. Clinical variables which predict growth responses to $\mathrm{rhGH}$ so far explain only $50 \%$ of the variability observed, suggesting that other influential factors may be missing from current prediction models. Despite the striking progress of molecular studies, genetic variables which are involved in modulation of $\mathrm{rhGH}$ responsiveness remain largely unknown. Thus, the aim of the present study was to evaluate the influence of common genetic variants present in genes involved in $\mathrm{GH}$ actions on the rhGH responsiveness of children with GHD. We assessed the influence of four functional polymorphisms in three genes involved in $\mathrm{GH}$ actions on treatment outcomes after $\mathrm{rhGH}$ treatment in 84 prepubertal children with GHD. Genotypes were correlated to first year growth velocity ( $\mathrm{n}$ $=84)$ and final height after treatment $(n=37)$. Statistical analyses were adjusted for other clinical influential factors. Our results demonstrated that three of these polymorphisms - the presence (GHRd3) or absence (GHRfl) of $\mathrm{GH}$ receptor (GHR) gene exon 3; the (CA)n repeats, in the insulin-like growth factor-1 (IGF1) promoter region; and the -202 A/C polymorphism, in the promoter region of insulin-like growth factor binding protein -3 (IGFBP3) gene - can independently and interactively influence the rhGH responsiveness of children with GHD. On the other hand, the p.Leu544lle variant of the GHR did not show any detectable influence. Individuals with at least one GHRd3 alelle had higher final height after $\mathrm{rhGH}$ treatment than individuals homozygous for the GHRfl allele. Homozygous for the IGF1 19 $\mathrm{CA}$ repeats allele presented lower first year growth velocity and lower final heights than those with at least one alternative IGF1 allele. Moreover, patients homozygous for the IGFBP3 -202 A allele presented higher IGFBP-3 serum levels and higher first year growth velocity than patients with at least one IGFBP3 C allele. Despite further validation studies are required, we believe that the results of this and other studies - directed to a better understanding of genetic basis of rhGH responsiveness - can be used, in the future, as important tools for rhGH treatment individualization.

Descriptors: 1.Pharmacogenetics 2.Individualized Medicine 3.Growth Hormone 4.Receptors, Somatomedin 5.Insulin-Like Growth Factor I 6.Insulin-Like Growth Factor Binding Proteins 7.Polymorphism, Genetic 
1 INTRODUÇÃO 
Na década de 50, o hormônio do crescimento (Growth Hormone, GH) obtido de hipófise de cadáver foi pela primeira vez utilizado para tratar a baixa estatura de crianças com deficiência de $\mathrm{GH}(\mathrm{DGH}){ }^{(1)}$. Na década de 80, com o advento do hormônio de crescimento recombinante humano (rhGH), houve um crescente aumento no uso deste hormônio para o tratamento de indivíduos com DGH assim como com outras causas de baixa estatura ${ }^{(2)}$. Hoje, cerca de 100.000 crianças são tratadas com rhGH em todo mundo ${ }^{(2,3)}$. Apesar da extensa experiência de 40 anos de uso, a estratégia terapêutica permanece amplamente inalterada: baseada em doses fixas ajustadas somente pelo peso ou superfície corpórea, sem levar em consideração os diferentes graus de sensibilidade individual $(3,4)$. Em crianças com DGH, a Growth Hormone Research Society recomenda que as doses variem entre 33 e $50 \mu \mathrm{g} / \mathrm{kg} / \mathrm{dia}{ }^{(5)}$, mas a dose exata que é habitualmente utilizada é determinada de forma empírica e arbitrária por cada serviço. Nos EUA, por exemplo, utiliza-se doses diárias entre 25 e $50 \mu \mathrm{g} / \mathrm{kg} / \mathrm{dia}$, enquanto na Europa as doses variam de 25 a $35 \mu \mathrm{g} / \mathrm{kg} / \mathrm{dia}$ e no Japão não ultrapassam $25 \mu \mathrm{g} / \mathrm{kg} / \mathrm{dia}^{(3,6)}$. Nesse contexto, embora os resultados obtidos sejam em média satisfatórios, observa-se uma ampla variabilidade do ponto de vista individual (Figura 1), de forma que alguns indivíduos ainda falham em atingir uma estatura normal e/ou dentro do seu 
potencial genético, mesmo quando diagnosticados e tratados sob as mesmas recomendações ${ }^{(2,4,7,8)}$.
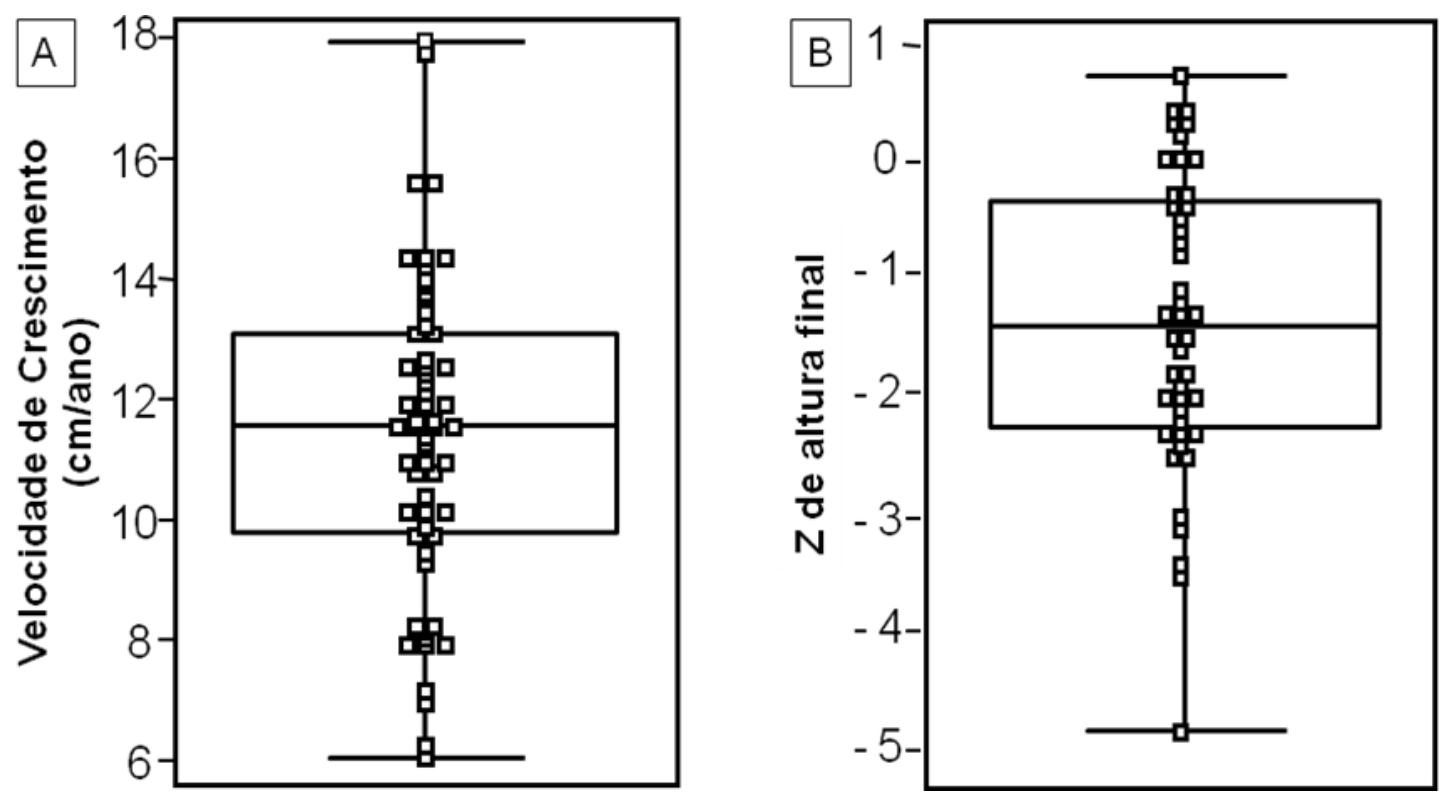

Figura 1: Variabilidade de respostas de crescimento em crianças com deficiência de $\mathrm{GH}$ tratadas com $\mathrm{GH}$ no serviço de Endocrinologia do Desenvolvimento do HC-FMUSP. A) Velocidade de crescimento no primeiro ano de tratamento (crianças exclusivamente pré-púberes). B) Escore-Z de altura final após tratamento com rhGH ${ }^{(9)}$

Nos últimos anos, tem havido uma progressiva mudança de paradigma na medicina, através da convergência da abordagem terapêutica tradicional - baseada em doses fixas - para uma terapêutica individualizada, com estratégias de conduta ajustadas ao perfil clínico e biológico de cada indivíduo ${ }^{(3,4,10)}$. A lógica primordial desse tipo de abordagem é que, a partir do conhecimento do grau de sensibilidade individual, pode-se definir qual a melhor droga a ser utilizada para determinado indivíduo ou ainda estabelecer um ajuste posológico desde o momento da instituição do 
tratamento $^{(11)}$. No caso da terapia com rhGH em indivíduos com DGH, em que não há tratamento alternativo disponível, a abordagem individualizada envolveria a determinação da dose mínima necessária à obtenção de resultados efetivos com redução dos custos e riscos ${ }^{(10)}$. No entanto, a fim de que essa abordagem seja possível, são necessárias ferramentas que permitam prever de forma acurada e objetiva o potencial de resposta de cada indivíduo.

Análises de regressão linear múltipla com informações coletadas de bancos de dados de um grande número de indivíduos tratados com rhGH têm sido utilizadas para o desenvolvimento de equações preditivas da resposta ao tratamento com $\mathrm{rhGH}$ a partir do uso combinado de diversas variáveis clínicas e laboratoriais envolvidas na determinação da capacidade de resposta ${ }^{(9,12-14)}$. No entanto, a aplicabilidade clínica desses chamados "modelos preditivos de resposta ao tratamento com rhGH" ainda não foi alcançada, o que pode ser atribuído a limitações tais como:

a) baixa capacidade preditiva, já que as variáveis identificadas até o momento (Quadro 1) explicam no máximo 40-60\% da variabilidade de resposta no primeiro ano de tratamento, e menos ainda em relação à altura final;

b) dependência de dados retrospectivos, tais como velocidade de crescimento no primeiro ano de tratamento e dados relativos ao início da puberdade - limitando dessa forma a instituição da individualização no momento do início do tratamento; e 
c) baixa precisão, resultando em valores preditivos com amplo desvio-padrão e, portanto, inadequados para a utilização como ferramentas de definição de conduta clínica.

Todas essas limitações evidenciam a importância de se buscar um aprimoramento dessa capacidade preditiva, o qual pode ser alcançado através da identificação de fatores influentes adicionais, tais como os genéticos.

Quadro 1: Fatores determinantes da capacidade de resposta ao tratamento com GH a curto e a longo prazo em crianças com DGH (revisados na ref. (9))

\begin{tabular}{|cc|}
\hline RESPOSTA A CURTO PRAZO & RESPOSTA A LONGO PRAZO \\
$\left(1^{\circ}\right.$ ANO) & (ALTURA FINAL)
\end{tabular}

- Pico de GH após estímulo

- Resposta de crescimento no $1^{\circ}$ ano

- Idade cronológica inicial

- Altura-alvo

- Z de altura inicial

- Pico de GH após estímulo

- Altura-alvo

- Z de altura inicial

- Dose de hGH utilizada

- Duração do tratamento

- $Z$ de peso inicial

- Idade cronológica inicial

- Z de peso ao nascer

- Sexo

- Número de injeções /semana.

- Puberdade espontânea ou induzida

- Idade do início da puberdade

- Altura do início da puberdade 


\subsection{Farmacogenética e estudos de associação genética}

Estudos dos últimos 50 anos têm evidenciado o papel determinante do background genético sobre a capacidade de resposta terapêutica e sensibilidade a efeitos adversos de diversos fármacos. A partir do crescente interesse pela busca de informações genéticas que permitissem a individualização terapêutica, houve o desenvolvimento de uma nova área da ciência, denominada farmacogenética, que se refere ao "estudo da contribuição da carga genética sobre as variações individuais de resposta a tratamentos farmacológicos" e ao "uso da informação genética para individualizar um tratamento" $(11,15,16)$.

A primeira referência à variabilidade de resposta terapêutica data de 510 a.C., quando Pitágoras observou intoxicação por determinadas favas em alguns indivíduos, mas não em outros. Dois mil e quinhentos anos depois, Alving e cols, em $1956^{(17)}$, demonstraram que a exposição a determinadas favas frescas (e também à primaquina, ao AAS, à fenacetina e às sulfonamidas) causava anemia hemolítica em pacientes com alteração da enzima glicose-6-fosfato desidrogenase, dessa forma inaugurando a era da farmacogenética ${ }^{(16,18)}$.

Embora haja alguns casos bem definidos como este, de variantes genéticas isoladas desempenhando efeitos pronunciados sobre a resposta a drogas (modelo monogênico), em geral essa resposta é produto de polimorfismos presentes em poucos (modelo oligogênico) ou múltiplos (modelos poligênico) genes que agem de forma interativa ${ }^{(18,19)}$. A maioria 
dessas variações confere impacto apenas modesto em nível individual, o que dificulta sua identificação através dos estudos genéticos clássicos, tais como estudos de linkage. Entretanto, por apresentarem freqüências de distribuição relativamente altas, podem apresentar efeito pronunciado em nível populacional ${ }^{(20-22)}$.

À semelhança do que ocorreu em relação aos estudos sobre a contribuição genética nas doenças de herança complexa, estudos de farmacogenética permaneceram durante muitos anos estagnados. Embora sua fundação conceitual tenha ocorrido há mais de 50 anos, o real progresso dessa área da ciência só se tornou possível a partir dos conhecimentos obtidos com o projeto genoma, resultando num crescimento geométrico do número de estudos publicados sobre o assunto nos últimos anos ${ }^{(16)}$.

Até o momento, a maioria dos estudos de farmacogenética tem utilizado os chamados estudos de associação genética ${ }^{(19,20,23-25)}$ para a identificação das variáveis genéticas envolvidas na determinação da variabilidade de respostas às medidas terapêuticas de interesse. Em geral, o primeiro passo destes estudos é a escolha da região do genoma a ser investigada. Embora estudos envolvendo todo genoma (whole genome scans) tenham o potencial de propiciar quebras de paradigmas - através da identificação de genes antes não previamente relacionados à característica estudada - por questões de custo-efetividade, a abordagem mais freqüentemente utilizada é a baseada em "genes candidatos". Essa estratégia se baseia na utilização dos conhecimentos de fisiologia, fisiopatologia ou estudos de linkage para a seleção dos genes mais provavelmente envolvidos 
na determinação do traço estudado, resultando, portanto, em menor custo financeiro e operacional de genotipagem, além de um menor "custo estatístico", por minimizar o efeito dos "múltiplos testes" sobre o poder estatístico do estudo ${ }^{(25,26)}$. No caso da farmacogenética, a escolha dos genes candidatos pode ser fundamentada tanto na farmacocinética (mecanismos de absorção, distribuição, metabolização e excreção) quanto na farmacodinâmica (mecanismo de ação no tecido alvo e cascata de sinalização) da medicação de interesse ${ }^{(16)}$.

Definidos os genes candidatos, uma ou mais variações de seqüência são utilizadas como marcadores genéticos para detectar a associação entre determinada região do genoma e a característica de interesse, tal como o perfil de resposta ao tratamento farmacológico. No entanto, é importante destacar que a presença de associação nem sempre implica em causalidade, já que os marcadores genéticos podem estar tanto diretamente relacionados à variabilidade observada (variante funcionalmente importante) quanto estar associados (em desequilíbrio de ligação - LD) a uma outra variante que não foi diretamente estudada, mas que é causativa ${ }^{(20,23-25)}$.

Os polimorfismos de base única (SNPs) são marcadores utilizados extensivamente nesses estudos devido à sua alta freqüência (cerca de 1 SNP a cada $300 \mathrm{pb}$ ) e da crescente facilidade de automatização na genotipagem. Os SNPs podem influenciar características fenotípicas através de inúmeros mecanismos, tais como: troca de aminoácido na proteína codificada, alteração de sítio de "splicing", alteração do nível de expressão da proteína, alteração da estabilidade do RNAm ou alteração da ação de microRNAs ${ }^{(27,28)}$. 
Com relação à seleção dos polimorfismos a serem estudados, uma metodologia comumente utilizada é a chamada "estratégia do polimorfismo candidato" em que poucos polimorfismos de importância funcional previamente descrita ou altamente provável são selecionados para estudo ${ }^{(19)}$. Apesar de ser uma estratégia altamente eficiente, esta nem sempre é possível, especialmente porque o número de polimorfismos de importância funcional conhecida é evidentemente inferior ao número de variações existentes. Assim, quando não há evidências de um possível "polimorfismo candidato" nos genes de interesse, ou simplesmente quando se pretende conhecer toda variabilidade comum de determinado gene, pode-se utilizar uma segunda estratégia que utiliza os chamados Tag SNPS, que são um conjunto de SNPs cuidadosamente escolhidos com base no padrão de desequilíbrio de ligação de determinada população, capazes de capturar a maior parte da variabililidade genética da região do genoma selecionada $(23,25,29)$. No presente estudo, optamos pela estratégia do polimorfismo candidato, uma vez que já haviam sido descritos polimorfismos comuns e de importância funcional nos genes de interesse, propiciando dessa forma uma melhor relação de custo efetividade no processo de investigação.

\subsection{Farmacogenética do tratamento com rhGH}

Apesar do intenso progresso dos estudos moleculares nas últimas

décadas e da clara influência genética sobre o crescimento humano ${ }^{(30,31)}$, variáveis genéticas envolvidas na modulação da capacidade de resposta 
ao tratamento com rhGH permanecem amplamente desconhecidas. Até recentemente, estas eram apenas indiretamente levadas em consideração, através da inclusão da altura-alvo nos modelos preditivos de resposta ao tratamento com $\mathrm{rhGH}^{(7,32,33)}$. Os primeiros trabalhos nesse sentido foram desenvolvidos nos últimos cinco anos e tiveram como objeto de estudo inicial o gene do receptor do $\mathrm{GH}(G H R)$, já que esta é a primeira molécula-chave envolvida na mediação das ações deste hormônio. Em 2004, foi demonstrado que um polimorfismo comum do GHR - a presença ou ausência do exon 3 - estava relacionado à capacidade de resposta ao tratamento com rhGH em indivíduos portadores de baixa estatura idiopática ou nascidos pequenos para idade gestacional ${ }^{(34)}$. Este trabalho inaugurou a era da farmacogenética do tratamento com rhGH e introduziu o importante conceito de que variações comuns em genes envolvidos no eixo GH - IGF1 podem desempenhar um papel na predição de resposta à terapia com rhGH.

Considerando-se que o conhecimento da base genética envolvida com a ampla variabilidade de respostas ao tratamento com rhGH pode contribuir para a construção de ferramentas úteis à individualização da terapia com rhGH, o objetivo do presente estudo foi avaliar a influência de polimorfismos comuns, de importância funcional previamente descrita, presentes em genes envolvidos com a ação do GH/IGF-1 sobre a resposta de crescimento obtida após tratamento com rhGH em crianças com DGH. 


\subsection{Mecanismos de ação do GH e eixo GH-IGF-1}

As ações do $\mathrm{GH}$ são mediadas por um receptor de membrana pertencente à superfamília dos receptores de citocinas, o GHR. A transdução do sinal intracelular é dependente da associação do receptor a uma proteína com atividade de tirosina quinase, conhecida como Janus quinase dois (JAK2). A ligação do $\mathrm{GH}$ aos receptores pré-dimerizados promove uma alteração na conformação espacial da porção intracitoplasmática do GHR, ativando a JAK2 e desencadeando a cascata de sinalização intracelular do GH. A STAT5b (Signal Transducer and Activators of Transcription 5b) é a principal proteína citoplasmática que medeia as ações do $\mathrm{GH}$, como o estímulo direto à proliferação celular ${ }^{(35)}$, a síntese de IGF-1, de sua proteína ligadora (IGFBP-3) e da subunidade ácido-lábil (ALS). A finalização do sinal via GHR é predominantemente mediada por proteínas da família SOCS (supressors of cytokine signaling), que consiste de pelo menos 8 membros CIS (cytokine inducible SH2-containing protein) e SOCS-1 a SOCS-7, dos quais os mais diretamente envolvidos com a sinalização do $\mathrm{GH}$ parecem ser SOCS 1,2,3 e CIS $^{(35)}$ (Figura 2).

Parte das ações promotoras de crescimento do $\mathrm{GH}$ são mediadas pela ação do IGF-1, o qual atua tanto por via endócrina quanto por via autócrina e parácrina. O IGF-1 presente na circulação e no fluido extracelular encontra-se ligado a uma família de proteínas transportadoras de alta afinidade, as IGFBPs (IGF-binding proteins). Atualmente, estão bem 
caracterizadas do ponto de vista molecular e bioquímico seis IGFBPs, denominadas IGFBP-1 a IGFBP-6. As IGFPBs regulam a disponibilidade dos IGFs para seus sítios de ação no receptor IGF-1R, além de apresentarem funções independentes sobre o crescimento celular ${ }^{(36)}$. No soro, $70-80 \%$ do IGF-1 circulante encontra-se na forma de um complexo ternário com a IGFBP-3 e a ALS, aproximadamente $20 \%$ encontra-se ligado a outras IGFBPs e menos de $5 \%$ é encontrado na forma livre ${ }^{(36-38)}$.

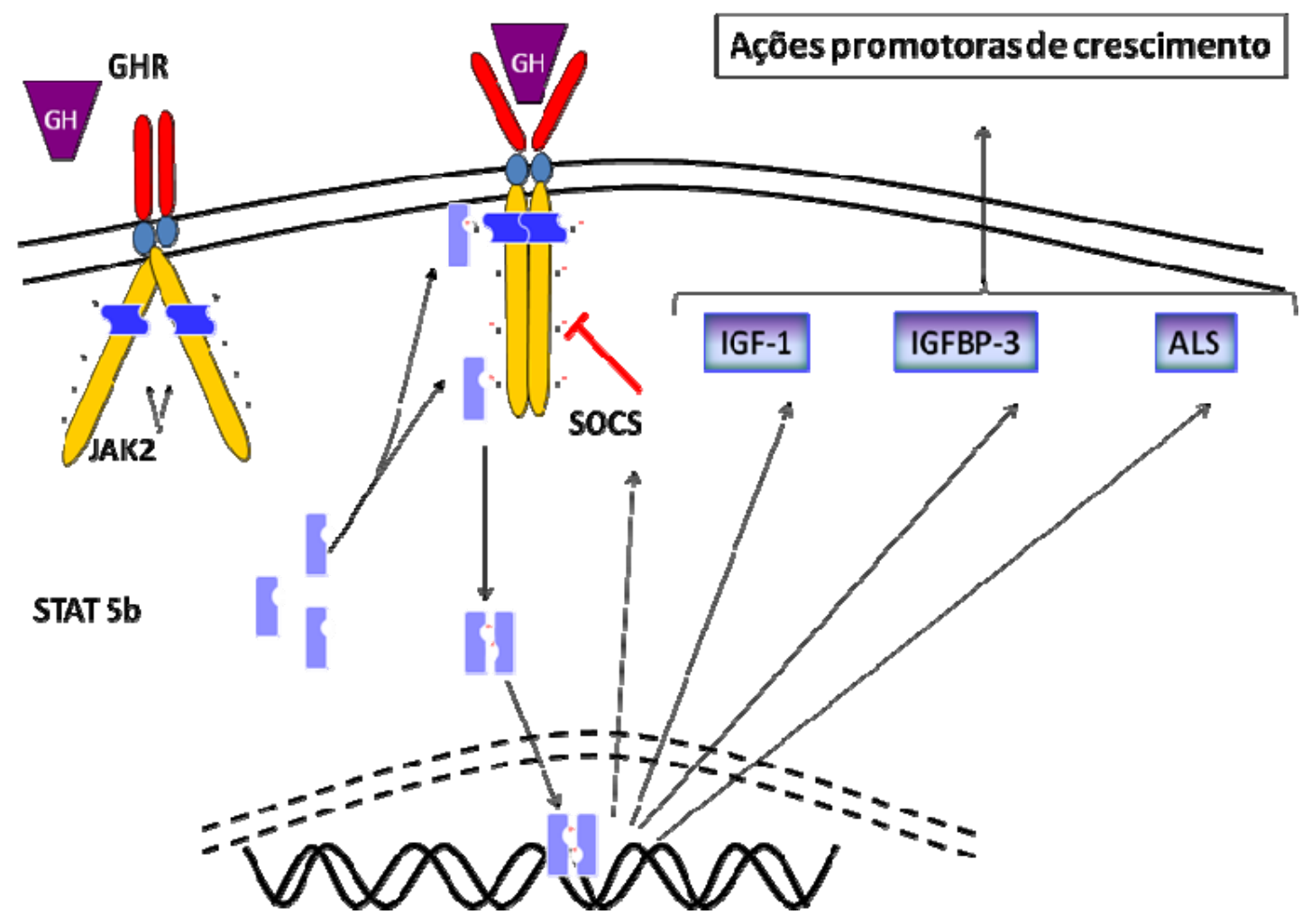

Figura 2: Esquema do mecanismo de transdução do sinal mediado por $\mathrm{GH}$ 


\subsection{Polimorfismos candidatos}

\subsubsection{Gene do Receptor do Hormônio do Crescimento (GHR)}

O GHR é codificado por um único gene localizado no cromossomo 5 no locus p13.1-p12, apresentando 87 kb de extensão. A região codificadora é composta pelos exons 2 a 10 . O exon 2 codifica os 11 pb finais da região 5' não traduzida, a seqüência que codifica 18 aminoácidos(aa) sinalizadores para o transporte intracelular da proteína e os 5 primeiros aminoácidos da porção extracelular do GHR. Os exons 3 ao 7 codificam a maior parte da porção extracelular do GHR (238 aa, que correspondem ao domínio de ligação do hormônio ao receptor). O exon 8 codifica os 3 últimos aminoácidos do domínio de ligação do hormônio, os 24 aa hidrofóbicos que compõem o domínio transmembrânico e os 4 primeiros aminoácidos do início da porção intracelular. Os exons 9 e 10 codificam os 346 aa restantes do domínio intracelular, essenciais para a transdução do sinal; e o exon 10 também codifica a seqüência 3' não traduzida do $\operatorname{GHR}^{(35,39)}$ (Figura 3).

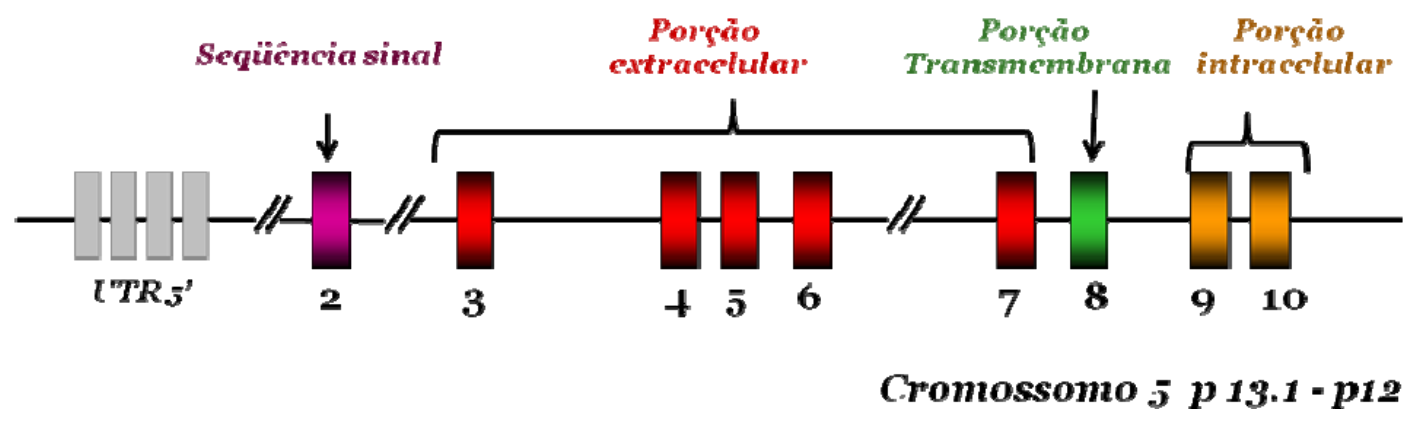

Figura 3: Representação esquemática da estrutura do gene do GHR 
Para o presente estudo, foram selecionados dois polimorfismos desse gene: a presença ou ausência do exon 3 - que participa da codificação da porção extracelular do receptor - e o SNP não sinônimo p.Leu544lle localizado no exon 10, o qual participa da codificação da porção intracelular, envolvida com a transdução do sinal mediada por $\mathrm{GH}$.

\subsubsection{Presença ou ausência do exon 3 do GHR}

A ausência do exon 3 é um polimorfismo comum do GHR, sendo que, na população caucasiana, cerca de $43 \%$ dos indivíduos são homozigotos para o GHR full length (GHRfl/fl), 12\% são homozigotos para GHR com exon 3 deletado (GHRd3/d3) e 46\% são heterozigotos $(G H R f l / d 3){ }^{(40-44)}$. Embora estudos iniciais tenham documentado um padrão de expressão tecido específico, evidências subseqüentes demonstraram que a expressão dessas duas isoformas de GHR é específica para cada indivíduo e transmitida como um traço mendeliano ${ }^{(45)}$. O mecanismo de origem das duas isoformas foi revelado por Pantel e cols., que demonstraram que a perda do exon 3 resultava de um processo de recombinação homóloga entre duas sequências retrovirais flanqueadores desse exon que ocorreu exclusivamente em humanos ${ }^{(43)}$.

O GHR gerado pelo alelo GHRd3 apresenta deleção de 22 aminoácidos, além da substituição do aminoácido ácido aspártico por alanina (conservado em espécies de mamíferos) na região amino-terminal do receptor, correspondente ao domínio de ligação ao $\mathrm{GH}{ }^{(43)}$. Estes aminoácidos não participam diretamente na ligação do hormônio 
ao receptor, de forma que ambas as isoformas, GHRfl e GHRd3, ligam-se ao $\mathrm{GH}$ com afinidades similares ${ }^{(46)}$. Por outro lado, estudos funcionais demonstraram que células transientemente transfectadas com GHRd3 induzem transdução do sinal após tratamento com GH 30\% superior ao de células transfectadas com GHRfl ${ }^{(34)}$. Não houve diferença na atividade transcricional observada entre as células transfectadas com GHRd3 isolado ou associado ao GHRfl, sugerindo efeito dominante do alelo GHRd3.

Dos Santos e col., em 2004, estudando dois coortes independentes de crianças nascidas pequenas para a idade gestacional ou com baixa estatura idiopática (totalizando 172 crianças), tratadas com doses semelhantes de $\mathrm{rhGH}$, demonstraram que pacientes portadores de pelo menos um alelo GHRd3 apresentavam incremento na velocidade de crescimento durante o primeiro e segundo anos de tratamento com rhGH de 2 a $3 \mathrm{~cm} /$ ano superior ao dos pacientes homozigotos para o alelo GHRfl $(p<0,0001)$. O genótipo em relação ao exon 3 foi o principal fator preditivo de resposta ao tratamento com rhGH após ajuste para sexo, idade de início de tratamento e dose ${ }^{(34)}$.

Em 2006, nosso grupo avaliou a influência desse mesmo polimorfismo sobre a resposta ao tratamento com $\mathrm{rhGH}$ de pacientes com $\mathrm{DGH}$ bem caracterizada. Pacientes homozigotos para o alelo GHRfl apresentaram menor velocidade de crescimento e menor ganho de altura no primeiro ano de tratamento, assim como menor altura final ao término do tratamento, quando comparados com pacientes carreando pelo menos um alelo GHRd3. 
A diferença média de altura final em escores de desvios padrão entre os dois grupos foi de 0,9 , favorecendo os pacientes carreadores de pelo menos um alelo GHRd3 ${ }^{(47)}$. Embora os resultados de estudos posteriores não tenham sido uniformes quanto a essas observações, uma série de estudos envolvendo esse polimorfismo em diferentes condições clínicas apontam para evidências de uma maior sensibilidade ao $\mathrm{GH}$ na presença do alelo GHRd3 (Tabela 1) ${ }^{(48-50)}$. Além disso, uma metanálise recente evidenciou a presença de uma influência pequena mas significativa do genótipo GHR-exon3 sobre a velocidade de crescimento no primeiro ano de tratamento de indivíduos com DGH tratados com rhGH ${ }^{(51)}$.

Desta forma, incluímos o estudo desse polimorfismo em nosso trabalho, sobretudo a fim de avaliar de que forma o mesmo poderia atuar de forma interativa com as demais variações genotípicas comuns selecionadas. 
Tabela 1: Apresentação resumida dos trabalhos que avaliaram a influência do genótipo GHR-exon3 sobre diferentes parâmetros de sensibilidade ao GH

\begin{tabular}{|c|c|c|c|}
\hline Autor & Ano & Parâmetro & $\begin{array}{l}\text { Efeito do } \\
\text { alelo GHRd3 }\end{array}$ \\
\hline \multicolumn{4}{|c|}{ Crianças com DGH tratadas com rhGH } \\
\hline Jorge e cols. ${ }^{(47)}$ & 2006 & VC $1^{\circ}$ ano e Altura final & Positivo \\
\hline Blum e cols. ${ }^{(48)}$ & 2006 & $\mathrm{VC} 1^{\circ}$ ano & Neutro \\
\hline Pilotta e cols. ${ }^{(50)}$ & 2006 & $\mathrm{VC} 1^{\circ}$ ano & Neutro \\
\hline \multirow[t]{2}{*}{ Raz e cols. ${ }^{(40)}$} & 2008 & $\mathrm{VC} 1^{\circ}$ ano & Positivo \\
\hline & & Altura final & Neutro \\
\hline Marchisotti e cols. ${ }^{(52)}$ & 2009 & Incremento de IGF-1 & Positivo \\
\hline Wassenaar e cols. ${ }^{(51)}$ & 2009 & VC $1^{\circ}$ ano (metanálise) & Positivo \\
\hline \multicolumn{4}{|c|}{ Crianças com Síndrome de Turner tratadas com rhGH } \\
\hline Binder e cols. ${ }^{(42)}$ & 2006 & $\mathrm{VC} 1^{\circ}$ ano & Positivo \\
\hline Binder e cols. ${ }^{(53)}$ & 2007 & Altura final & Positivo \\
\hline \multicolumn{4}{|c|}{ Crianças nascidas PIG tratadas com rhGH } \\
\hline Dos Santos e cols. ${ }^{(34)}$ & 2004 & $\mathrm{VC} 1^{\circ}$ ano & Positivo \\
\hline Carrascosa e cols. ${ }^{(49)}$ & 2006 & $\mathrm{VC} 1^{\circ}$ ano & Neutro \\
\hline \multicolumn{4}{|c|}{ Crianças com baixa estatura idiopática tratadas com rhGH } \\
\hline Dos Santos e cols. ${ }^{(34)}$ & 2004 & $\mathrm{VC} 1^{\circ}$ ano & Positivo \\
\hline Tauber e cols. ${ }^{(41)}$ & 2007 & $\mathrm{VC} 1^{\circ}$ ano & Positivo \\
\hline Min Ko e cols. ${ }^{(54)}$ & 2009 & $\mathrm{VC} 1^{\circ}$ ano & Positivo \\
\hline Toyoshima e cols. ${ }^{(55)}$ & 2007 & Teste de geração de IGF-1 & Positivo \\
\hline \multicolumn{4}{|c|}{ Adultos com DGH tratados com rhGH } \\
\hline Van der Klaauw e cols. ${ }^{(56)}$ & 2008 & Aumento de IGF1 & Positivo \\
\hline Barbosa e cols. $^{(57)}$ & 2009 & Aumento de IGF1 & Neutro \\
\hline \multicolumn{4}{|l|}{ Adultos com Acromegalia } \\
\hline Schmid e cols. ${ }^{(58)}$ & 2007 & $\begin{array}{l}\text { Concentração de IGF-1 } \\
\text { por concentração de GH }\end{array}$ & Positivo \\
\hline Mercado e cols. ${ }^{(59)}$ & 2008 & $\begin{array}{l}\text { Normalização do IGF1 } \\
\text { com tratamento }\end{array}$ & Positivo \\
\hline Bianchi e cols. ${ }^{(60)}$ & 2008 & Resposta ao tratamento & Positivo \\
\hline Bernabeu e cols. ${ }^{(61)}$ & 2010 & com pegvisomant & Positivo \\
\hline
\end{tabular}




\subsubsection{Polimorfismo p. Ile544Leu do GHR}

A porção intracelular do GHR, onde há interação do receptor com a JAK2 e STAT5b, é codificada pelos exons 9 e 10. Por isso, essa região foi extensivamente estudada em busca de mutações que pudessem estar relacionadas ao fenótipo de resistência ao $\mathrm{GH}$ ou de baixa estatura idiopática ${ }^{(62)}$. Nesses trabalhos, foram identificadas algumas variantes genéticas, que posteriormente foram definidas como polimorfismos presentes na população geral. Um deles (hCV2841422; rs6180), localizado no exon 10, constitui-se da troca de uma adenosina por uma citosina no códon 544 do GHR (ATC >CTC) que resulta na substituição de uma isoleucina por uma leucina na proteína (p. Ile544Leu). A importância funcional desse polimorfismo foi sugerida por dois estudos prévios. Um deles, estudando 95 indivíduos portadores de mutação do receptor de LDL (hipercolesterolemia familiar), demonstrou que os níveis de HDL eram menores nos indivíduos homozigotos para leucina e aumentavam de maneira progressiva na presença de um ou dois alelos codificadores de isoleucina ${ }^{(63)}$. O segundo estudo demonstrou que meninos com DGH homozigotos para isoleucina apresentavam maiores níveis de colesterol total, antes e após tratamento com rhGH ${ }^{(64)}$. Dessa forma, este polimorfismo foi selecionado para o estudo atual, uma vez que constitui variação comum na nossa população, que resulta na troca de aminoácido em região envolvida na transdução do sinal mediada por GHR e com importância funcional clinicamente sugerida por outros estudos. 


\subsubsection{Gene do Fator de Crescimento Insulina Símile-1 (IGF1)}

O IGF-1 é o principal peptídeo mediador das ações do $\mathrm{GH}$, desempenhando um importante papel estimulatório sobre o crescimento. Embora $75 \%$ do IGF-1 circulante seja derivado do fígado, estudos recentes demonstram que tanto o IGF-1 derivado do fígado quanto o produzido localmente podem estimular o crescimento longitudinal ${ }^{(65)}$. Além disso, há evidências de que as concentrações séricas de IGF-1 sofram importante determinação genética, já que estudos em gêmeos demonstraram concordância de até $91 \%$ entre os monozigóticos, enquanto que entre os dizigóticos a concordância não ultrapassa os $40 \%{ }^{(66,67)}$.

Dessa forma, podemos antever que variações genéticas envolvidas na capacidade de expressão e, portanto, na determinação das concentrações séricas e/ou locais de IGF-1 possam apresentar influência sobre a capacidade de resposta ao tratamento com rhGH.

\subsubsection{Microssatélite (CA)n da região promotora do IGF1}

O gene do IGF-1 está localizado no braço longo do cromossomo 12 (12q 22-23), é constituído por 6 exons e mede 85 kb. Desde 1998, um polimorfismo situado na região promotora desse gene tem sido implicado na regulação genética das concentrações séricas da proteína ${ }^{(68)}$. Trata-se de um microssatélite representado por uma seqüência de tamanho variável de repetições citosina-adenosina $(\mathrm{CA})$, altamente polimórfico, localizado cerca de 1 Kb antes do sítio de início da transcrição (D12S0043i; UniSTS 49688). 
O número de repetições $C A$ varia entre 10 e 24. Conforme o número de repetições e o tamanho da sequência amplificada correspondente, foram identificados 10 diferentes alelos $(182,184,186,188,190,192,194,196$, 198, $200 \mathrm{pb})^{(69)}$. Estudos em populações caucasianas demonstraram que cerca de $60 \%$ dos indivíduos são portadores de pelo menos um alelo de 19 repetições CA (correspondente a fragmentos de 192 pb após amplificação padronizada), sugerindo que este é o alelo wild-type ${ }^{(68,70)}$.

Inúmeros estudos avaliaram a influência deste polimorfismo sobre as concentrações séricas de IGF-1 em adultos ${ }^{(68,71-73)}$ e sobre diversas variáveis relacionadas às ações deste hormônio, tais como: comprimento e peso ao nascer ${ }^{(73,74)}$, estatura adulta ${ }^{(70,75,76)}$, densidade mineral óssea ${ }^{(77)}$, distribuição de gordura corporal ${ }^{(78)}$, risco de câncer ${ }^{(79,80)}$, risco de DM ${ }^{(76)}$ e risco de microalbuminúria em diabéticos tipo $1^{(81)}$. Dadas as evidências clínicas da importância funcional desse polimorfismo, consideramos que este genótipo possa estar relacionado ao componente geneticamente determinado do potencial de resposta ao tratamento com rhGH.

\subsubsection{Gene da Proteína Transportadora de IGFs - 3 (IGFBP3)}

Adicionalmente ao fato de ser a principal proteína transportadora de

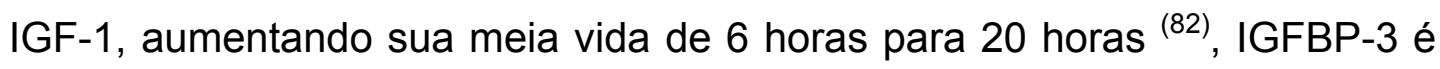
capaz de modular as ações de IGF-1 em nível tecidual, além de apresentar efeitos sobre a proliferação celular de forma independente de IGF-1 ${ }^{(36-38,83)}$. O gene da IGFBP-3 é altamente conservado entre as espécies e está 
presente como uma cópia simples no cromossomo 7p14-p12. Estudos em gêmeos demonstram que cerca de $60 \%$ da variabilidade interindividual dos níveis séricos de IGFBP-3 sejam geneticamente determinados ${ }^{(67)}$.

Considerando-se que a modulação genética da produção de IGFBP-3 poderia determinar influência sobre as concentrações séricas e as ações locais de IGF-1, este também foi considerado um gene candidato para estudos de farmacogenética do rhGH.

\subsubsection{Polimorfismo -202 A/C da região promotora do IGFBP3}

Em 2001, Deal e cols identificaram uma série de polimorfismos na região promotora do IGFBP3. Entre esses, o mais comum e relevante (rs2854744) constitui-se de uma variante (citosina ou adenosina) localizada 202 pb antes do sítio de início da transcrição, próximo a elementos que presumivelmente controlam a atividade promotora basal do gene. Demonstrou-se que a variação genotípica nesse locus estava altamente relacionada às concentrações séricas de IGFBP-3 em 478 adultos normais do sexo masculino, sendo que as concentrações médias eram maiores nos indivíduos homozigotos para o alelo $\mathrm{A}$ e declinavam significantemente na presença e 1 ou 2 cópias do alelo C. Além disso, esses mesmos autores evidenciaram, através de estudos in vitro com duas linhagens celulares diferentes, que a atividade transcricional de sequências apresentando o alelo A era cerca de $50 \%$ superior à do alelo C, de forma coerente com os achados clínico-laboratoriais ${ }^{(84)}$. Após este primeiro estudo, inúmeros outros demonstraram a influência desse 
mesmo polimorfismo sobre as concentrações séricas de IGFBP-3 em adultos ${ }^{(85-91)}$, confirmando os achados iniciais e suportando a importância funcional desse polimorfismo.

Até o início deste trabalho, não havia dados na literatura sobre a influência dessa variante genética comum sobre as concentrações séricas de IGFBP-3 em crianças, e muito menos sobre a correlação deste com a resposta ao tratamento com $\mathrm{rhGH}$; dessa forma motivando a inclusão do mesmo no presente estudo. 
2 OBJETIVOS 
Correlacionar a presença de quatro polimorfismos presentes em genes envolvidos nos mecanismos de ação do GH / IGF-1 (GHR, IGF1 e IGFBP3) com a resposta ao tratamento com rhGH em crianças com DGH. 
3 MÉTODOS 


\subsection{Considerações éticas}

Este estudo foi conduzido de acordo com princípios éticos seguindo as orientações contidas na declaração de Helsinki. Consentimento por escrito foi obtido de todos os pacientes ou pais/tutores antes que os procedimentos de pesquisa fossem iniciados. O protocolo de estudo foi submetido ao comitê de ética da instituição e aprovado (número de protocolo de pesquisa na CAPPesq: 847/06).

\subsection{Casuística}

Dados clínicos, auxológicos, laboratoriais e referentes ao regime terapêutico de 134 indivíduos portadores de DGH acompanhados na Unidade de Endocrinologia do Desenvolvimento do Hospital das Clínicas da FMUSP (n=104), na Faculdade de Medicina da Universidade de São Paulo de Riberão Preto $(n=19)$ ou na Universidade Estadual de Campinas UNICAMP $(n=11)$ foram coletados e informatizados para análise. No intuito de se obter a maior homogeneidade possível da amostra, optamos por incluir no estudo apenas indivíduos portadores de DGH grave, os quais foram selecionados segundo os seguintes critérios: 


\section{Critérios de Inclusão:}

- Diagnóstico de deficiência de GH completa, definida por ausência de resposta em dois testes de estímulo do $\mathrm{GH}$ (pico de $\mathrm{GH}<5,0 \mu \mathrm{g} / \mathrm{l}$ (IRMA / IQMA) ou $<3,3 \mu \mathrm{g} / \mathrm{l}\left(\right.$ IFMA) $^{(92)}$

- Uso de hormônio do crescimento recombinante humano (rhGH) durante todo o tratamento da $\mathrm{DGH}$ em esquema de reposição subcutânea diária.

- Reposição adequada dos demais hormônios hipofisários (quando indicada).

\section{Critérios de Exclusão:}

- Doenças crônicas concomitantes.

- DGH de etiologia secundária à presença de tumores de SNC, meningomielocele, cirurgia hipofisária ou radioterapia.

- Início da puberdade anterior ao tratamento ou até o final do primeiro ano de tratamento com rhGH

- Informações relativas ao período de tratamento insuficientes para análise estatística multivariada.

Dos 134 pacientes avaliados, foram finalmente selecionados 63 indivíduos provenientes do HC-FMUSP, 12 da USP-RP e 9 da UNICAMP (total de 84 indivíduos). Todos os indivíduos selecionados $(n=84)$ foram avaliados quanto à resposta de crescimento à terapia com rhGH a curto prazo, refletida pela sobretudo pela velocidade de crescimento (VC) no 
primeiro ano de tratamento. Entre estes, 37 indivíduos atingiram a estatura final ou quase final (definida por $V C<2 \mathrm{~cm} / a n o$ no último ano de tratamento) após um período mínimo de 3 anos de tratamento, sendo portanto selecionados para avaliação da resposta de crescimento a longo prazo ( $Z$ altura final ajustado para o $Z$ da altura-alvo).

\subsection{Protocolo de acompanhamento clínico}

O diagnóstico de $\mathrm{DGH}$ foi baseado em dados clínicos e auxológicos e na ausência de resposta do $\mathrm{GH}$ em pelos menos dois testes provocativos (principalmente clonidina e insulina). Todos pacientes foram submetidos a ressonância nuclear magnética da região hipotálamo-hipofisária. De acordo com os níveis basais e após teste provocativo combinado (Insulina + TRH + $\mathrm{GnRH}$ ), os pacientes foram classificados quanto à presença de $\mathrm{DGH}$ isolada (DGHI) ou combinada a outras deficiências hipofisárias (DGHC). Pacientes apresentando DGHC receberam reposição adequada das demais deficiências hormonais.

rhGH foi administrado por via subcutânea numa dose média de $33 \mu \mathrm{g} / \mathrm{kg} / \mathrm{d}(0.1 \mathrm{UI} / \mathrm{kg} / \mathrm{d})$, a qual era ajustada de acordo com mudanças no peso a cada consulta e frequentemente aumentada para $50 \mu \mathrm{g} / \mathrm{kg} / \mathrm{d}$ $(0,15 \mathrm{Ul} / \mathrm{kg} / \mathrm{d})$ durante o período de puberdade. Todos os indivíduos foram avaliados antes do tratamento e a cada 3-4 meses durante a terapia de reposição. A velocidade de crescimento no primeiro ano de tratamento foi 
determinada após um período de observação de pelo menos 11 meses. Entre os indivíduos que completaram o crescimento, a altura final foi determinada, em média, 1,4 anos após a suspensão do rhGH.

As avaliações foram feitas sempre pela manhã e incluíam medidas de peso (medido por balança digital) e altura de pé (determinada com um estadiômetro, através da média de 3 medidas seguidas). Altura e índice de massa corpórea foram expressos na forma de escores de desviopadrão $(Z)^{(93)}$. A altura-alvo foi calculada [(altura do pai + altura da mãe+13 para meninos ou -13 para meninas) / 2] e também expressa na forma de escore-Z. Raios X de mão e punho esquerdo foram obtidos para determinação de idade óssea e avaliados pelo método de Greulich and Pyle ${ }^{(94)}$. As concentrações séricas de IGF-1 e IGFBP-3 foram medidas antes e durante o tratamento.

\subsection{Dosagens hormonais}

O GH foi medido pelos métodos imunorradiométrico (IRMA) (54\% dos pacientes), imunofluorimétrico (IFMA) com anticorpos monoclonais (AutoDELFIA, Wallac, Turku, Finland) (36 \% dos pacientes) ou por quimioluminescência (10\% dos pacientes).

As concentrações de IGF-1 foram obtidas no início do tratamento e próximo ao final do primeiro ano de tratamento em 54 e $67 \%$ dos pacientes, respectivamente. As medidas foram obtidas através de radioimunoensaio 
após extração com etanol (Diagnostic Systems Laboratories - DSL, Webster, TX) em $85 \%$ dos pacientes e por quimioluminescência (IMMULITE, Diagnostic Products Corporation - DPC, Los Angeles, CA) em 15\% dos pacientes. As concentrações de IGFBP-3 foram obtidas no início do tratamento e próximo ao final do primeiro ano de tratamento em 40 e $60 \%$ dos pacientes, respectivamente. As medidas foram obtidas através de radioimunoensaio (Diagnostic Systems Laboratories - DSL, Webster, TX) em $79 \%$ dos pacientes e por quimioluminescência (IMMULITE, Diagnostic Products Corporation - DPC, Los Angeles, CA) em $21 \%$ dos pacientes.

Os valores de IGF-1 e IGFBP-3 foram expressos como Z-escore em relação aos padrões de normalidade para sexo e idade fornecidos pelos respectivos kits.

\subsection{Coleta de dados para análises multivariadas}

Todos os registros médicos dos pacientes avaliados foram verificados para a coleta de dados referentes a sexo; altura dos pais; pico de $\mathrm{GH}$ em testes de estímulo; presença de outras deficiências hipofisárias; etiologia da DGH; idade cronológica, idade óssea, altura, peso e estadio puberal no início e no final do primeiro ano de tratamento; data de início da puberdade; doses de rhGH utilizadas ao longo do tratamento; duração do tratamento; altura final, IGF-1 e IGFBP-3 antes e durante o tratamento. 


\subsection{Estudos Moleculares}

\subsubsection{Preparação das amostras- extração de DNA genômico}

As amostras de DNA foram obtidas a partir de leucócitos de sangue periférico dos indivíduos arrolados na pesquisa. Dez mililitros de sangue venoso foram colhidos em ácido etileno diaminotetracético (EDTA 25 mM). O botão leucocitário foi obtido a partir da lise dos glóbulos vermelhos utilizando-se um volume de solução de lise $\left(\mathrm{NH}_{4} \mathrm{Cl}\right.$ a $114 \mathrm{mM}, \mathrm{NH}_{4} \mathrm{HCO}_{3}$ a $1 \mathrm{mM}$ ) duas vezes maior que o volume de sangue, incubado a $4^{\circ} \mathrm{C}$ por 30 minutos. $\mathrm{O}$ material foi centrifugado a $4^{\circ} \mathrm{C}$ durante 15 minutos a $4000 \mathrm{~g}$ (Sorvall, RT7, Germany), sendo desprezado o sobrenadante. O procedimento da lise de glóbulos vermelhos foi repetido uma vez.

O botão de células brancas foi suspenso em nove ml de solução de lise de glóbulos brancos ( $\mathrm{NaCl} 150$ mM, Tris-HCl 10 mM, pH 8,0; EDTA $10 \mathrm{mM} \mathrm{pH}$ 8,0) com $180 \mu \mathrm{L}$ de dodecilsulfato de sódio a $10 \%$ (SDS) (Sigma, St. Louis, MO, USA) e $150 \mu \mathrm{L}$ de proteinase $\mathrm{K}$ na concentração de $10 \mathrm{mg} / \mathrm{ml}$ (Gibco BRL, Gaithersburg, MD, USA), e incubado a $37^{\circ} \mathrm{C}$ por 18 horas. Após este período, 3,6 ml de solução saturada de $\mathrm{NaCl}$ a $6 \mathrm{M}$ foi adicionada, seguido de agitação do conjunto vigorosamente durante 15 segundos. O material foi centrifugado por 15 minutos a $4000 \mathrm{~g}$. O sobrenadante foi transferido para outro tubo e o DNA foi precipitado acrescentando-se dois volumes de etanol absoluto gelado, homogeneizando-se cuidadosamente por inversão. O DNA precipitado foi 
retirado do tubo, em seguida lavado em etanol a $70 \%$ durante 5 minutos, repetindo-se a operação por mais três vezes. Finalmente, o DNA foi lavado em etanol absoluto, seguido de secagem por centrifugação a vácuo (Eppendorf, Concentrator 5301, Germany). Após o procedimento, o DNA foi ressuspenso em tampão TE a 10:0,1 (Tris- $\mathrm{HCl} 10 \mathrm{mM}, \mathrm{pH}$ 8,0; EDTA $0,1 \mathrm{mM}, \mathrm{pH} 8,0)$.

\subsubsection{Metodologias de genotipagem}

\subsubsection{Presença ou ausência do exon 3 do GHR}

Para a genotipagem dos indivíduos quanto à distribuição dos alelos GHRfl e GHRd3, utilizamos a metodologia descrita por Pantel e col.(43), que consiste na realização de uma reação de polimerização em cadeia (PCR) multiplex - envolvendo três primers, um primer sense (G1: 5'-TGTGCTGGTCTGTTGGTCTG-3') e dois primers antisense (G2: 5'-AGTCGTTCCTGGGACAGAGA-3' e G3: 5'-CCTGGATTAACACTTTGCAGACTC-3') que flanqueiam a região do exon 3. Foi utilizado o seguinte programa de amplificação: denaturação inicial a $94^{\circ} \mathrm{C}$ por 5 minutos seguido por 35 ciclos de denaturação à $94^{\circ} \mathrm{C}$ por 30 segundos, hibridização a $60^{\circ} \mathrm{C}$ por 30 segundos e extensão a $72^{\circ} \mathrm{C}$ por 1,5 minuto e no último ciclo 7 minutos a $72{ }^{\circ} \mathrm{C}$ para extensão final. As amostras amplificadas foram avaliadas em gel de agarose a $1 \%$ contendo brometo de etídio e observadas em transiluminador ultravioleta. Os primers G1 e G2 são específicos para amplificação do fragmento que 
apresenta deleção do exon 3 e geram um produto de PCR com 532pb (GHRd3) e os primers G1 e G3 apenas amplificam os alelos que possuem o exon 3 resultando em um produto de PCR com 935pb (GHRfl) (Figura 4).
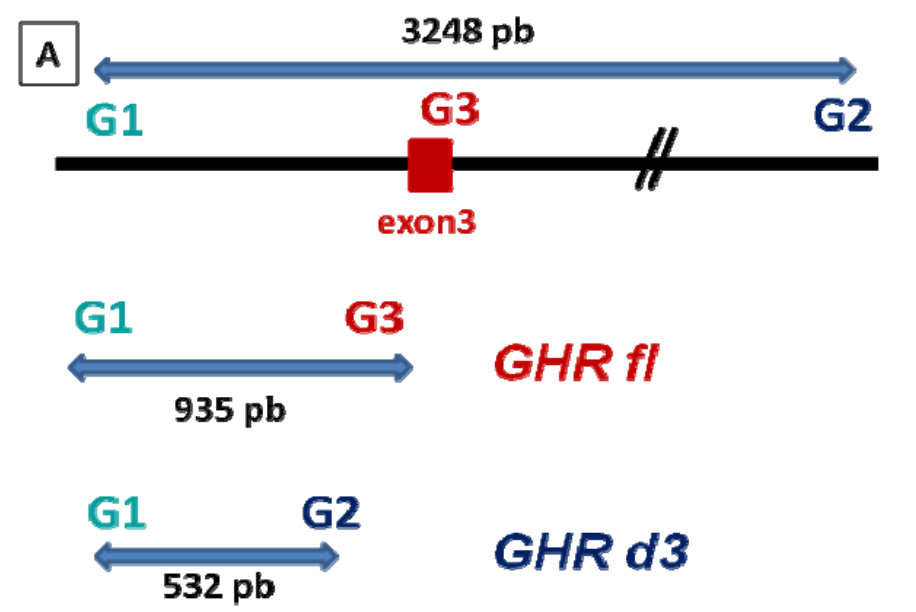

GHR d3

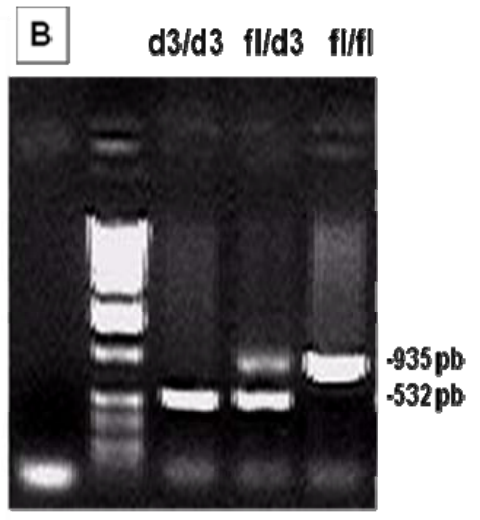

Figura 4: PCR multiplex para genotipagem da presença ou ausência do exon 3 do $G H R$ : A) Representação esquemática da região do $\mathrm{GHRfl}$, contendo exon 3. Os primers $\mathrm{G} 1$ e G2 são específicos para amplificação do fragmento que apresenta deleção do exon 3 e geram um produto de PCR com 532pb (GHRd3) e os primers G1 e G3 apenas amplificam os alelos que possuem o exon 3 resultando em um produto de PCR com 935pb (GHRfl). B) Foto de gel de agarose contendo produtos de PCR dos três possíveis genótipos (adaptado de Pantel e cols. ${ }^{(43)}$ )

\subsubsection{Polimorfismo p. Ile544Leu do GHR}

Para a genotipagem deste polimorfismo, inicialmente realizamos uma reação de PCR utilizando primers flanqueadores da região (sense: 5' GAGTTTCTTTTCATAGATCTTCATTTTC 3' e antisense: 5' GGTTTAAACATTGTTTTGGC 3') e o seguinte programa de amplificação: denaturação inicial a $95^{\circ} \mathrm{C}$ por 5 minutos seguido por 35 ciclos de denaturação a $94^{\circ} \mathrm{C}$ por $1 \mathrm{~min}$, hibridização a $55^{\circ} \mathrm{C}$ por 1 min, extensão a 
$72^{\circ} \mathrm{C}$ por 1 minuto e extensão final a $72{ }^{\circ} \mathrm{C}$ por 10 minutos. Todas as reações foram acompanhadas de um controle negativo (todos os reagentes, exceto o DNA). A reação originava fragmentos de $1101 \mathrm{pb}$, que foram a seguir submetidos à técnica de digestão enzimática utilizando-se $1 \mathrm{UI}$ da enzima de restrição $\mathrm{HpyCH} 4 \mathrm{~V}$, a $37^{\circ} \mathrm{C}$, por 3 horas. Um controle de reação, ao qual não era adicionada a enzima, era incluído no experimento. Os produtos da digestão eram a seguir submetidos a uma eletroforese em gel de agarose a $2 \%$ em tampão TAE e os fragmentos de DNA visualizados em luz ultravioleta após coloração com brometo de etídio. Alelos C (correspondentes ao aminoácido leucina) originavam fragmentos de 645 e $456 \mathrm{pb}$, enquanto que os alelos A (correspondentes ao aminoácido isoleucina) originavam fragmentos de 645,376 e 80 pb (Figura 5).

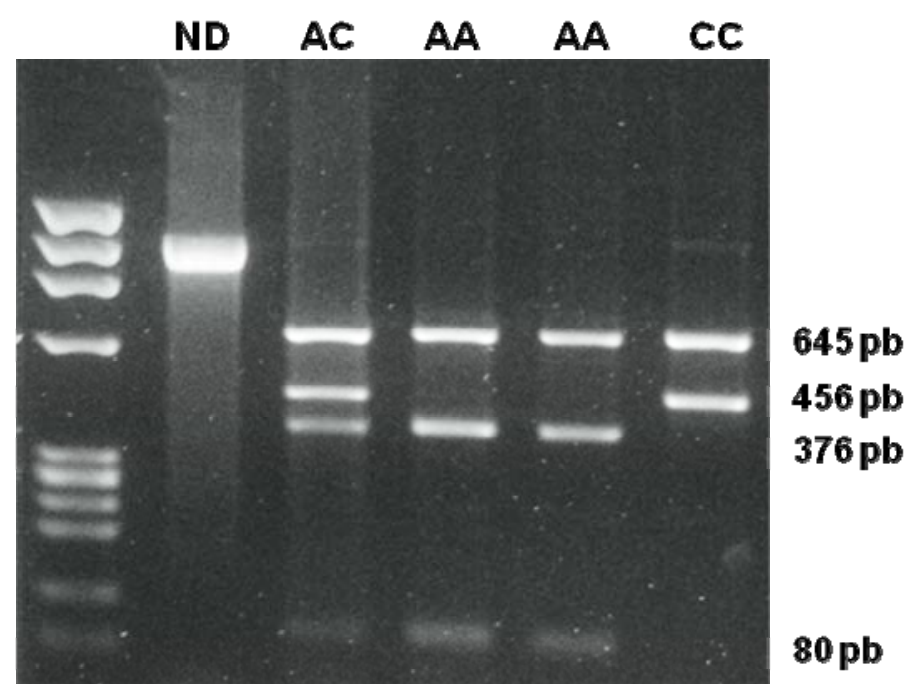

Figura 5: Foto de gel de agarose contendo produtos de digestão enzimática para genotipagem do SNP p.Ile544Leu do GHR: Fragmento de $1101 \mathrm{pb}$ da região de interesse (ND = fragmento não digerido) foi amplificado por PCR e submetido a digestão pela enzima HpyCH4V. Alelos $\mathrm{C}(=\mathrm{Leu})$ originam fragmentos de 645 e $456 \mathrm{pb}$, enquanto que os alelos $A(=\mathrm{lle})$ originam fragmentos de 645, 376 e $80 \mathrm{pb}$ 


\subsubsection{Microssatélite (CA)n na região promotora do IGF1}

O estudo da repetição $(\mathrm{CA}) \mathrm{n}$ da região promotora do gene do IGF-1 foi realizado conforme protocolo descrito por Vaessen e col (76): um fragmento da região flanqueadora do polimorfismo foi amplificado através de PCR, utilizando-se um par de primers específicos, sendo o primer reverso marcado com o fluorocromo FAM (sense: 5' ACCACTCTGGGAGAAGGGTA 3' e antisense: 5' GCTAGCCAGCTGGTGTTATT 3'). Todas as amplificações foram realizadas utilizando-se um termociclador automático GeneAmp $P C R$ Instrument System 9600 (Prkin-Elmer/Cetus, Norwalk,CT, USA) e acompanhadas de um controle negativo (todos os reagentes, exceto o DNA) para um volume final de $25 \mu \mathrm{L}$, contendo $50 \mathrm{ng}$ de DNA genômico, 15 pmols de cada primer, 240 uM de dNTP, 1,5 nM de $\mathrm{MgCl}_{2}, 2 \mathrm{U}$ de Taq polimerase (GoTaq promega $®$ ) e $5 \mu \mathrm{L}$ do tampão da enzima. A reação de PCR consistiu em uma denaturação inicial a $94^{\circ} \mathrm{C}$ por 10 minutos; 30 ciclos de denaturação a $94^{\circ} \mathrm{C}$ por 30 segundos, annealing a $55^{\circ} \mathrm{C}$ por 30 segundos e extensão a $72^{\circ} \mathrm{C}$ por 30 segundos; um último ciclo, 10 minutos a $72^{\circ} \mathrm{C}$ para extensão final. Em seguida, $2 \mu \mathrm{L}$ do produto de amplificação foram misturados com $24 \mu \mathrm{L}$ de formamida deionizada e $1 \mu \mathrm{L}$ do padrão de peso molecular Rox 2500 (Applied Biosystem) ou Rox 500 (Applied System), submetidos à denaturação a $94^{\circ} \mathrm{C}$ por 4 minutos e resfriados em gelo por 5 minutos. Estas amostras foram finalmente submetidas a eletroforese capilar em seqüenciador automático ABI PRISM 3100 Genetic Analyzer (Applied Biosystem) e os fragmentos analisados pelo software de 
análise de fragmentos GeneScan. Através do sequenciamento de amostras aleatórias, nos certificamos de que os fragmentos correspondentes ao alelo de 192 pb observado no Gene Scan correspondiam à sequências de 19 repetições CA, tal como descrito em estudos anteriores ${ }^{(68,75,76)}$.

\subsubsection{Polimorfismo -202 A/C da região promotora do IGFBP3}

O estudo do polimorfismo $-202 \mathrm{~A} / \mathrm{C}$ da região promotora do IGFBP3 foi realizado conforme o seguinte protocolo: o DNA genômico foi amplificado através de PCR, utilizando-se um par de primers específicos (sense: 5' GAGTTGGCCAGGAGTGACTG 3' e antisense: 5' GTGGAATCCAGGCAGGAAG 3'). Todas as amplificações foram acompanhadas de um controle negativo. Para um volume final de $25 \mu \mathrm{L}$, cada reação continha 100 ng de DNA genômico, 20 pmol de cada primer, 0,2 $\mathrm{mmol} / \mathrm{L}$ de cada deoxinucleotídeo trifosfato, $1,5 \mathrm{nM}$ de $\mathrm{MgCl}_{2}, 1 \mathrm{U}$ de Taq DNA polimerase (GoTaq®), 2,5 $\mu \mathrm{L}$ do tampão da enzima e $1 \mu \mathrm{L}$ de betaína. A reação de PCR consistia em uma desnaturação inicial a $95^{\circ} \mathrm{C}$ por 10 minutos; seguida de 36 ciclos de desnaturação a $95^{\circ} \mathrm{C}$ por 45 segundos, annealing a $57^{\circ} \mathrm{C}$ por 30 segundos e extensão a $72^{\circ} \mathrm{C}$ por 1 minuto; além de um último ciclo de 10 minutos a $72^{\circ} \mathrm{C}$ para extensão final. Essa reação originava fragmentos de 376 pb, que eram a seguir submetidos a digestão enzimática com 1 UI da enzima de restrição Fspl (NEB, Beverly, MA). Inicialmente todos os reagentes necessários para a digestão (enzima Fspl e tampão NEB4) eram combinados em uma solução que era distribuída igualmente para todas as amostras de produto de PCR a serem analisadas. 
A seguir, as amostras eram incubadas a $37^{\circ} \mathrm{C}$ overnight. Os fragmentos de restrição eram separados por eletroforese em gel de agarose a $2 \%$ contendo brometo de etídio, sempre acompanhado de uma amostra de produto de PCR não digerida, e posteriormente visualizados sob luz ultravioleta. Os produtos de PCR que apresentavam o nucleotídeo A na posição -202 formavam fragmentos com $376 \mathrm{bp}$, enquanto os que apresentavam o nucleotídeo C na mesma posição originavam fragmentos de 260 e 116 pb. A validade das análises por digestão enzimática foi verificada por seqüenciamento de uma amostra de cada genótipo usando BigDye FN Sequencing kit (PE Applied Biosystems, Foster City, CA). Para controle de qualidade, foram regenotipadas aproximadamente $10 \%$ de amostras randomicamente selecionadas. A concordância dos genótipos determinados pelas amostras controle de qualidade foi de $100 \%$.

\subsection{Análises Estatísticas}

A resposta ao tratamento com $\mathrm{rhGH}$ a curto prazo foi avaliada pela velocidade de crescimento (VC) no primeiro ano de tratamento; enquanto que a resposta a longo prazo foi avaliada pelo escore de DP (Z) da altura final com a correção pela altura dos pais. Como endpoints secundários, foram avaliados o ganho de $Z$ de altura no primeiro ano de tratamento e ao longo de todo o tratamento e o $\mathrm{Z}$ de altura final absoluto. 
No intuito de avaliar se as variações genéticas apresentavam significância prognóstica independente, realizamos prioritariamente análises de regressão linear múltipla ajustando para os demais fatores moduladores da capacidade de resposta ao tratamento com rhGH. Inicialmente, foram realizadas análises de regressão linear simples com o objetivo de identificar quais as variáveis clínicas que se correlacionavam a cada parâmetro de resposta de crescimento na nossa casuística. As variáveis testadas foram as que classicamente se correlacionam com a capacidade de resposta ao tratamento com rhGH, tais como: $Z$ da altura-alvo, $Z$ de altura inicial, idade óssea e cronológica iniciais, dose média de rhGH utilizada e duração do tratamento, entre outras. Apesar de ter sido relacionado à capacidade de resposta em muitos estudos, o pico de $\mathrm{GH}$ obtido em testes de estímulo foi excluído das análises devido ao fato de terem sido utilizadas três diferentes metodologias para a sua mensuração no presente estudo. A seguir, as variáveis que apresentavam $p<0,1$ nas análises de regressão linear simples foram selecionadas para as análises de regressão linear múltipla. Nessas análises, os genótipos foram representados sob a forma de coeficientes. Para os polimorfismos cujo modelo de herança genética já havia sido previamente estabelecido na literatura, mantivemos o modelo classicamente descrito. Para os polimorfismos cujo modelo não havia sido previamente descrito, testamos a influência sob as diferentes formas de herança possíveis: recessivo, codominante e dominante ${ }^{(95)}$.

Os pacientes foram ainda agrupados conforme o genótipo para comparações diretas com relação a parâmetros clínicos, auxológicos e 
laboratoriais. Variáveis qualitativas foram listadas como freqüências e percentagens, enquanto que variáveis quantitativas foram expressas como média \pm desvio-padrão (DP). Para comparações conforme modelos recessivos ou dominantes, em que dois dos três genótipos possíveis são agrupados, foram utilizados test-t ou Mann-Whitney Rank Sum Test, de acordo com a presença de distribuição paramétrica ou não, respectivamente. Para comparações conforme o modelo codominante, em que os três grupos genotípicos foram avaliados separadamente, foram utilizados One Way Analysis of Variance (ANOVA) ou Kruskal-Wallis ANOVA on Ranks, conforme apropriado. Os dados nominais foram avaliados pelo teste quiquadrado, ou teste exato de Fisher, conforme apropriado.

Foi considerado estatisticamente significante um $p<0,05$. Todas análises estatísticas foram realizadas com SigmaStat para Windows (versão 3.5, SPSS, Inc., San Rafael, CA). 
4 RESULTADOS 


\subsection{Caracterização da casuística}

Oitenta e quatro indivíduos portadores de DGH (56 meninos e 28 meninas) foram avaliados. No início do tratamento, estes apresentavam idade cronológica (IC) de 8,2 \pm 4,2 anos, com importante atraso de idade óssea (diferença média de 4,1 $\pm 2,6$ anos em relação à IC) e baixa estatura acentuada ( $Z$ de altura inicial $=-4,2 \pm 1,4)$. Todos apresentavam pronunciado déficit de $\mathrm{GH}$, como demonstrado pelo pico de $\mathrm{GH}$ após testes de estímulo extremamente baixo (média de 0,9 $\pm 0,8 \mu \mathrm{g} / \mathrm{L}$, variando entre $<0,1$ e 3,3 $\mu \mathrm{g} / \mathrm{L})($ Tabela 2). Não houve diferença com relação ao pico máximo de $\mathrm{GH}$ entre os pacientes diagnosticados pelos diferentes ensaios.

Noventa e dois por cento dos pacientes apresentavam etiologia genética definida (12 indivíduos) ou anormalidade anatômica à RNM da região hipotálamo-hipofisária (hipoplasia de adenohipófise em 65, neurohipófise ectópica em 49 a transsecção de haste em 22). Trinta e quatro pacientes apresentavam DGHI e 50 apresentavam DGHC. Entre os indivíduos com deficiência combinada, $92 \%$ apresentavam hipotireoidismo, $60 \%$ hipogonadismo, $50 \%$ hipocortisolismo e $14 \%$ diabetes insípidus. Pacientes com deficiência de $\mathrm{GH}$ isolada ou combinada apresentavam respostas de crescimento semelhantes durante o tratamento e por isso foram analisados em conjunto. Todos os indivíduos estudados permaneceram pré-púberes do início ao final do primeiro ano de tratamento com rhGH. 
Dos 84 indivíduos incluídos no estudo, 37 atingiram estatura final após pelo menos 3 anos (em média 8,6 anos) de tratamento com rhGH, sendo portanto avaliados quanto aos parâmetros de resposta a longo prazo. Quando comparados ao conjunto de toda casuística, esse subgrupo de indivíduos demonstrou ter iniciado tratamento com idade cronológica em média dois anos maior e ter utilizado doses médias de rhGH discretamente superiores (Tabela 2).

Tabela 2: Características clínicas e auxológicas dos pacientes selecionados

\begin{tabular}{lccc}
\hline & $\begin{array}{c}\text { Casuistica } \\
\text { Completa }\end{array}$ & $\begin{array}{c}\text { Subgrupo } \\
\text { altura final }\end{array}$ & $\boldsymbol{p}$ \\
\hline$n$ & 84 & 37 & - \\
Sexo (masculino: feminino) & $56: 28$ & $26: 11$ & $\mathrm{~ns}$ \\
GDH combinada: isolada & $50: 34$ & $23: 14$ & $\mathrm{~ns}$ \\
Z da altura-alvo & $-0,9 \pm 0,8$ & $-1,0 \pm 0,8$ & $\mathrm{~ns}$ \\
Z de altura inicial & $-4,2 \pm 1,4$ & $-4,6 \pm 1,6$ & $\mathrm{~ns}$ \\
Idade cronológica inicial (anos) & $8,2 \pm 4,2$ & $10,4 \pm 3,7$ & 0,008 \\
Atraso de idade óssea inicial (anos) & $4,1 \pm 2,6$ & $5,2 \pm 2,9$ & 0,028 \\
Pico de GH máximo( $\mu$ g/L) & $0,9 \pm 0,8$ & $1,0 \pm 0,9$ & $\mathrm{~ns}$ \\
Z de IGF-1 inicial & $-2,4 \pm 1$, & $-2,5 \pm 1,2$ & $\mathrm{~ns}$ \\
Z de IGFBP-3 inicial & $-2,6 \pm 1,1$ & $-2,6 \pm 1,3$ & $\mathrm{~ns}$ \\
Dose de GH média ( $\mu \mathrm{gg} / \mathrm{kg} / \mathrm{d})$ & $32,6 \pm 5,6$ & $35,7 \pm 7,9$ & $<0,001$ \\
VC no 10 ano de tratamento (cm) & $11,6 \pm 2,5$ & $11,5 \pm 2,4$ & $\mathrm{~ns}$ \\
Duração do tratamento (anos) & - & $8,6 \pm 3,0$ & - \\
Z de altura final & - & $-0,9 \pm 1,0$ & - \\
Z de altura final ajustada pelo & - & $0,1 \pm 1,2$ & - \\
Z de altura-alvo & - & $3,6 \pm 1,6$ & - \\
Ganho em Z de altura do início & & & \\
ao final do tratamento & & & \\
\hline
\end{tabular}




\subsection{Distribuição genotípica}

A Tabela 3 contém as freqüências genotípicas e alélicas dos polimorfismos estudados na nossa casuística. Todos os polimorfismos apresentaram distribuição genotípica compatível com o equilíbrio de Hardy Weinberg, permitindo sua utilização para posterior análise estatística.

De forma interessante, observamos que todos os indivíduos que apresentavam o alelo C (correspondente ao aminoácido Leu) no códon 544 do exon 10 do GHR apresentavam a isoforma full-lenght do receptor (GHRfl), sugerindo portanto que esses dois polimorfismos se encontram em desequilíbrio de ligação.

Tabela 3: Lista dos genes e respectivos polimorfismos selecionados: distribuição genotípica na presente casuística

\begin{tabular}{|c|c|c|c|}
\hline Gene & Polimorfismo & Freqüência genotípica & Frequência alélica \\
\hline \multicolumn{4}{|l|}{ GHR } \\
\hline & GHR fI/d3 & $\begin{array}{c}\text { fl/fl } 43 \% \\
\text { fl/d3 } 44 \% \\
\text { d3/d3 } 13 \%\end{array}$ & $\begin{array}{l}\text { fl } 65 \% \\
\text { d3 35\% }\end{array}$ \\
\hline & $\begin{array}{l}\text { p.Ile544 Leu } \\
\text { (c.544 A / C) }\end{array}$ & $\begin{array}{l}\text { A/A } 39 \% \\
\text { A/C } 44 \% \\
\text { C/C } 17 \%\end{array}$ & $\begin{array}{l}\text { A } 61 \% \\
\text { C } 39 \%\end{array}$ \\
\hline \multicolumn{4}{|l|}{ IGF1 } \\
\hline & $\begin{array}{c}\text { Repetição } \\
\text { (CA)n }\end{array}$ & $\begin{array}{c}\text { 19CA/19CA 28\%; } \\
\text { não 19CA/ 19CA } 55 \% ; \\
\text { não 19CA / não 19CA } 17 \%\end{array}$ & $\begin{array}{l}\text { 19CA } 54 \% \\
18 C A 14 \% \\
20 \text { CA } 12 \% \\
21 C A 11 \% \\
\text { Outros } 9 \%\end{array}$ \\
\hline \multicolumn{4}{|c|}{ IGFBP3 } \\
\hline & $-202 \mathrm{~A} / \mathrm{C}$ & $\begin{array}{l}\text { A/A } 20 \% \\
\text { A/C } 56 \% \\
\text { C/C } 24 \%\end{array}$ & $\begin{array}{l}\text { A } 48 \% \\
\text { C } 52 \%\end{array}$ \\
\hline
\end{tabular}




\subsection{Análises de associações com a capacidade de resposta ao tratamento com rhGH}

\subsubsection{Variáveis Clínicas}

Dentre os parâmetros não genéticos que estiveram correlacionados à capacidade de resposta ao tratamento com $\mathrm{rhGH}$ em trabalhos prévios ${ }^{(9)}$, os que demonstraram influência sobre a resposta ao tratamento com rhGH na presente casuística foram:

- Para a velocidade de crescimento no primeiro ano de tratamento com rhGH (VC $1^{\circ}$ ano)

- $Z$ de altura inicial $(p<0,001)$

- Idade óssea (IO) inicial $(p<0,001)$

- Para $\circ \mathrm{Z}$ de altura final ajustado para $\circ \mathrm{Z}$ da altura familiar (target height-TH) (Z AF - Z TH)

- $Z$ de altura no início da puberdade $(p=0,06)$

- $\mathrm{LN}$ da dose média de $\operatorname{rhGH}(p=0,001)$

- Duração do tratamento $(p=0,08)$

Sendo assim, todas as análises de regressão linear múltipla envolvendo os respectivos genótipos foram ajustadas para os parâmetros clínicos acima indicados. 


\subsubsection{Variáveis Genéticas}

\subsubsection{Presença ou ausência do exon3 do GHR}

A influência do genótipo GHR-exon3 sobre a resposta ao tratamento com rhGH na presente casuística está resumidamente demonstrada na Tabela 4. Não houve influência significativa desse genótipo sobre a resposta ao tratamento com rhGH a curto prazo, embora tais análises tenham sido limitadas por um baixo poder estatístico. Com relação à resposta a longo prazo, foi observada uma influência significante e independente desse polimorfismo sobre a altura final ajustada para a altura-alvo, da mesma forma que demonstrado em estudos prévios.

Embora similares com relação aos demais parâmetros clínicos, indivíduos portadores de pelo menos um alelo GHRd3 apresentaram estatura final ajustada pela altura-alvo em média 0,99 superior à de indivíduos homozigotos para o alelo GHRfl (intervalo de confiança de $95 \%$ para diferença entre as médias $=0,17$ a 1,$81 ; p=0,03$ ) Isoladamente, esse polimorfismo responde por $13 \%$ da variabilidade do $Z$ de altura final ajustado pela altura-alvo $(p=0,02)$. Uma análise conjunta do genótipo quanto a esse locus $(p=0,02)$ associado ao LN da dose média de rhGH utilizada $(p=0,001)$ foi capaz de explicar $40 \%$ da variabilidade de respostas observada. 
Tabela 4: Influência do genótipo GHR-exon3 sobre a resposta ao tratamento com rhGH

\begin{tabular}{|c|c|c|c|}
\hline \multicolumn{4}{|c|}{ Comparações diretas entre os grupos genotípicos** } \\
\hline Parâmetro de resposta & GHRfI/fI & GHRd3/* & $p$ \\
\hline $\mathrm{n}$ & 36 & 48 & \\
\hline Velocidade de crescimento no $1^{\circ}$ ano & $11,3 \pm 2,3$ & $11,7 \pm 2,6$ & ns \\
\hline Delta $Z$ de altura no $1^{\circ}$ ano & $1,2 \pm 0,6$ & $1,3 \pm 0,7$ & ns \\
\hline$Z$ de Altura Final & $-1,2 \pm 0,9$ & $-0,7 \pm 1,0$ & ns \\
\hline Z de Altura Final - Z da Altura-Alvo & $-0,6 \pm 1,2$ & $0,4 \pm 1,1$ & 0,02 \\
\hline$Z$ de Altura Final - Z de Altura Inicial & $3,2 \pm 1,4$ & $3,9 \pm 1,7$ & ns \\
\hline \multicolumn{4}{|c|}{ Regressões lineares } \\
\hline$Z$ de Altura Final - $Z$ da altura-alvo & $p$ & $\mathbf{R}^{2}$ & \\
\hline Regressão Linear Simples & 0,02 & 0,13 & \\
\hline Regressão Linear Múltipla & 0,02 & 0,40 & \\
\hline
\end{tabular}

\subsubsection{Polimorfismo p.Leu 544 Ile do GHR}

Esse polimorfismo não demonstrou influência significativa sobre nenhum dos parâmetros analisados, tanto pela comparação direta entre os grupos genotípicos, quanto por análises de regressão linear simples e múltiplas nos modelos codominante, recessivo e dominante (Tabela 5).

Tabela 5: Influência do polimorfismo p.Leu 544 lle do GHR sobre a resposta ao tratamento com rhGH

\begin{tabular}{lcccc}
\hline \multicolumn{5}{c}{ Comparações diretas entre os grupos genotípicos } \\
\hline Parâmetros de resposta & Leu/Leu & Leu/lle & Ile/lle & $\boldsymbol{p}$ \\
\hline $\mathrm{n}$ & 14 & 37 & 33 & \\
VC $1^{\circ}$ ano & $11,7 \pm 1,9$ & $11,6 \pm 2,6$ & $11,6 \pm 2,4$ & $\mathrm{~ns}$ \\
Delta Z de altura $1^{\circ}$ ano & $1,4 \pm 0,6$ & $1,3 \pm 0,6$ & $1,1 \pm 0,6$ & $\mathrm{~ns}$ \\
Z de Altura Final & $-0,4 \pm 0,8$ & $0,2 \pm 1,1$ & $-0,02 \pm 1,5$ & $\mathrm{~ns}$ \\
Z Altura Final-Z Altura-Alvo & $-1,0 \pm 0,6$ & $-1,1 \pm 0,9$ & $-0,7 \pm 1,2$ & $\mathrm{~ns}$ \\
Z Altura Final-Z Altura Inicial & $3,8 \pm 2,5$ & $3,5 \pm 1,5$ & $3,7 \pm 1,7$ & $\mathrm{~ns}$ \\
\hline
\end{tabular}




\subsubsection{Microssatélite (CA)n do IGF1}

A influência do genótipo (CA)n IGF1 sobre a resposta ao tratamento com rhGH está resumidamente demonstrada nas Tabelas 6 e 7. Os grupos genotípicos eram similares quanto às características basais, tais como sexo, idade cronológica, idade óssea e $Z$ de altura inicial.

Não foi observada influência significativa desse genótipo sobre as concentrações séricas de IGF-1, tanto antes quanto durante o tratamento com rhGH. Por outro lado, as respostas de crescimento observadas foram consistentemente inferiores nos indivíduos homozigotos para o alelo de 19 repetições CA (grupo 19/19 CA). Análises de regressão linear múltipla demonstraram influência significante e independente desse polimorfismo sobre a velocidade de crescimento no primeiro ano de tratamento quando ajustada para as demais variáveis preditivas desse parâmetro. O modelo resultante da análise conjunta do $Z$ de altura inicial ( $p=0,02)$, idade óssea inicial $(p=0,001)$ e o genótipo (CA)n IGF1 $(p=0,03)$ explicava $20 \%$ da variabilidade da velocidade de crescimento no primeiro ano (Tabela 6). 
Tabela 6: Influência do genótipo (CA)n IGF1 sobre a resposta ao tratamento com rhGH a curto prazo

\begin{tabular}{|c|c|c|c|}
\hline \multicolumn{4}{|c|}{ Comparações diretas entre os grupos genotípicos } \\
\hline & 19/19CA & não19CA / * & $p$ \\
\hline $\mathrm{n}$ & 24 & 60 & \\
\hline Sexo masculino : feminino & $18: 6$ & $32: 28$ & ns \\
\hline DGH combinada: isolada & $18: 6$ & $38: 22$ & ns \\
\hline Idade cronológica inicial (anos) & $7,5 \pm 3,7$ & $8,5 \pm 4,4$ & ns \\
\hline Idade óssea inicial & $3,4 \pm 2,1$ & $3,9 \pm 2,7$ & ns \\
\hline$Z$ de altura inicial & $-4,0 \pm 1,2$ & $-4,3 \pm 1,5$ & ns \\
\hline Dose de rhGH média ( $\mu \mathrm{g} / \mathrm{kg} / \mathrm{dia})$ & $33 \pm 5$ & $32 \pm 6$ & ns \\
\hline Velocidade de crescimento no $1^{\circ}$ ano & $10,7 \pm 2,1$ & $11,8 \pm 2,6$ & 0,05 \\
\hline Delta $Z$ de altura no $1^{\circ}$ ano & $1,1 \pm 0,5$ & $1,3 \pm 0,7$ & ns \\
\hline Z de IGF-1 pré-tratamento & $-2,1 \pm 0,8$ & $-2,5 \pm 1,1$ & ns \\
\hline$Z$ de IGF-1 durante o tratamento & $-0,6 \pm 1,4$ & $-0,3 \pm 1,5$ & ns \\
\hline \multicolumn{4}{|c|}{ Regressões lineares } \\
\hline Velocidade de crescimento $1^{\circ}$ ano & $p$ & $\mathbf{R}^{2}$ & \\
\hline Regressão Linear Simples & 0,05 & 0,08 & \\
\hline Regressão Linear Múltipla & 0,03 & 0,20 & \\
\hline
\end{tabular}

No grupo avaliado com relação à resposta à longo prazo (Tabela 7), o genótipo (CA)n IGF1 demonstrou influenciar tanto $\mathrm{O} Z$ de altura final ajustado para a altura-alvo como o ganho total em $Z$ de altura ao longo do tratamento. Indivíduos com pelo menos 1 alelo alternativo ao de 19 repetições CA (grupo não $19 \mathrm{CA}^{*}$ ), embora tenham sido tratados em média por menos tempo, apresentaram $Z$ de altura final em média 1SDS superior ao de indivíduos com ambos alelos 19CA (IC 95\% = 0,15 a 1,8), o que se 
demonstrou independente de outros parâmetros clínicos através das análises de regressão linear múltipla. Isoladamente, esse polimorfismo responde por $15 \%$ da variabilidade do $Z$ de altura final ajustado pelo alvo $(p=0,029)$. Uma análise conjunta do genótipo $(p=0,002)$ associado ao $Z$ de altura no início da puberdade $(p=0,04)$ e LN da dose média $(p<0,001)$ foi capaz de explicar $54 \%$ da variabilidade observada.

Tabela 7: Influência do genótipo (CA)n IGF1 sobre a resposta ao tratamento com rhGH a longo prazo

\begin{tabular}{|c|c|c|c|}
\hline \multicolumn{4}{|c|}{ Comparações diretas entre os grupos genotípicos } \\
\hline & 19/19CA & não19CA / * & $p$ \\
\hline $\mathrm{n}$ & 12 & 25 & \\
\hline Sexo masculino : feminino & $9: 3$ & $17: 8$ & ns \\
\hline DGH combinada: isolada & $7: 5$ & $16: 9$ & ns \\
\hline Idade cronológica inicial (anos) & $8,7 \pm 3,0$ & $11,8 \pm 3,7$ & ns \\
\hline$Z$ de altura inicial & $-4,1 \pm 1,1$ & $-4,8 \pm 1,8$ & ns \\
\hline$Z$ da altura-alvo & $-0,8 \pm 0,6$ & $-1,0 \pm 0,9$ & ns \\
\hline$Z$ de altura na puberdade & $-2,1 \pm 1,5$ & $-2,4 \pm 1,7$ & ns \\
\hline Duração do tratamento (anos) & $10,2 \pm 3,2$ & $7,9 \pm 2,7$ & 0,02 \\
\hline Dose de rhGH média ( $\mu \mathrm{g} / \mathrm{kg} / \mathrm{dia})$ & $36 \pm 8$ & $36 \pm 8$ & ns \\
\hline$Z$ de Altura Final & $-1,2 \pm 0,9$ & $-0,8 \pm 1,1$ & ns \\
\hline$Z$ de Altura Final - $Z$ da Altura-Alvo & $-0,6 \pm 1,2$ & $0,4 \pm 1,1$ & 0,02 \\
\hline$Z$ de Altura Final - $Z$ de Altura Inicial & $2,8 \pm 1,2$ & $4,0 \pm 1,7$ & 0,04 \\
\hline \multicolumn{4}{|c|}{ Regressões lineares } \\
\hline$Z$ de Altura Final - $Z$ da Altura-Alvo & $p$ & $\mathbf{R}^{2}$ & \\
\hline Regressão Linear Simples & 0,029 & 0,15 & \\
\hline Regressão Linear Múltipla & 0,002 & 0,54 & \\
\hline
\end{tabular}




\subsubsection{Polimorfismo -202 A/C do IGFBP3}

A influência do genótipo -202 A/C IGFBP3 sobre a resposta ao tratamento com rhGH está resumidamente demonstrada nas Tabelas 7 e 8 . De forma coerente com estudos prévios envolvendo as concentrações séricas de IGFBP-3 em adultos sem DGH ${ }^{(84)}$, os indivíduos homozigotos para o alelo A apresentaram concentrações séricas dessa proteína e respostas de crescimento consistentemente superiores às de indivíduos apresentando pelo menos um alelo $\mathrm{C}\left(\right.$ grupo $\mathrm{C} /{ }^{*}$ ).

Antes da terapia de reposição com $\mathrm{rhGH}$, a diferença das concentrações de IGFBP-3 entre os grupos genotípicos não foi estatisticamente significante. Com o tratamento, o incremento médio foi nitidamente superior nos indivíduos homozigotos para o alelo $\mathrm{A}$, resultando em maiores concentrações séricas de IGFBP-3 durante o tratamento nesse grupo genotípico (Tabela 8; Figura 6). Em análises de regressão linear múltipla, essa correlação se demonstrou independente de outras variáveis clínicas, tais com Z de IMC e dose de rhGH utilizada. Esse polimorfismo (-202 A/C IGFBP3) foi capaz de explicar $25 \%$ da variabilidade das concentrações séricas de IGFBP-3 durante o tratamento $(p<0,001)$ e, juntamente com idade $(p<0,001)$ e sexo $(p=0,02)$, respondia por $56 \%$ da variabilidade observada. Não houve influência significativa desse polimorfismo sobre as concentrações séricas de IGF-1. 
Tabela 8: Influência do genótipo -202 A/C IGFBP3 sobre as concentrações séricas de IGFBP-3 antes e durante o tratamento com rhGH

\begin{tabular}{lccc}
\hline \multicolumn{4}{c}{ Comparações diretas entre os grupos genotípicos } \\
\hline Parâmetro de resposta & $\mathbf{A A}$ & $\boldsymbol{C}{ }^{*}$ & $\boldsymbol{p}$ \\
\hline Z de IGFBP-3 pré-tratamento & $-2,0 \pm 12$ & $-2,7 \pm 1,1$ & 0,1 \\
Z de IGFBP-3 durante tratamento & $0,6 \pm 1,8$ & $-1,1 \pm 1,2$ & $<\mathbf{0 , 0 0 1}$ \\
Delta Z de IGFBP-3 & $2,8 \pm 1,4$ & $1,8 \pm 1,4$ & $\mathbf{0 , 0 2}$ \\
\hline \multicolumn{4}{c}{ Regressões lineares } \\
\hline Z de IGFBP-3 durante tratamento & $\boldsymbol{p}$ & $\mathbf{R}^{\mathbf{2}}$ & \\
\hline Regressão Linear Simples & $<0,001$ & 0,25 \\
Regressão Linear Múltipla & $<0,001$ & 0,56 \\
\hline
\end{tabular}

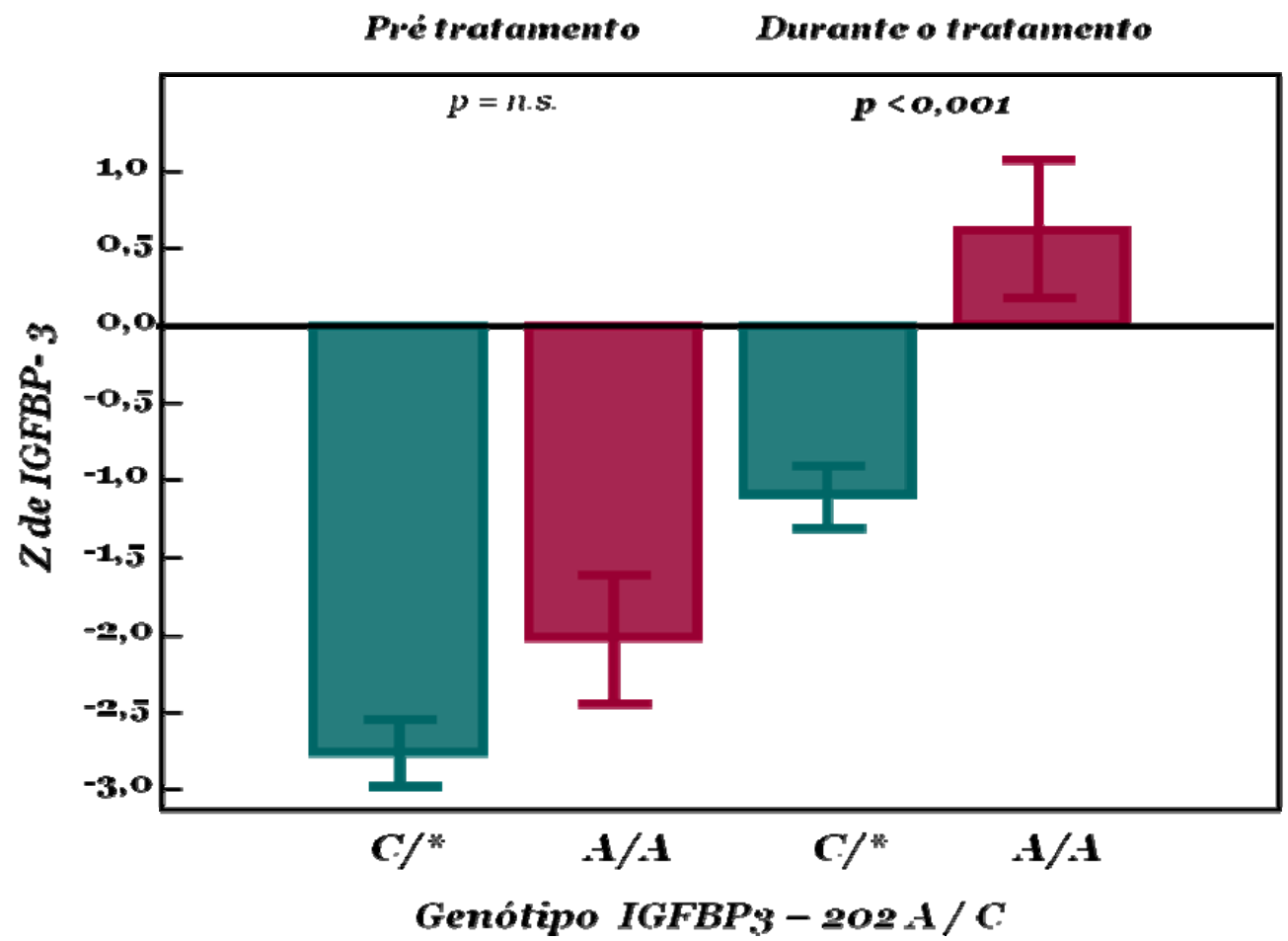

Figura 6: Representação gráfica da associação entre o genótipo -202 A/C IGFBP3 e o Z de IGFBP-3 sérica antes e durante o tratamento com rhGH 
No mesmo sentido, a velocidade de crescimento obtida no primeiro ano de tratamento com rhGH foi superior nos indivíduos homozigotos para o alelo A, declinando de forma progressiva na presença de uma ou duas cópias do alelo $C(p=0,003)$. Como grupo, pacientes com genótipo AA apresentaram VC em média 2,2 cm/ano superior à de indivíduos homozigotos ou heterozigotos para o alelo $\mathrm{C}$ (intervalo de confiança de $95 \%$ para diferença entre as médias = 0,9 a 3,4; $p=0,001$ ) (Tabela 9; Figura 7). Não houve diferença estatisticamente significante entre os grupos genotípicos com relação às características clínicas e laboratoriais ao início e durante o tratamento, tais como idade cronológica inicial e dose média utilizada (Tabela 9).

Tabela 9: Influência do genótipo -202 A/C IGFBP3 sobre a resposta ao tratamento com rhGH

\begin{tabular}{|c|c|c|c|}
\hline \multicolumn{4}{|c|}{ Comparações diretas entre os grupos genotípicos } \\
\hline Parâmetro de resposta & $A A$ & $C / *$ & $p$ \\
\hline $\mathrm{n}$ & 17 & 67 & \\
\hline Sexo masculino : feminino & $13: 4$ & $43: 24$ & ns \\
\hline DGH combinada: isolada & $12: 5$ & $38: 29$ & ns \\
\hline Idade cronológica inicial (anos) & $8,7 \pm 5,2$ & $8,1 \pm 3,9$ & ns \\
\hline Idade óssea & $3,5 \pm 2,9$ & $3,8 \pm 2,5$ & ns \\
\hline$Z$ de altura inicial & $-4,2 \pm 1,7$ & $-4,2 \pm 1,5$ & ns \\
\hline Dose de rhGH média ( $\mu \mathrm{g} / \mathrm{kg} / \mathrm{dia})$ & $32 \pm 2$ & $32 \pm 3$ & ns \\
\hline Velocidade de crescimento $1^{\circ}$ ano & $13,3 \pm 2,5$ & $11,1 \pm 2,3$ & $<0,001$ \\
\hline Delta $Z$ de altura no $1^{\circ}$ ano & $1,3 \pm 0,6$ & $1,1 \pm 0,8$ & ns \\
\hline$Z$ de Altura Final & $0,5 \pm 0,6$ & $-0,1 \pm 1,3$ & ns \\
\hline$Z$ de Altura Final - $Z$ da Altura-Alvo & $-0,6 \pm 0,6$ & $-1,0 \pm 1,1$ & ns \\
\hline$Z$ de Altura Final -Z de Altura Inicial & $3,7 \pm 1,0$ & $3,6 \pm 1,8$ & ns \\
\hline \multicolumn{4}{|c|}{ Regressões lineares } \\
\hline Velocidade de crescimento $1^{\circ}$ ano & $p$ & $\mathbf{R}^{2}$ & \\
\hline Regressão Linear Simples & $<0,001$ & 0,12 & \\
\hline Regressão Linear Múltipla & $<0,001$ & 0,26 & \\
\hline
\end{tabular}




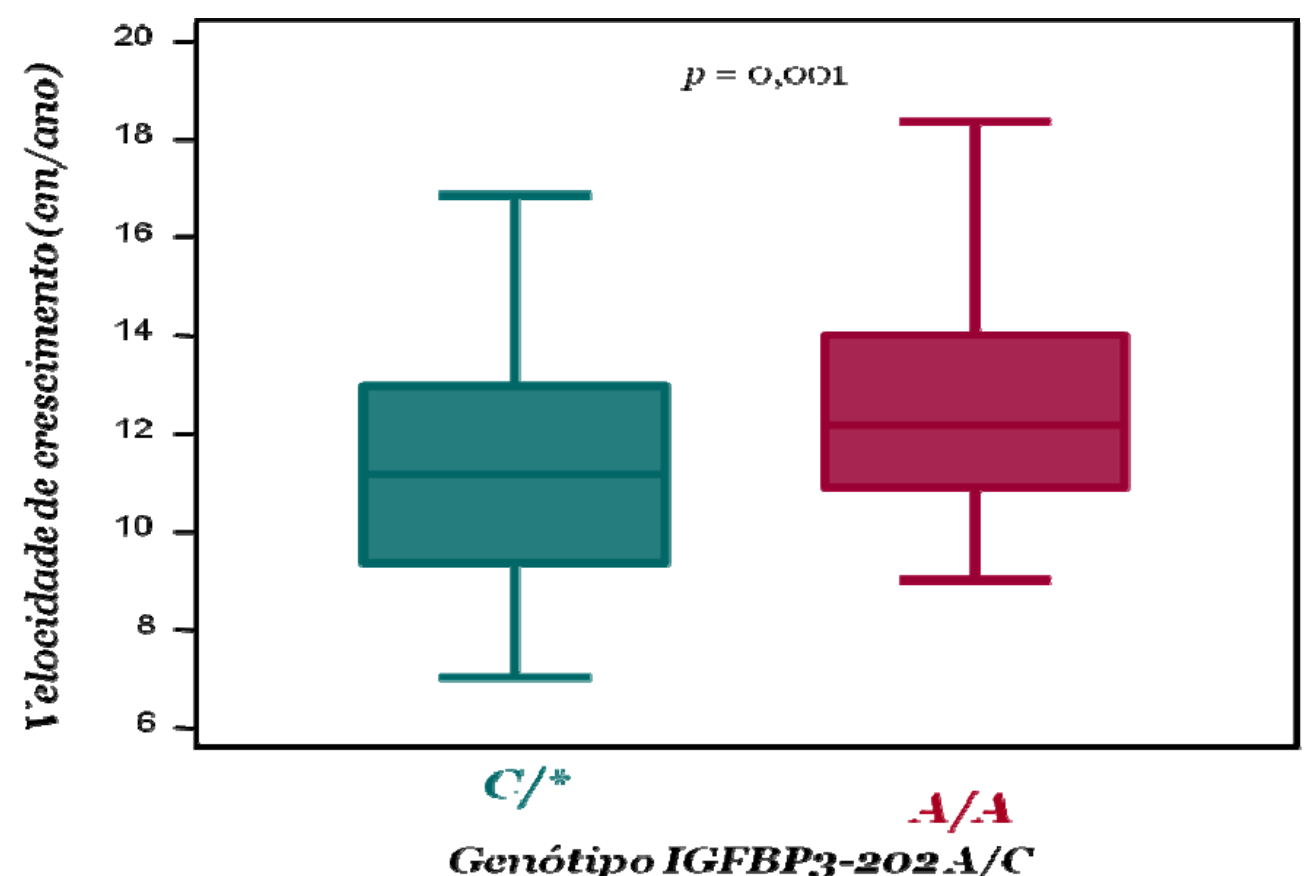

Figura 7: Representação gráfica da associação entre o genótipo -202 A/C IGFBP3 e a velocidade de crescimento no primeiro ano de tratamento com $\mathrm{rhGH}$

Através de análises de regressão linear múltipla, demonstramos que a influência do genótipo -202 A/C sobre a velocidade de crescimento obtida no primeiro ano de tratamento com rhGH foi independente de outras variáveis clínicas. Isoladamente, esse polimorfismo responde por $12 \%$ da variabilidade da VC no $1^{\circ}$ ano de tratamento com rhGH $(p<0,001)$. Uma análise conjunta do genótipo quanto a esse locus $(p<0,001)$ associado ao $Z$ de altura $(p=0,012)$ e idade óssea $(p=0,003)$ no início do tratamento foi capaz de explicar $26 \%$ da variabilidade de resposta observada.

Embora tenha havido uma tendência a um maior $Z$ de altura final ajustado para o $Z$ do alvo nos indivíduos homozigotos para o alelo $A$, essa diferença não foi estatisticamente significante. 


\subsubsection{Efeito interativo entre os polimorfismos estudados}

Considerando a possível presença de efeitos interativos que só pudessem ser evidenciados a partir da análise conjunta, realizamos análises de regressão linear múltipla envolvendo os polimorfimos agrupados dois a dois. Embora as análises tenham sido limitadas pelo pequeno número de indivíduos classificados em cada grupo, os resultados sugerem que a importância relativa de cada polimorfismo seja diferente conforme o parâmetro de resposta analisado.

Para a velocidade de crescimento no primeiro ano de tratamento com rhGH, tal qual demonstrado pelas análises independentes, as variáveis genéticas influentes foram o genótipo -202 A/C IGFBP3 e o genótipo (CA)n IGF1, os quais demonstraram apresentar uma influência independente e parcialmente aditiva. Indivíduos carreadores de pelo menos um alelo IGF1 não 19CA e homozigotos para o alelo IGFBP3 -202 A apresentaram velocidade de crescimento no primeiro ano em média $3,2 \mathrm{~cm}$ superior à de indivíduos homozigotos para o alelo IGF1 19CA e carreadores de pelo menos um alelo IGFBP3 -202 C (intervalo de confiança de 95\% para diferença entre as médias $=1,6$ a 4,9 cm/ano; $p<0,001)$ (Tabela 10, Figura 8). Análises de regressão linear múltipla demonstraram que isoladamente esses dois polimorfismos explicam $15 \%$ da variabilidade de respostas no primeiro ano de tratamento $(p<0,001)$, e quando associados ao $Z$ de altura $(p=0,02)$ e idade óssea $(p<0,001)$ iniciais respondem por $29 \%$ da variabilidade da velocidade de crescimento no primeiro ano. 
Tabela 10: Influência combinada dos genótipos -202 A/C IGFBP3 e (CA)n IGF1 sobre a velocidade de crescimento no primeiro ano de tratamento com rhGH

\begin{tabular}{|c|c|c|c|c|c|}
\hline \multicolumn{6}{|c|}{ Comparações diretas } \\
\hline \multirow{3}{*}{$\begin{array}{l}\text { Polimorfismo } \\
\text {-202A/C IGFBP3 } \\
\text { (CA)n IGF1 }\end{array}$} & \multicolumn{4}{|c|}{ Grupos genotípicos } & \multirow[t]{3}{*}{$p$} \\
\hline & $\mathrm{C} /{ }^{*}$ & $\mathrm{C} /{ }^{*}$ & $A / A$ & $\mathrm{~A} / \mathrm{A}$ & \\
\hline & 19/19CA & não19CA/* & 19/19CA & não19CA/* & \\
\hline$n$ & 20 & 47 & 4 & 13 & \\
\hline VC no $1^{\circ}$ ano & $10,5 \pm 2,1$ & $11,4 \pm 2,3$ & $11,6 \pm 2,1$ & $13,8 \pm 2,5$ & 0,002 \\
\hline$n$ & 20 & \multicolumn{2}{|c|}{51} & 13 & \\
\hline VC no $1^{\circ}$ ano & $10,5 \pm 2,1$ & \multicolumn{2}{|c|}{$11,4 \pm 2,3$} & $13,8 \pm 2,5$ & 0,001 \\
\hline \multicolumn{6}{|c|}{ Regressões lineares } \\
\hline \multicolumn{4}{|c|}{$p$} & \multicolumn{2}{|l|}{$\mathbf{R}^{2}$} \\
\hline \multicolumn{2}{|c|}{ Regressão Linear Simples } & \multicolumn{2}{|l|}{$<0,001$} & \multicolumn{2}{|l|}{0,15} \\
\hline \multicolumn{2}{|c|}{ Regressão Linear Múltipla } & \multicolumn{2}{|l|}{$<0,001$} & \multicolumn{2}{|l|}{0,29} \\
\hline
\end{tabular}

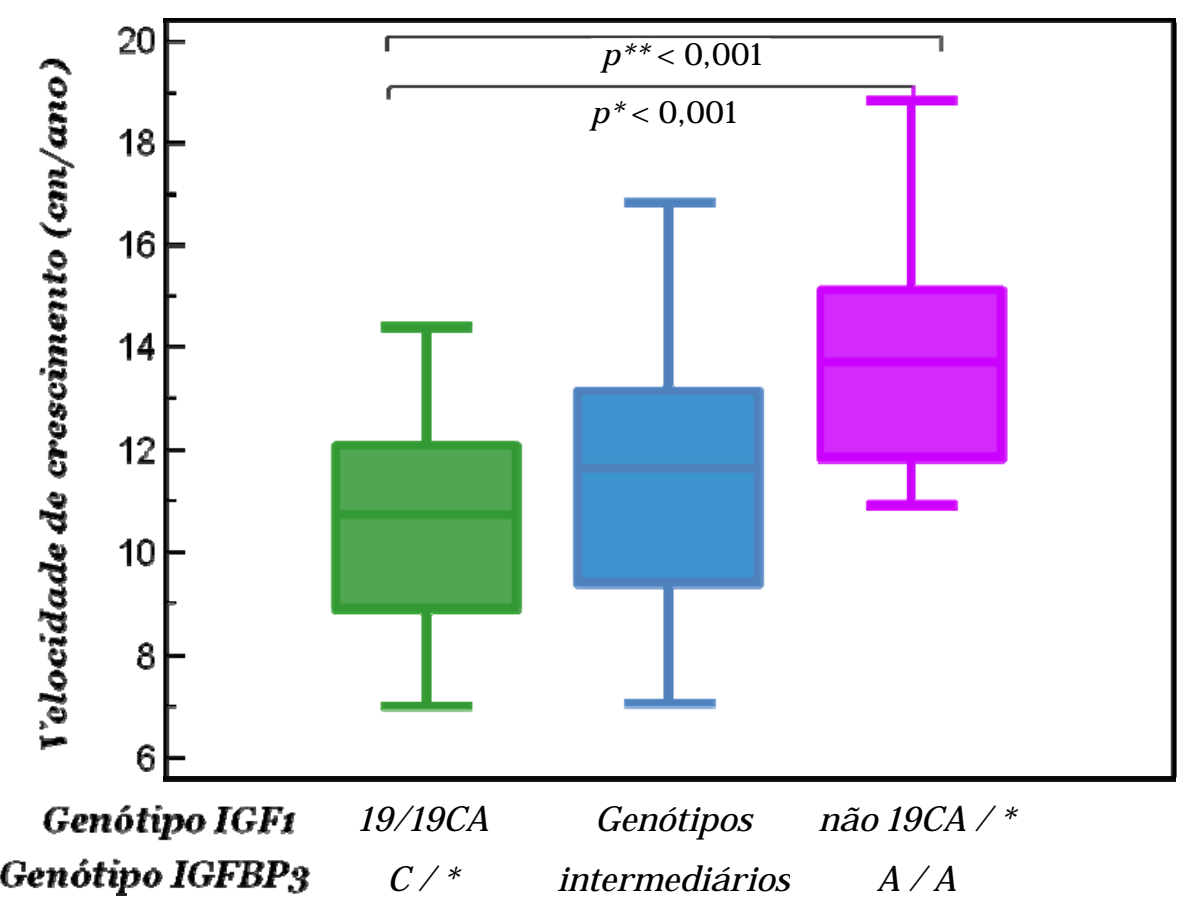

Figura 8: Representação gráfica da influência combinada dos genótipos -202 A/C IGFBP3 e (CA)n IGF1 sobre a velocidade de crescimento no primeiro ano de tratamento com rhGH $\left(\mathrm{p}^{*}=\right.$ ANOVA; $\mathrm{p}^{* *}=\mathrm{t}$-test); Genótipos intermediários: (IGF1 19/19CA e IGFBP3 AA) ou (IGF1 nao19CA/* e IGFBP3 C/*) 
Já com relação à altura final ajustada pelo alvo ( $\mathrm{AF}-\mathrm{ZTH})$, os dois fatores genéticos que demonstraram influência significativa foram o genótipo (CA)n IGF1 e o genótipo GHR-exon3. Indivíduos carreadores de pelo menos um alelo GHRd3 e um alelo IGF1 não 19CA apresentaram Z de altura final ajustada pelo $Z$ de altura-alvo em média 1,5 superior à de indivíduos homozigotos para os alelos GHRfl e IGF1 19CA (intervalo de confiança de $95 \%$ para diferença entre as médias $=0,4$ a 2,$6 ; p=0,01)$ (Tabela 11 , Figura 9). Isoladamente, esses dois polimorfismos explicam $23 \%$ da variabilidade deste parâmetro $(p=0,004)$ e, quando associados $(p<0,001)$ ao $Z$ de altura no início da puberdade $(p=0,035)$ e ao $L N$ da dose média de rhGH utilizada $(p<0,001)$, resultam em um modelo capaz de explicar $59 \%$ da variabilidade de resposta observada

Tabela 11: Influência combinada dos genótipos GHR-exon3 e (CA)n IGF1 sobre o $Z$ de altura final ajustado pelo $Z$ da altura-alvo após tratamento com rhGH

\begin{tabular}{|c|c|c|c|c|c|}
\hline \multicolumn{6}{|c|}{ Comparações diretas } \\
\hline \multicolumn{2}{|l|}{ Polimorfismo } & \multicolumn{3}{|c|}{ Grupos genotípicos } & \multirow[t]{3}{*}{$p$} \\
\hline GHR - exon3 & $\mathrm{fl} / \mathrm{fl}$ & $\mathrm{fl} / \mathrm{fl}$ & $d 3 /^{*}$ & $d 3 /^{*}$ & \\
\hline (CA)n IGF1 & 19/19CA & não19CA/* & 19/19CA & não19CA** & \\
\hline$N$ & 7 & 8 & 5 & 17 & \\
\hline Z AF - Z TH & $-0,9 \pm 1,3$ & $-0,09 \pm 0,9$ & $-0,05 \pm 0,9$ & $0,6 \pm 1,2$ & 0,048 \\
\hline$N$ & 7 & \multicolumn{2}{|c|}{13} & 17 & \\
\hline Z AF - Z TH & $-0,9 \pm 1,3$ & \multicolumn{2}{|c|}{$-0,07 \pm 0,8$} & $0,6 \pm 1,2$ & 0,002 \\
\hline \multicolumn{6}{|c|}{ Regressões lineares } \\
\hline & & \multicolumn{2}{|l|}{$p$} & \multicolumn{2}{|l|}{$\mathbf{R}^{2}$} \\
\hline \multicolumn{2}{|c|}{ Regressão Linear Simples } & \multicolumn{2}{|l|}{0,004} & \multicolumn{2}{|l|}{0,23} \\
\hline \multicolumn{2}{|c|}{ Regressão Linear Múltipla } & \multicolumn{2}{|c|}{$<0,001$} & \multicolumn{2}{|l|}{0,59} \\
\hline
\end{tabular}




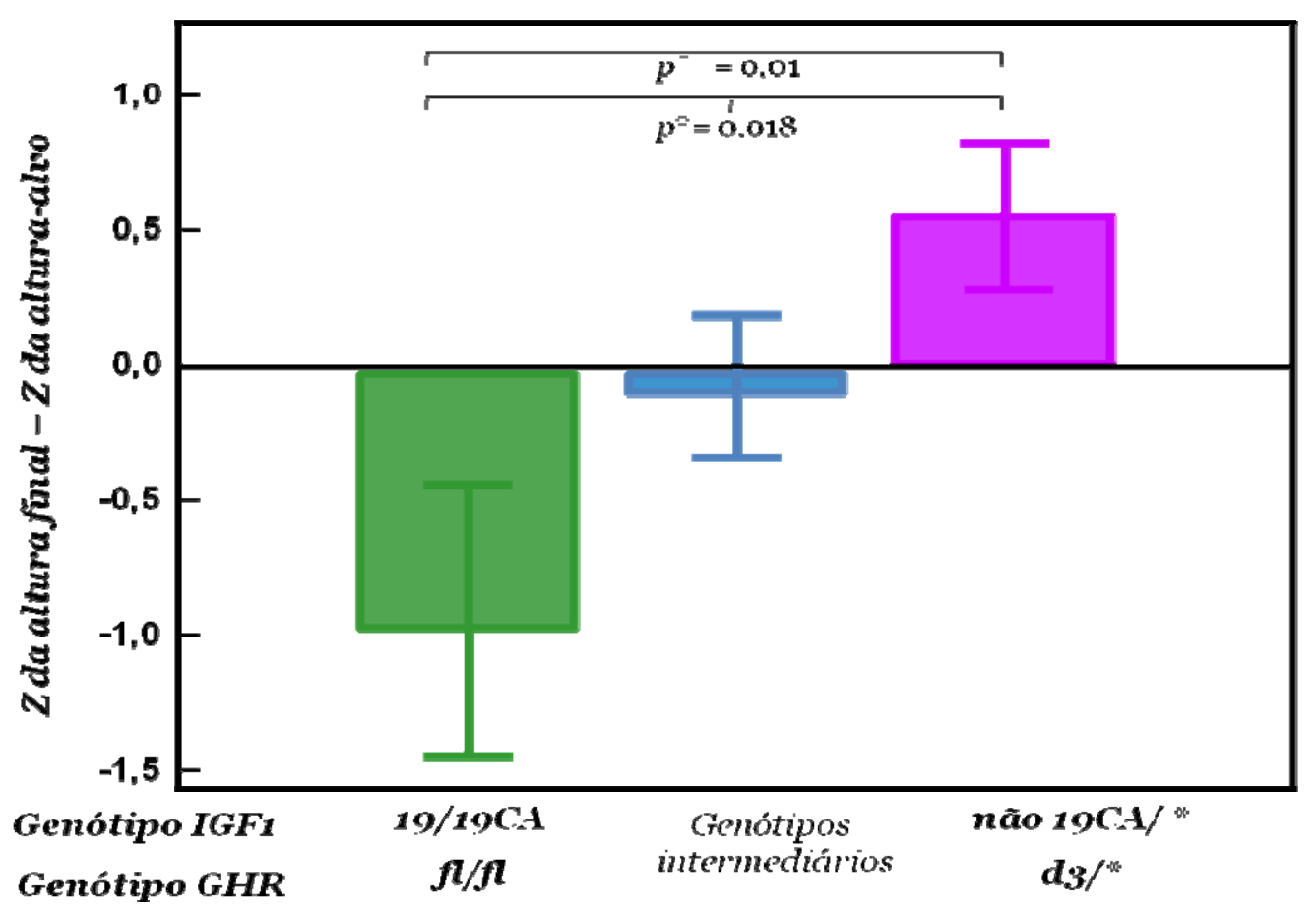

Figura 9: Representação gráfica da influência combinada dos genótipos GHR-exon3 e (CA)n IGF1 sobre o $Z$ de altura final ajustado pelo $Z$ da alturaalvo $\left(\mathrm{p}^{*}=\right.$ ANOVA; $\mathrm{p}^{* *}=\mathrm{t}$-test; Genótipos intermediários $=\left(\right.$ IGF1 não 19CA ${ }^{*}$ e GHRfl/fl) ou (IGF1 19/19CA e GHRd3/*) 


\section{DISCUSSÃO}


A farmacogenética tem sido vista como uma das principais aplicações clínicas dos substanciais avanços que ocorreram na ciência genômica nos últimos anos, constituindo importante movimento em direção à almejada medicina individualizada ${ }^{(16)}$. Apesar disso, estudos de farmacogenética do tratamento com rhGH só começaram a ser desenvolvidos nos últimos cinco anos, permanecendo até recentemente limitados ao estudo de polimorfismos do GHR.

No presente estudo, avaliamos a influência de quatro polimorfismos funcionais de três genes envolvidos nos mecanismos de ação do hormônio de crescimento sobre a resposta ao tratamento com rhGH em 84 crianças pré-púberes com DGH. Os resultados sugerem que três desses polimorfismos - GHRd3/fl, presente no GHR; -202 A/C, presente na região promotora do IGFBP3; e repetição (CA)n, da região promotora de IGF1 - possam atuar de forma independente e interativa na modulação da capacidade de reposta ao tratamento com rhGH.

\subsection{Presença ou ausência do exon 3 do GHR}

A presença ou ausência do exon3 do GHR foi a primeira variável genética envolvida com a capacidade de resposta ao tratamento com rhGH. Indivíduos carreadores de pelo menos um alelo GHRd3 apresentam 
evidências de maior sensibilidade às ações do $\mathrm{GH}$ que indivíduos homozigotos para o alelo GHRfl (Tabela 1). No entanto, a existência de estudos que não replicaram essa associação ainda desperta incredulidade quanto aos resultados destes primeiros trabalhos em farmacogenética do rhGH. Nesse sentido, é importante considerar que a replicabilidade variável é uma característica comum e extensamente discutida dos estudos de associação genética, e que hoje se sabe que pode estar relacionada a inúmeros fatores - incluindo não só a presença de resultados falsamente positivos (erro tipo 1) como também de resultados falsamente negativos (erro tipo 2) (Quadro 2). Dessa forma, conclusões definitivas só podem ser adotadas a partir de uma cuidadosa análise do desenho metodológico de cada estudo ${ }^{(21,97,98)}$ e do uso de instrumentos de compilação de evidências tais como revisões sistemáticas e metanálises.

Quadro 2: Fatores envolvidos na replicabilidade variavel de estudos de associação genética $(21,97,98)$

- Resultados Falso-positivos (Erro tipo 1)

- Resultados Falso-negativos (Erro tipo 2)

- Erros da genotipagem

- Erros de fenotipagem

- Modelos de herança utilizados em cada estudo

- Estratificação populacional

- Diferença real entre as populações estudadas. 
Nos estudos avaliando a influência do genótipo GHR-exon3 sobre a resposta ao tratamento com $\mathrm{rhGH}$ em crianças com $\mathrm{DGH}$ identifica-se a presença de uma série de possíveis fatores de confusão. Considerando-se que a DGH é uma condição clínica rara ${ }^{(99)}$, uma das principais limitações desses estudos é a dificuldade de obtenção de casuísticas suficientemente grandes para alcançar poder estatístico satisfatório (erro tipo 2) ${ }^{(40,64)}$. A primeira evidência a favor dessa observação é a de que nenhum estudo mostrou menor sensibilidade ao $\mathrm{GH}$ nos pacientes portadores do alelo GHRd3, o que seria esperado se os resultados obtidos fossem unicamente atribuídos ao acaso (erro tipo 1) ${ }^{(100)}$. A segunda limitação dos estudos de farmacacogenética do tratamento com rhGH em indivíduos com $\mathrm{DGH}$ é a heterogeneidade dos critérios utilizados para o diagnóstico da deficiência de $\mathrm{GH}$, que em muitos desses estudos ${ }^{(50,64,101)}$ foi fundamentado na presença de critérios laboratoriais pouco rígidos que sabidamente favorecem a inclusão de indivíduos com outras causas de baixa estatura (erro de fenotipagem $)^{(2,6,7,102-104)}$. Considerando-se que os pacientes com DGH apresentam respostas de crescimento nitidamente superiores às de indivíduos sem DGH ${ }^{(103,105)}$, a heterogeneidade etiológica constitui em importante fator de confusão na análise do potencial de resposta ao tratamento com rhGH; além de contribuir para a redução do poder de estatístico desses estudos.

No presente estudo, a ausência de influência do genótipo do GHRexon 3 sobre a velocidade de crescimento no primeiro ano pode ser atribuída ao limitado poder estatístico da amostra $(1-\beta=40 \%$ para 
detecção de diferença de $1 \mathrm{~cm} / a n o$ entre os grupos genotípicos) ${ }^{(106)}$. Com relação ao $Z$ de altura final ajustada para a altura-alvo, foi observada uma diferença estatisticamente significante, tanto nas análises por comparação direta quanto nas análises de regressão linear múltipla; o que corrobora os resultados publicados previamente em relação ao papel desse polimorfismo na farmacogenética do tratamento com rhGH em crianças com DGH.

\subsection{Polimorfismo p.lle544Leu do GHR}

Embora seja um importante polimorfismo candidato, dada a alta prevalência populacional e a possibilidade de importância funcional, os dados levantados pelo presente estudo não sugerem a presença de associação desse polimorfismo com a capacidade de resposta ao tratamento com rhGH.

Considerando-se que os estudos anteriores que demonstraram associações clínicas envolvendo esse polimorfismo não avaliaram o genótipo GHR-exon 3, pode-se hipotetizar que os resultados observados nesses estudos tenham sido, pelo menos em parte, atribuíveis ao seu estado de desequilíbrio de ligação com a presença ou ausência do exon 3 do GHR. 


\subsection{Microssatélite (CA)n do IGF1}

O segundo polimorfismo que demonstrou influenciar a capacidade de resposta ao tratamento com rhGH na presente casuística foi o microssatélite constituído por repetições CA localizado na região promotora do gene do IGF1.

Em 1998, Rosen e col. avaliaram a presença de correlação entre esse polimorfismo e as concentrações séricas de IGF-1 em diferentes coortes, tendo sido observado que o estado de homozigose para o alelo de 19 repetições $\mathrm{CA}$ se associava à presença de menores concentrações séricas de IGF-1 ajustadas para idade e sexo ${ }^{(68)}$. Outros estudos bem delineados demonstraram resultados semelhantes ${ }^{(71,79,80,87)}$, de forma a sugerir um papel funcional negativo desse genótipo (19/19CA) sobre a capacidade transcricional de IGF1. De forma interessante, em 2003, Rietveld e col. demonstraram que apenas os indivíduos homozigotos para o alelo 19CA apresentavam declínio significante de IGF-1 com a idade, levando os autores a sugerir que o mesmo poderia estar direta ou indiretamente influenciando de forma recessiva a regulação de IGF-1 que é mediada por $\mathrm{GH}^{(72)}$.

O presente estudo foi o primeiro a avaliar a influência desse polimorfismo sobre as concentrações séricas de IGF-1 e a resposta ao tratamento com rhGH de crianças com DGH. Nessa condição, os indivíduos homozigotos para a presença do alelo de 19 repetições CA demonstraram uma menor resposta de crescimento ao tratamento com rhGH, refletida tanto pela velocidade de crescimento no primeiro ano quanto pela altura final, de forma independente de outras variáveis clínicas preditivas. 
O mecanismo envolvido nas associações observadas com relação a esse polimorfismo ainda não foi esclarecido. Por estar localizado em uma região sabidamente regulatória do gene, é possível que variações no número de repetições CA interfiram com a capacidade de transcrição do IGF1, tal como descrito previamente para outros genes ${ }^{(107,108)}$. No entanto, dada a natureza associativa desses estudos, não é possível estabelecer uma relação causativa direta nem afastar a possibilidade de haver um desequilíbrio de ligação com uma segunda variante verdadeiramente funcional ${ }^{(74)}$.

A ausência de correlação deste microssatélite com as concentrações séricas de IGF-1 no presente estudo pode estar relacionada à conhecida variabilidade intra e interensaio das medidas de IGF-1 sérico ${ }^{(109,110)}$ e ao limitado poder estatítico da amostra. Além disso, é sabido que as ações promotoras de crescimento mediadas por IGF-1 são determinadas não apenas pelo IGF-1 circulante, mas também pelo gerado localmente nos tecidos (revisado na ref. (65), de forma que é possível que este locus desempenhe um papel na modulação da expressão do IGF1 em nível tecidual sem necessariamente modificar a sua concentração sérica.

\subsection{Polimorfismo -202 A/C do IGFBP3}

Desde a sua identificação em 2001, esta variante alélica tem sido implicada na determinação genética das concentrações séricas de IGFBP-3 em diferentes casuísticas constituídas de adultos sem DGH ${ }^{(84-86,89,90)}$. 
O presente estudo foi o primeiro a demonstrar a influência desse polimorfismo sobre as concentrações séricas de IGFBP-3 e a velocidade de crescimento após tratamento com rhGH em crianças com deficiência de $\mathrm{GH}$. Indivíduos homozigotos para o alelo A apresentaram concentrações séricas de IGFBP-3 e velocidades de crescimento no primeiro ano de tratamento com rhGH superiores às de indivíduos apresentando pelo menos um alelo $\mathrm{C}$. De forma interessante, a correlação do polimorfismo com as concentrações séricas de IGFBP-3 só se tornou estatisticamente significante após a terapia com rhGH, sugerindo que os mecanismos pelos quais o polimorfismo modula a expressão da proteína possam ser, pelo menos em parte, dependentes da ação de $\mathrm{GH}$.

Um estudo recente avaliou a influência desse polimorfismo sobre as concentrações séricas de IGFBP-3 e a resposta a curto prazo ao tratamento com rhGH em crianças nascidas PIG ${ }^{(56)}$. A análise comparativa com o presente estudo quanto à resposta ao tratamento com rhGH é prejudicada pela diferente condição clínica da casuística e pelo fato deste segundo estudo ter procedido a análises conjuntas do polimorfismo -202 A/C com um segundo polimorfismo da região promotora do IGFBP3 (-185 C/T). No entanto, este estudo também observou maior concentração sérica de IGFBP-3 nos pacientes portadores do alelo A no locus -202 e uma correlação direta do incremento de IGFBP-3 sérico com a capacidade de resposta ao tratamento com $\mathrm{rhGH}^{(56)}$.

Além do fato de prolongar a meia-vida plasmática do IGF-1, dessa forma modulando suas ações endócrinas ${ }^{(111,112)}$, a IGFBP-3 também é 
capaz de modular ações locais deste hormônio e apresentar ações sobre o crescimento que são independentes de IGF-1 (37,38,111). Embora todas IGFBPs tenham demonstrado inibir a ação de IGFs, efeitos estimulatórios foram também estabelecidos para as IGFBPs 1,3 e 5 (37,38,111). Há evidências tanto in vitro ${ }^{(101,113-119)}$ quanto in vivo ${ }^{(120,121)}$ que sustentam esses efeitos estimulatórios. O IGF-1 ligado a IGFBP-3 parece ser mais potente que IGF-1 livre em muitas situações ${ }^{(101,120-122)}$. In vitro, inúmeros mecanismos possíveis de potencialização da ação de IGF-1 foram sugeridos, tais como:

1) Interação com componentes da matriz extracelular, dessa forma concentrando IGF-1 próximo ao receptor;

2) Acúmulo de IGFBP na forma ligada à célula, com baixa afinidade por IGF, podendo aumentar a apresentação do IGF-1 ao seu receptor, devido à troca contínua de IGF-1 entre o receptor e a IGFBP, além do impedimento ao down regulation do receptor ${ }^{(116,118,123)}$;

3) Ligação a receptor próprio cuja via de sinalização interage coma via de IGF, amplificando suas ações ${ }^{(115)}$.

Assim, hipotetizamos que a maior atividade transcricional conferida pelo alelo $A^{(84)}$ tenha resultado em maiores concentrações séricas dessa proteína transportadora, o que por sua vez resultou em maior meia-vida plasmática e/ou amplificação dos efeitos locais do IGF-1, resultando em melhor resposta de crescimento após tratamento com rhGH. Vale ressaltar que o "efeito-reservatório" do aumento da meia-vida plasmática do IGF-1 
ocasionado pela IGFBP-3 circulante (através da formação de complexos ternários) pode ser particularmente importante em indivíduos com deficiência de GH. Nesses indivíduos, diferentemente de indivíduos com secreção de GH normal, há um comprometimento "basal" da formação de complexos ternários. Além disso, a geração de IGF-1 é dependente da ação de GH exógeno, administrado em dose fixa e única diária - o que sabidamente não mimetiza os pulsos fisiológicos de $\mathrm{GH}{ }^{(124-126)}$. Nessa situação, é provável que a importância de pequenas variações na capacidade geração de IGFBP3 em resposta a GH tornem-se ainda mais evidentes.

\subsection{Efeitos interativos}

Considerando-se que a resposta ao tratamento com rhGH é uma característica fenotípica de determinação genética complexa, a observação de associações genótipo-fenótipo, tais como as descritas no presente estudo, levam quase que instantaneamente ao questionamento sobre de que forma e com que intensidade os efeitos determinados por cada polimorfismo estariam interagindo para a determinação do resultado final. Um dos fatores que dificultam esse tipo de análise é que os efeitos determinados pela interação entre duas ou mais variantes gênicas na maioria das vezes não são claramente aditivos, dificultando sua detecção através de métodos clássicos como as regressões lineares. Por este motivo, a detecção e caracterização de epistasias, ou interações não aditivas entre genes, ainda constitui um 
importante desafio para os estudos de associação genética, geralmente requerendo um grande número de indivíduos para que se alcance adequado poder estatístico ${ }^{(127)}$. Embora modelos estatísticos de minimização dessas limitações tenham sido descritos ${ }^{(127,128)}$, até 0 momento esses métodos ainda não foram totalmente validados, podendo ser usados apenas como uma análise de dados exploratória, mas não para um teste de hipóteses formal ${ }^{(127)}$. Sendo assim, os resultados obtidos a partir das análises combinadas realizadas no presente estudo são ainda bastante limitados. Por outro lado, uma análise global da consistência dos resultados fornece indícios bastante interessantes da melhoria do poder preditivo à medida que variáveis genéticas adicionais são incluídas no modelo de predição; sugerindo que estudos futuros com casuísticas maiores sejam capazes de fornecer dados mais conclusivos sobre a natureza dessas interações.

\subsection{Considerações finais e perspectivas}

Acreditamos que o presente estudo contribuiu de forma substancial no sentido de dar os primeiros passos de um longo caminho rumo à compreensão do papel desempenhado por variantes genéticas comuns sobre a resposta ao tratamento com rhGH. Devido à dificuldade em obter um grande número de pacientes com DGH bem caracterizada que permita a condução de estudos de associação de maior poder estatístico, é provável que futuros estudos com casuísticas independentes e posteriormente 
meta-análises cuidadosamente conduzidas sejam necessários para a confirmação da importância desses e de outros polimorfismos implicados na farmacogenética do tratamento com rhGH.

Embora esta área da ciência médica pós-genômica apresente inúmeros desafios ainda difíceis de serem superados - tanto no campo da pesquisa em si quanto em termos de transferência para o campo da aplicabilidade clínica - os avanços obtidos até o momento sugerem que a farmacogenética indubitavelmente será aplicada na prática médica, e que propiciará uma melhora da nossa habilidade em individualizar o uso de importantes recursos terapêuticos desenvolvidos no curso da evolução farmacológica ${ }^{(129)}$.

No entanto, pesquisadores dessa área devem ser cuidadosos no sentido de não subestimar o tempo necessário para que se atinja esse complexo objetivo, uma vez que o efeito determinado por esses polimorfismos corresponde a apenas uma pequena parte do conjunto e este é apenas o início de um longo processo cujo objetivo final é o aprimoramento do cuidado ao paciente ${ }^{(129)}$. 
6 CONCLUSÕES 
- O polimorfismo -202 A/C do IGFBP3, a presença ou deleção do exon 3 do GHR e as repetições (CA)n do IGF1 estão associadas de forma independente e interativa à variabilidade de respostas ao tratamento com rhGH de indivíduos com deficiência de hormônio de crescimento (DGH).

- Indivíduos com DGH carreadores de pelo menos um alelo GHRd3 apresentam melhor altura final ajustada para a altura-alvo após tratamento com rhGH quando comparados aos homozigotos para o alelo GHRfl.

- O polimorfismo p.lle544Leu do GHR está em desequilíbrio de ligação com o polimorfismo GHR-exon3, mas não influencia de forma significativa a resposta ao tratamento com rhGH em indivíduos com DGH.

- Indivíduos com DGH homozigotos para o alelo de 19 repetições CA na região promotora do IGF1 apresentam velocidade de crescimento e altura final inferiores às de indivíduos apresentando pelo menos um alelo alternativo.

- Indivíduos pré-púberes com DGH homozigotos para o alelo A no locus -202 da região promotora do IGFBP3 apresentam velocidades de crescimento e concentrações séricas de IGFBP-3 após o primeiro ano de tratamento com rhGH superiores às de indivíduos carreadores de pelo menos um alelo C. 
- Os genótipos (CA)n IGF1 e -202 A/C IGFBP3 influenciam de forma interativa a velocidade de crescimento no primeiro ano de tratamento com rhGH em crianças pré-púberes com DGH.

- Os genótipos (CA)n IGF1 e GHR-exon3 influenciam de forma interativa a altura final ajustada para a altura-alvo após tratamento com rhGH em crianças com DGH. 
7 REFERÊNCIAS 
1. Raben MS 1958 Treatment of a pituitary dwarf with human growth hormone. J Clin Endocrinol Metab 18:901-903

2. Guyda HJ 1999 Four decades of growth hormone therapy for short children: what have we achieved? J Clin Endocrinol Metab 84:43074316

3. Lee KW, Cohen P 2001 Individualizing growth hormone dosing in children. Horm Res 56 Suppl 1:29-34

4. Rosenfeld RG 2006 Editorial: the pharmacogenomics of human growth. J Clin Endocrinol Metab 91:795-796

5. GH Research Society 2000 Consensus guidelines for the diagnosis and treatment of growth hormone $(\mathrm{GH})$ deficiency in childhood and adolescence: summary statement of the GH Research Society. J Clin Endocrinol Metab 85:3990-3993

6. Ranke MB, Schweizer R, Wollmann HA, Schwarze P 1999 Dosing of growth hormone in growth hormone deficiency. Horm Res 51 Suppl 3:70-74

7. Carel JC, Ecosse E, Nicolino M, Tauber M, Leger J, Cabrol S, BastieSigeac I, Chaussain JL, Coste J 2002 Adult height after long term treatment with recombinant growth hormone for idiopathic isolated growth hormone deficiency: observational follow up study of the French population based registry. Bmj 325:70

8. Ranke MB, Guilbaud O, Lindberg A, Cole T 1993 Prediction of the growth response in children with various growth disorders treated with growth hormone: analyses of data from the Kabi Pharmacia International Growth Study. International Board of the Kabi Pharmacia International Growth Study. Acta Paediatr Suppl 82 Suppl 391:82-88; discussion 89

9. Costalonga EF, Jorge AA, Mendonca BB, Arnhold IJ 2008 [Mathematical models for predicting growth responses to growth hormone replacement therapy]. Arq Bras Endocrinol Metabol 52:839849

10. Ranke MB 1999 Prediction of response to $\mathrm{GH}$ : does it help to individualize therapy? Current Opinion in Endocrinology and Diabetes 6:93-99 
11. Spear BB, Heath-Chiozzi M, Huff J 2001 Clinical application of pharmacogenetics. Trends Mol Med 7:201-204

12. Geffner ME, Dunger DB 2007 Future directions: growth prediction models. Horm Res 68 Suppl 5:51-56

13. Kristrom B, Wikland KA 2002 Growth prediction models, concept and use. Horm Res 57 Suppl 2:66-70

14. Wikland KA, Kristrom B, Rosberg S, Svensson B, Nierop AF 2000 Validated multivariate models predicting the growth response to $\mathrm{GH}$ treatment in individual short children with a broad range in $\mathrm{GH}$ secretion capacities. Pediatr Res 48:475-484

15. Weinshilboum R 2003 Inheritance and drug response. N Engl J Med 348:529-537

16. Weinshilboum RM, Wang L 2006 Pharmacogenetics and pharmacogenomics: development, science, and translation. Annu Rev Genomics Hum Genet 7:223-245

17. Alving AS, Carson PE, Flanagan CL, Ickes CE 1956 Enzymatic deficiency in primaquine-sensitive erythrocytes. Science 124:484-485

18. Nebert DW, Vesell ES 2004 Advances in pharmacogenomics and individualized drug therapy: exciting challenges that lie ahead. Eur $\mathrm{J}$ Pharmacol 500:267-280

19. Need AC, Motulsky AG, Goldstein DB 2005 Priorities and standards in pharmacogenetic research. Nat Genet 37:671-681

20. Manolio TA, Brooks LD, Collins FS 2008 A HapMap harvest of insights into the genetics of common disease. J Clin Invest 118:1590-1605

21. Shen H, Liu Y, Liu P, Recker RR, Deng HW 2005 Nonreplication in genetic studies of complex diseases--lessons learned from studies of osteoporosis and tentative remedies. J Bone Miner Res 20:365-376

22. Hockett RD, Kirkwood SC, Mitlak BH, Dere WH 2002 Pharmacogenomics in endocrinology. J Clin Endocrinol Metab 87:24952499

23. 2005 A haplotype map of the human genome. Nature 437:1299-1320

24. 2003 The International HapMap Project. Nature 426:789-796

25. Goldstein DB, Ahmadi KR, Weale ME, Wood NW 2003 Genome scans and candidate gene approaches in the study of common diseases and variable drug responses. Trends Genet 19:615-622 
26. Tabor HK, Risch NJ, Myers RM 2002 Candidate-gene approaches for studying complex genetic traits: practical considerations. Nat Rev Genet 3:391-397

27. Nowotny P, Kwon JM, Goate AM 2001 SNP analysis to dissect human traits. Curr Opin Neurobiol 11:637-641

28. Hirschhorn JN 2005 Genetic approaches to studying common diseases and complex traits. Pediatr Res 57:74R-77R

29. Carlson CS, Eberle MA, Rieder MJ, Yi Q, Kruglyak L, Nickerson DA 2004 Selecting a maximally informative set of single-nucleotide polymorphisms for association analyses using linkage disequilibrium. Am J Hum Genet 74:106-120

30. Luo ZC, Albertsson-Wikland K, Karlberg J 1998 Target height as predicted by parental heights in a population-based study. Pediatr Res 44:563-571

31. Pfäffle R 2006 Genetics of growth in the normal child. European Journal of Endocrinology 155:S27-S33

32. de Ridder MA, Stijnen T, Hokken-Koelega AC 2007 Prediction of adult height in growth-hormone-treated children with growth hormone deficiency. J Clin Endocrinol Metab 92:925-931

33. Reiter EO, Price DA, Wilton P, Albertsson-Wikland K, Ranke MB 2006 Effect of growth hormone $(\mathrm{GH})$ treatment on the near-final height of 1258 patients with idiopathic GH deficiency: analysis of a large international database. J Clin Endocrinol Metab 91:2047-2054

34. Dos Santos C, Essioux L, Teinturier C, Tauber M, Goffin V, Bougneres P 2004 A common polymorphism of the growth hormone receptor is associated with increased responsiveness to growth hormone. Nat Genet 36:720-724

35. Kopchick JJ, Andry JM 2000 Growth hormone (GH), GH receptor, and signal transduction. Mol Genet Metab 71:293-314

36. Rosenzweig SA 2004 What's new in the IGF-binding proteins? Growth Horm IGF Res 14:329-336

37. Baxter RC 2000 Insulin-like growth factor (IGF)-binding proteins: interactions with IGFs and intrinsic bioactivities. Am $\mathrm{J}$ Physiol Endocrinol Metab 278:E967-976

38. Firth SM, Baxter RC 2002 Cellular actions of the insulin-like growth factor binding proteins. Endocr Rev 23:824-854 
39. Godowski PJ, Leung DW, Meacham LR, Galgani JP, Hellmiss R, Keret R, Rotwein PS, Parks JS, Laron Z, Wood WI 1989 Characterization of the human growth hormone receptor gene and demonstration of a partial gene deletion in two patients with Laron-type dwarfism. Proc Natl Acad Sci U S A 86:8083-8087

40. Raz B, Janner M, Petkovic V, Lochmatter D, Eble A, Dattani MT, Hindmarsh PC, Fluck CE, Mullis PE 2008 Influence of growth hormone $(\mathrm{GH})$ receptor deletion of exon 3 and full-length isoforms on $\mathrm{GH}$ response and final height in patients with severe $\mathrm{GH}$ deficiency. $J$ Clin Endocrinol Metab 93:974-980

41. Tauber M, Ester W, Auriol F, Molinas C, Fauvel J, Caliebe J, Nugent T, Fryklund L, Ranke MB, Savage MO, Clark AJ, Johnston LB, HokkenKoelega AC $2007 \mathrm{GH}$ responsiveness in a large multinational cohort of SGA children with short stature (NESTEGG) is related to the exon 3 GHR polymorphism. Clin Endocrinol (Oxf) 67:457-461

42. Binder G, Baur F, Schweizer R, Ranke MB 2006 The d3-growth hormone $(\mathrm{GH})$ receptor polymorphism is associated with increased responsiveness to $\mathrm{GH}$ in Turner syndrome and short small-forgestational-age children. J Clin Endocrinol Metab 91:659-664

43. Pantel J, Machinis K, Sobrier ML, Duquesnoy $P$, Goossens $M$, Amselem S 2000 Species-specific alternative splice mimicry at the growth hormone receptor locus revealed by the lineage of retroelements during primate evolution. J Biol Chem 275:18664-18669

44. Audi L, Esteban C, Carrascosa A, Espadero R, Perez-Arroyo A, Arjona $\mathrm{R}$, Clemente M, Wollmann H, Fryklund L, Parodi LA 2006 Exon 3deleted/full-length growth hormone receptor polymorphism genotype frequencies in Spanish short small-for-gestational-age (SGA) children and adolescents $(n=247)$ and in an adult control population $(n=289)$ show increased fl/fl in short SGA. J Clin Endocrinol Metab 91:5038-5043

45. Stallings-Mann ML, Ludwiczak RL, Klinger KW, Rottman F 1996 Alternative splicing of exon 3 of the human growth hormone receptor is the result of an unusual genetic polymorphism. Proc Natl Acad Sci U S A 93:12394-12399

46. Urbanek M, Russell JE, Cooke NE, Liebhaber SA 1993 Functional characterization of the alternatively spliced, placental human growth hormone receptor. J Biol Chem 268:19025-19032

47. Jorge AA, Marchisotti FG, Montenegro LR, Carvalho LR, Mendonca BB, Arnhold IJ 2006 Growth hormone (GH) pharmacogenetics: influence of $\mathrm{GH}$ receptor exon 3 retention or deletion on first-year growth response and final height in patients with severe $\mathrm{GH}$ deficiency. J Clin Endocrinol Metab 91:1076-1080 
48. Blum WF, Machinis K, Shavrikova EP, Keller A, Stobbe H, Pfaeffle RW, Amselem S 2006 The growth response to growth hormone $(\mathrm{GH})$ treatment in children with isolated $\mathrm{GH}$ deficiency is independent of the presence of the exon 3-minus isoform of the $\mathrm{GH}$ receptor. $J$ Clin Endocrinol Metab 91:4171-4174

49. Carrascosa A, Esteban C, Espadero R, Fernandez-Cancio M, Andaluz P, Clemente M, Audi L, Wollmann H, Fryklund L, Parodi L 2006 The d3/fl-growth hormone $(\mathrm{GH})$ receptor polymorphism does not influence the effect of $\mathrm{GH}$ treatment (66 microg/kg per day) or the spontaneous growth in short non-GH-deficient small-for-gestational-age children: results from a two-year controlled prospective study in 170 Spanish patients. J Clin Endocrinol Metab 91:3281-3286

50. Pilotta A, Mella P, Filisetti M, Felappi B, Prandi E, Parrinello G, Notarangelo LD, Buzi F 2006 Common polymorphisms of the growth hormone $(\mathrm{GH})$ receptor do not correlate with the growth response to exogenous recombinant human $\mathrm{GH}$ in $\mathrm{GH}$-deficient children. J Clin Endocrinol Metab 91:1178-1180

51. Wassenaar MJ, Dekkers OM, Pereira AM, Wit JM, Smit JW, Biermasz NR, Romijn JA 2009 Impact of the exon 3-deleted growth hormone $(\mathrm{GH})$ receptor polymorphism on baseline height and the growth response to recombinant human $\mathrm{GH}$ therapy in GH-deficient (GHD) and non-GHD children with short stature: a systematic review and metaanalysis. J Clin Endocrinol Metab 94:3721-3730

52. Marchisotti FG, Jorge AA, Montenegro LR, Berger K, de Carvalho LR, Mendonca BB, Arnhold IJ 2009 Comparison between weight-based and IGF-I-based growth hormone $(\mathrm{GH})$ dosing in the treatment of children with $\mathrm{GH}$ deficiency and influence of exon 3 deleted $\mathrm{GH}$ receptor variant. Growth Horm IGF Res 19:179-186

53. Binder G, Trebar B, Baur F, Schweizer R, Ranke MB 2007 Homozygosity of the d3-growth hormone receptor polymorphism is associated with a high total effect of $\mathrm{GH}$ on growth and a low BMI in girls with Turner syndrome. Clin Endocrinol (Oxf)

54. Ko JM, Park JY, Yoo HW 2009 Common exon 3 polymorphism of the $\mathrm{GH}$ receptor (GHR) gene and effect of $\mathrm{GH}$ therapy on growth in Korean children with idiopathic short stature (ISS). Clin Endocrinol (Oxf) 70:8287

55. Toyoshima MT, Castroneves LA, Costalonga EF, Mendonca BB, Arnhold IJ, Jorge AA 2007 Exon 3-deleted genotype of growth hormone receptor (GHRd3) positively influences IGF-1 increase at generation test in children with idiopathic short stature. Clin Endocrinol (Oxf) 67:500-504 
56. van der Kaay DC, Hendriks AE, Ester WA, Leunissen RW, Willemsen $\mathrm{RH}$, de Kort SW, Paquette JR, Hokken-Koelega AC, Deal CL 2009 Genetic and epigenetic variability in the gene for IGFBP-3 (IGFBP3): correlation with serum IGFBP-3 levels and growth in short children born small for gestational age. Growth Horm IGF Res 19:198-205

57. Barbosa EJ, Palming J, Glad CA, Filipsson H, Koranyi J, Bengtsson BA, Carlsson LM, Boguszewski CL, Johannsson G 2009 Influence of the exon 3-deleted/full-length growth hormone $(\mathrm{GH})$ receptor polymorphism on the response to $\mathrm{GH}$ replacement therapy in adults with severe $\mathrm{GH}$ deficiency. J Clin Endocrinol Metab 94:639-644

58. Schmid C, Krayenbuehl PA, Bernays RL, Zwimpfer C, Maly FE, Wiesli P 2007 Growth hormone $(\mathrm{GH})$ receptor isoform in acromegaly: lower concentrations of $\mathrm{GH}$ but not insulin-like growth factor-1 in patients with a genomic deletion of exon 3 in the $\mathrm{GH}$ receptor gene. Clin Chem 53:1484-1488

59. Mercado M, Gonzalez B, Sandoval C, Esquenazi Y, Mier F, Vargas G, de los Monteros AL, Sosa E 2008 Clinical and biochemical impact of the d3 growth hormone receptor genotype in acromegaly. J Clin Endocrinol Metab 93:3411-3415

60. Bianchi A, Mazziotti G, Tilaro L, Cimino V, Veltri F, Gaetani E, Pecorini G, Pontecorvi A, Giustina A, De Marinis L 2008 Growth hormone receptor polymorphism and the effects of pegvisomant in acromegaly. Pituitary

61. Bernabeu I, Alvarez-Escola C, Quinteiro C, Lucas T, Puig-Domingo M, Luque-Ramirez $M$, de Miguel-Novoa $P$, Fernandez-Rodriguez $E$, Halperin I, Loidi L, Casanueva FF, Marazuela M The exon 3-deleted growth hormone receptor is associated with better response to pegvisomant therapy in acromegaly. J Clin Endocrinol Metab 95:222-229

62. Johnston LB, Pashankar F, Camacho-Hubner C, Savage MO, Clark AJ 2000 Analysis of the intracellular signalling domain of the human growth hormone receptor in children with idiopathic short stature. Clin Endocrinol (Oxf) 52:463-469

63. Takada D, Ezura $\mathrm{Y}$, Ono S, lino $\mathrm{Y}$, Katayama $\mathrm{Y}$, Xin $\mathrm{Y}$, Wu LL, Larringa-Shum S, Stephenson SH, Hunt SC, Hopkins PN, Emi M 2003 Growth hormone receptor variant (L526I) modifies plasma HDL cholesterol phenotype in familial hypercholesterolemia: intra-familial association study in an eight-generation hyperlipidemic kindred. $A m \mathrm{~J}$ Med Genet A 121A:136-140

64. Ihara K, Inuo M, Kuromaru R, Miyako K, Kohno H, Kinukawa N, Hara T 2007 The Leu544lle polymorphism of the growth hormone receptor gene affects the serum cholesterol levels during $\mathrm{GH}$ treatment in children with GH deficiency. Clin Endocrinol (Oxf) 67:212-217 
65. Ohlsson C, Mohan S, Sjogren K, Tivesten A, Isgaard J, Isaksson O, Jansson JO, Svensson J 2009 The role of liver-derived insulin-like growth factor-I. Endocr Rev 30:494-535

66. Kao PC, Matheny AP, Jr., Lang CA 1994 Insulin-like growth factor-I comparisons in healthy twin children. J Clin Endocrinol Metab 78:310-312

67. Harrela M, Koistinen H, Kaprio J, Lehtovirta M, Tuomilehto J, Eriksson J, Toivanen L, Koskenvuo M, Leinonen P, Koistinen R, Seppala M 1996 Genetic and environmental components of interindividual variation in circulating levels of IGF-I, IGF-II, IGFBP-1, and IGFBP-3. J Clin Invest 98:2612-2615

68. Rosen CJ, Kurland ES, Vereault D, Adler RA, Rackoff PJ, Craig WY, Witte S, Rogers J, Bilezikian JP 1998 Association between serum insulin growth factor-I (IGF-I) and a simple sequence repeat in IGF-I gene: implications for genetic studies of bone mineral density. J Clin Endocrinol Metab 83:2286-2290

69. Weber JL, May PE 1989 Abundant class of human DNA polymorphisms which can be typed using the polymerase chain reaction. Am J Hum Genet 44:388-396

70. Rietveld I, Janssen JA, van Rossum EF, Houwing-Duistermaat JJ, Rivadeneira F, Hofman A, Pols HA, van Duijn CM, Lamberts SW 2004 A polymorphic CA repeat in the IGF-I gene is associated with genderspecific differences in body height, but has no effect on the secular trend in body height. Clin Endocrinol (Oxf) 61:195-203

71. Frayling TM, Hattersley AT, McCarthy A, Holly J, Mitchell SM, Gloyn AL, Owen K, Davies D, Smith GD, Ben-Shlomo Y 2002 A putative functional polymorphism in the IGF-I gene: association studies with type 2 diabetes, adult height, glucose tolerance, and fetal growth in U.K. populations. Diabetes 51:2313-2316

72. Rietveld I, Janssen JA, Hofman A, Pols HA, van Duijn CM, Lamberts SW 2003 A polymorphism in the IGF-I gene influences the age-related decline in circulating total IGF-I levels. Eur J Endocrinol 148:171-175

73. Vaessen N, Janssen JA, Heutink P, Hofman A, Lamberts SW, Oostra BA, Pols HA, van Duijn CM 2002 Association between genetic variation in the gene for insulin-like growth factor-I and low birthweight. Lancet 359:1036-1037

74. Ester WA, Hokken-Koelega AC 2008 Polymorphisms in the IGF1 and IGF1R genes and children born small for gestational age: results of large population studies. Best Pract Res Clin Endocrinol Metab 22:415-431 
75. Arends N, Johnston L, Hokken-Koelega A, van Duijn C, de Ridder M, Savage M, Clark A 2002 Polymorphism in the IGF-I gene: clinical relevance for short children born small for gestational age (SGA). J Clin Endocrinol Metab 87:2720

76. Vaessen N, Heutink $P$, Janssen JA, Witteman JC, Testers L, Hofman A, Lamberts SW, Oostra BA, Pols HA, van Duijn CM 2001 A polymorphism in the gene for IGF-I: functional properties and risk for type 2 diabetes and myocardial infarction. Diabetes 50:637-642

77. Rivadeneira F, Houwing-Duistermaat JJ, Vaessen N, Vergeer-Drop JM, Hofman A, Pols HA, Van Duijn CM, Uitterlinden AG 2003 Association between an insulin-like growth factor I gene promoter polymorphism and bone mineral density in the elderly: the Rotterdam Study. J Clin Endocrinol Metab 88:3878-3884

78. Sweeney C, Murtaugh MA, Baumgartner KB, Byers T, Giuliano AR, Herrick JS, Wolff R, Caan BJ, Slattery ML 2005 Insulin-like growth factor pathway polymorphisms associated with body size in Hispanic and non-Hispanic white women. Cancer Epidemiol Biomarkers Prev 14:1802-1809

79. Cleveland RJ, Gammon MD, Edmiston SN, Teitelbaum SL, Britton JA, Terry MB, Eng SM, Neugut Al, Santella RM, Conway K 2006 IGF1 CA repeat polymorphisms, lifestyle factors and breast cancer risk in the Long Island Breast Cancer Study Project. Carcinogenesis 27:758-765

80. Schildkraut JM, Demark-Wahnefried W, Wenham RM, Grubber J, Jeffreys AS, Grambow SC, Marks JR, Moorman PG, Hoyo C, Ali S, Walther PJ 2005 IGF1 (CA)19 repeat and IGFBP3 -202 A/C genotypes and the risk of prostate cancer in Black and White men. Cancer Epidemiol Biomarkers Prev 14:403-408

81. Hovind $P$, Lamberts $S$, Hop $W$, Deinum J, Tarnow L, Parving $H H$, Janssen JA 2007 An IGF-I gene polymorphism modifies the risk of developing persistent microalbuminuria in type 1 diabetes. Eur $\mathrm{J}$ Endocrinol 156:83-90

82. Yakar S, Rosen CJ, Beamer WG, Ackert-Bicknell CL, Wu Y, Liu JL, Ooi GT, Setser J, Frystyk J, Boisclair YR, LeRoith D 2002 Circulating levels of IGF-1 directly regulate bone growth and density. J Clin Invest 110:771-781

83. Jogie-Brahim S, Feldman D, Oh Y 2009 Unraveling insulin-like growth factor binding protein-3 actions in human disease. Endocr Rev 30:417-437

84. Deal C, Ma J, Wilkin F, Paquette J, Rozen F, Ge B, Hudson T, Stampfer M, Pollak M 2001 Novel promoter polymorphism in insulin-like growth factor-binding protein-3: correlation with serum levels and interaction with known regulators. J Clin Endocrinol Metab 86:1274-1280 
85. Al-Zahrani A, Sandhu MS, Luben RN, Thompson D, Baynes C, Pooley KA, Luccarini C, Munday H, Perkins B, Smith P, Pharoah PD, Wareham NJ, Easton DF, Ponder BA, Dunning AM 2006 IGF1 and IGFBP3 tagging polymorphisms are associated with circulating levels of IGF1, IGFBP3 and risk of breast cancer. Hum Mol Genet 15:1-10

86. Cheng I, DeLellis Henderson K, Haiman CA, Kolonel LN, Henderson BE, Freedman ML, Le Marchand L 2007 Genetic determinants of circulating insulin-like growth factor (IGF)-I, IGF binding protein (BP)-1, and IGFBP-3 levels in a multiethnic population. $J$ Clin Endocrinol Metab 92:3660-3666

87. Jernstrom H, Deal C, Wilkin F, Chu W, Tao Y, Majeed N, Hudson T, Narod SA, Pollak M 2001 Genetic and nongenetic factors associated with variation of plasma levels of insulin-like growth factor-I and insulinlike growth factor-binding protein-3 in healthy premenopausal women. Cancer Epidemiol Biomarkers Prev 10:377-384

88. Morimoto LM, Newcomb PA, White E, Bigler J, Potter JD 2005 Variation in plasma insulin-like growth factor-1 and insulin-like growth factor binding protein-3: genetic factors. Cancer Epidemiol Biomarkers Prev $14: 1394-1401$

89. Ren Z, Cai Q, Shu XO, Cai H, Li C, Yu H, Gao YT, Zheng W 2004 Genetic polymorphisms in the IGFBP3 gene: association with breast cancer risk and blood IGFBP-3 protein levels among Chinese women. Cancer Epidemiol Biomarkers Prev 13:1290-1295

90. Schernhammer ES, Hankinson SE, Hunter DJ, Blouin MJ, Pollak MN 2003 Polymorphic variation at the -202 locus in IGFBP3: Influence on serum levels of insulin-like growth factors, interaction with plasma retinol and vitamin D and breast cancer risk. Int J Cancer 107:60-64

91. Slattery ML, Baumgartner KB, Byers T, Guiliano A, Sweeney C, Herrick J, Curtin K, Murtaugh M, Wolff R 2005 Genetic, anthropometric, and lifestyle factors associated with IGF-1 and IGFBP-3 levels in Hispanic and non-Hispanic white women. Cancer Causes Control 16:1147-1157

92. Silva EG, Slhessarenko N, Arnhold IJ, Batista MC, Estefan V, Osorio MG, Marui S, Mendonca BB $2003 \mathrm{GH}$ values after clonidine stimulation measured by immunofluorometric assay in normal prepubertal children and GH-deficient patients. Horm Res 59:229-233

93. Tanner JM, Whitehouse RH, Takaishi M 1966 Standards from birth to maturity for height, weight, height velocity, and weight velocity: British children, 1965. II. Arch Dis Child 41:613-635

94. Greulich WW PS ed. 1959 Radiographic atlas of skeletal development of the hand and wrist. 
95. Kelly PJ, Stallard N, Whittaker JC 2005 Statistical design and analysis of pharmacogenetic trials. Stat Med 24:1495-1508

96. Jorge AAAIJP 2009 Growth hormone receptor exon 3 isoforms and their implication in growth disorders and treatment. Hormone Research 71 (suppl 2)

97. Ioannidis JP, Ntzani EE, Trikalinos TA, Contopoulos-loannidis DG 2001 Replication validity of genetic association studies. Nat Genet 29:306-309

98. Lohmueller KE, Pearce CL, Pike M, Lander ES, Hirschhorn JN 2003 Meta-analysis of genetic association studies supports a contribution of common variants to susceptibility to common disease. Nat Genet 33:177-182

99. Stochholm K, Gravholt $\mathrm{CH}$, Laursen $\mathrm{T}$, Jorgensen JO, Laurberg P, Andersen M, Kristensen LO, Feldt-Rasmussen U, Christiansen JS, Frydenberg M, Green A 2006 Incidence of GH deficiency - a nationwide study. Eur J Endocrinol 155:61-71

100. Jorge AA, Arnhold IJ 2009 Growth hormone receptor exon 3 isoforms and their implication in growth disorders and treatment. Horm Res 71 Suppl 2:55-63

101. Blum WF, Jenne EW, Reppin F, Kietzmann K, Ranke MB, Bierich JR 1989 Insulin-like growth factor I (IGF-I)-binding protein complex is a better mitogen than free IGF-I. Endocrinology 125:766-772

102. Bright GM, Julius JR, Lima J, Blethen SL 1999 Growth hormone stimulation test results as predictors of recombinant human growth hormone treatment outcomes: preliminary analysis of the national cooperative growth study database. Pediatrics 104:1028-1031

103. Cole TJ, Hindmarsh PC, Dunger DB 2004 Growth hormone (GH) provocation tests and the response to $\mathrm{GH}$ treatment in $\mathrm{GH}$ deficiency. Arch Dis Child 89:1024-1027

104. Rosenbloom AL 1999 A mathematical model for predicting growth response to growth hormone replacement therapy--a useful clinical tool or an intellectual exercise? J Clin Endocrinol Metab 84:1172-1173

105. Radetti G, Buzi F, Cassar W, Paganini C, Stacul E, Maghnie M 2003 Growth hormone secretory pattern and response to treatment in children with short stature followed to adult height. Clin Endocrinol (Oxf) 59:27-33

106. Campbell MJ, Julious SA, Altman DG 1995 Estimating sample sizes for binary, ordered categorical, and continuous outcomes in two group comparisons. BMJ 311:1145-1148 
107. Tae HJ, Luo X, Kim KH 1994 Roles of CCAAT/enhancer-binding protein and its binding site on repression and derepression of acetyl-CoA carboxylase gene. J Biol Chem 269:10475-10484

108. Gebhardt F, Zanker KS, Brandt B 1999 Modulation of epidermal growth factor receptor gene transcription by a polymorphic dinucleotide repeat in intron 1. J Biol Chem 274:13176-13180

109. Clemmons DR 2001 Commercial assays available for insulin-like growth factor I and their use in diagnosing growth hormone deficiency. Horm Res 55 Suppl 2:73-79

110. Milani D, Carmichael JD, Welkowitz J, Ferris S, Reitz RE, Danoff A, Kleinberg DL 2004 Variability and reliability of single serum IGF-I measurements: impact on determining predictability of risk ratios in disease development. J Clin Endocrinol Metab 89:2271-2274

111. Mohan S, Baylink DJ 2002 IGF-binding proteins are multifunctional and act via IGF-dependent and -independent mechanisms. J Endocrinol 175:19-31

112. Zapf $\mathrm{J} 1995$ Physiological role of the insulin-like growth factor binding proteins. Eur J Endocrinol 132:645-654

113. Ernst M, Rodan GA 1990 Increased activity of insulin-like growth factor (IGF) in osteoblastic cells in the presence of growth hormone (GH): positive correlation with the presence of the GH-induced IGF-binding protein BP-3. Endocrinology 127:807-814

114. Conover CA, Clarkson JT, Bale LK 1996 Factors regulating insulin-like growth factor-binding protein-3 binding, processing, and potentiation of insulin-like growth factor action. Endocrinology 137:2286-2292

115. Conover CA, Bale LK, Durham SK, Powell DR 2000 Insulin-like growth factor (IGF) binding protein-3 potentiation of IGF action is mediated through the phosphatidylinositol-3-kinase pathway and is associated with alteration in protein kinase B/AKT sensitivity. Endocrinology 141:3098-3103

116. Chen JC, Shao ZM, Sheikh MS, Hussain A, LeRoith D, Roberts CT, Jr., Fontana JA 1994 Insulin-like growth factor-binding protein enhancement of insulin-like growth factor-I (IGF-I)-mediated DNA synthesis and IGF-I binding in a human breast carcinoma cell line. J Cell Physiol 158:69-78

117. Butt AJ, Martin JL, Dickson KA, McDougall F, Firth SM, Baxter RC 2004 Insulin-like growth factor binding protein-3 expression is associated with growth stimulation of T47D human breast cancer cells: the role of altered epidermal growth factor signaling. J Clin Endocrinol Metab 89:1950-1956 
118. De Mellow JS, Baxter RC 1988 Growth hormone-dependent insulin-like growth factor (IGF) binding protein both inhibits and potentiates IGF-Istimulated DNA synthesis in human skin fibroblasts. Biochem Biophys Res Commun 156:199-204

119. Ramagnolo D, Akers RM, Byatt JC, Wong EA, Turner JD 1994 IGF-Iinduced IGFBP-3 potentiates the mitogenic actions of IGF-I in mammary epithelial MD-IGF-I cells. Mol Cell Endocrinol 102:131-139

120. Bagi CM, DeLeon E, Brommage R, Rosen D, Sommer A 1995 Treatment of ovariectomized rats with the complex of rhIGF-I/IGFBP-3 increases cortical and cancellous bone mass and improves structure in the femoral neck. Calcif Tissue Int 57:40-46

121. Narusawa K, Nakamura T, Suzuki K, Matsuoka Y, Lee LJ, Tanaka H, Seino $Y 1995$ The effects of recombinant human insulin-like growth factor (rhIGF)-1 and rhIGF-1/IGF binding protein-3 administration on rat osteopenia induced by ovariectomy with concomitant bilateral sciatic neurectomy. J Bone Miner Res 10:1853-1864

122. Kupfer SR, Underwood LE, Baxter RC, Clemmons DR 1993 Enhancement of the anabolic effects of growth hormone and insulin-like growth factor I by use of both agents simultaneously. J Clin Invest 91:391-396

123. Conover CA 1991 Glycosylation of insulin-like growth factor binding protein-3 (IGFBP-3) is not required for potentiation of IGF-I action: evidence for processing of cell-bound IGFBP-3. Endocrinology 129:3259-3268

124. Bick T, Hochberg Z, Amit T, Isaksson OG, Jansson JO 1992 Roles of pulsatility and continuity of growth hormone $(\mathrm{GH})$ administration in the regulation of hepatic $\mathrm{GH}$-receptors, and circulating $\mathrm{GH}$-binding protein and insulin-like growth factor-I. Endocrinology 131:423-429

125. Ho KY, Weissberger AJ, Stuart MC, Day RO, Lazarus L 1989 The pharmacokinetics, safety and endocrine effects of authentic biosynthetic human growth hormone in normal subjects. Clin Endocrinol (Oxf) $30: 335-345$

126. Isgaard J, Carlsson L, Isaksson OG, Jansson JO 1988 Pulsatile intravenous growth hormone $(\mathrm{GH})$ infusion to hypophysectomized rats increases insulin-like growth factor I messenger ribonucleic acid in skeletal tissues more effectively than continuous $\mathrm{GH}$ infusion. Endocrinology 123:2605-2610 
127. Moore JH, Lamb JM, Brown NJ, Vaughan DE 2002 A comparison of combinatorial partitioning and linear regression for the detection of epistatic effects of the ACE I/D and PAl-1 4G/5G polymorphisms on plasma PAl-1 levels. Clin Genet 62:74-79

128. Nelson MR, Kardia SL, Ferrell RE, Sing CF 2001 A combinatorial partitioning method to identify multilocus genotypic partitions that predict quantitative trait variation. Genome Res 11:458-470

129. Hirschhorn JN 2009 Genomewide association studies--illuminating biologic pathways. N Engl J Med 360:1699-1701 
Apêndices 


\section{Modelos Matemáticos para Previsão de Resposta ao Tratamento com Hormônio de Crescimento}

\begin{abstract}
RESUMO
Modelos preditivos de crescimento são algoritmos derivados de análises de regressão linear múltipla contendo variáveis que influenciam o crescimento em resposta ao tratamento com $\mathrm{GH}$ em determinado grupo de indivíduos durante determinado período. A partir do conhecimento da importância relativa de cada variável, são geradas fórmulas matemáticas que permitem obter a medida objetiva do potencial de crescimento de cada indivíduo em resposta ao tratamento com GH em diferentes situações. Tais algoritmos podem, portanto, ser utilizados como ferramentas para a decisão fundamentada em evidência das estratégias de tratamento com GH a serem utilizadas em diferentes crianças com baixa estatura, a fim de se obter o máximo de custoefetividade com a menor dose cumulativa possível. Já foram desenvolvidos diversos modelos de previsão de resposta ao tratamento com $\mathrm{GH}$ em diferentes causas de baixa estatura, porém estes ainda apresentam baixa aplicabilidade clínica por causa do baixo poder preditivo e da baixa precisão da previsão, o que tem gerado crescente interesse pela incorporação de variáveis adicionais, como marcadores bioquímicos e genéticos que possam melhorar a acurácia da previsão e, assim, permitir que, no futuro, o tratamento com GH possa ser individualizado conforme as necessidades específicas de cada criança. (Arq Bras Endocrinol Metab 2008; 52/5:839-849)
\end{abstract}

Descritores: Hormônio do crescimento/deficiência; Hormônio do crescimento/farmacologia; Hormônio do crescimento/uso terapêutico; Farmacogenética; Nanismo; Insuficiência de crescimento

\begin{abstract}
Mathematical Models for Predicting Growth Responses to Growth Hormone Replacement Therapy.

Growth prediction models are algorithms derived from multiple regression analyses including variables that influence growth responses to $\mathrm{GH}$ therapy in a defined group of subjects over a defined period of time. Mathematical equations can be derived from the knowledge acquired with the relative importance of each variable, which provide objective measurements of each subject's growth potential in response to GH therapy on different situations. Therefore, these equations can be used as tools to improve evidence-based decision regarding to growth promoting treatment strategies to be used in each child, optimizing cost-effectiveness with the lowest cumulative GH dose. Several models have already been developed to predict growth responses to $\mathrm{GH}$ for different short stature causes, but they still have low clinical usefulness, due to their low predictive power and low prevision accuracy. This has lead to a growing interest in the addition of new variables, such as biochemical or genetic markers, which could improve prevision accuracy and then, in the future, may allow GH therapy individualization according to the specific needs of each child. (Arq Bras Endocrinol Metab 2008; 52/5:839-849)
\end{abstract}

Keywords: Growth hormone/deficiency; Growth hormone/pharmacology; Growth hormone/therapeutic use; Pharmacogenetics; Dwarfism; Failure to thrive

\section{revisão}

\author{
EVERLAyNy F. COSTALONGa \\ ALEXANDER A. L. JORGE \\ BERENICE B. MENDONÇA \\ IVO J. P. ARNHOLD
}

Unidade de Endocrinologia do Desenvolvimento e Laboratório de Hormônios e Genética Molecular LIM/42, Disciplina de Endocrinologia e Metabologia do Hospital das Clínicas da Faculdade de Medicina da Universidade de São Paulo (FMUSP), SP, Brasil. 


\section{INTRODUÇÃO}

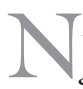
A DÉCADA DE 1950, o hormônio do crescimento growth hormone $(\mathrm{GH})$, obtido de hipófise de cadáver, foi pela primeira vez utilizado para tratar a baixa estatura de crianças com deficiência de GH (DGH). Na década de 1980, com o advento do hormônio de crescimento recombinante humano, houve crescente aumento do uso deste para pacientes com DGH, assim como com outras causas de baixa estatura. Hoje, cerca de 100 mil crianças são tratadas com $\mathrm{GH}$ em todo o mundo, mas a dose utilizada permanece largamente empírica. Nos Estados Unidos, por exemplo, doses diárias entre 0,025 e $0,050 \mathrm{mg} / \mathrm{kg} /$ dia são comumente usadas, enquanto na Europa as doses variam de 0,025 a $0,035 \mathrm{mg} / \mathrm{kg} /$ dia e no Japão não passam de 0,025 $\mathrm{mg} / \mathrm{kg} /$ dia (1). Ou seja, apesar de a extensa experiência de 40 anos de uso de GH para o tratamento de diferentes causas de baixa estatura, ainda não existe consenso quanto ao regime de tratamento ideal, e, dessa forma, a estratégia terapêutica se mantém inalterada, fundamentada em doses fixas, arbitrárias e ajustadas somente pelo peso, sem levar em consideração os diferentes graus de sensibilidade individual ao hormônio. Como resultado, o que se observa é ampla variabilidade de resposta ao tratamento, mesmo quando se comparam crianças da mesma categoria diagnóstica e tratadas segundo as mesmas recomendações (Figura 1).

Em virtude dessas observações, a necessidade de individualização do tratamento com GH conforme a sensibilidade e as características específicas de cada criança tem sido crescentemente reconhecida. Como passo inicial, rumo à individualização, inúmeros traba-
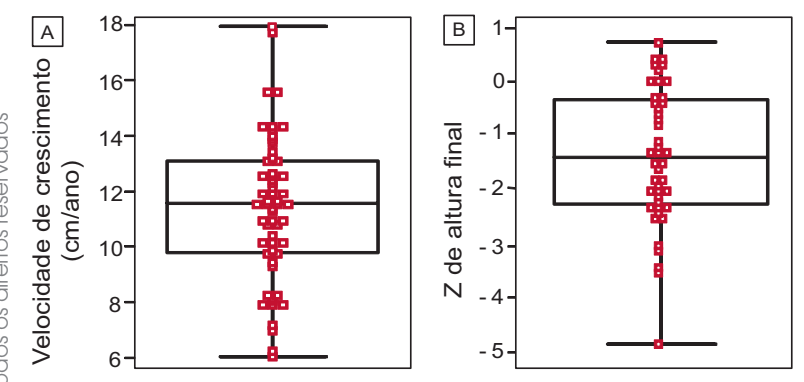

Figura 1. Variabilidade de resposta ao tratamento com $\mathrm{GH}$ em crianças com DGH. A) Velocidade de crescimento no primeiro ano de tratamento com GH de crianças pré-púberes com DGH; B) Z de altura final de crianças com DGH tratadas com $\mathrm{GH}$ por, pelo menos, três anos. lhos têm se dedicado ao estudo dos fatores determinantes da capacidade de resposta ao tratamento com $\mathrm{GH}$ nas diferentes causas de baixa estatura. A partir do conhecimento dessas variáveis e da importância relativa de cada uma, pode-se prever a resposta de crescimento que será obtida consoante a dose de GH utilizada em determinado indivíduo. De acordo com a previsão, o tratamento pode ser otimizado, a fim de se obter o máximo de crescimento com o mínimo de custos e riscos. Foi com esse objetivo que surgiram os chamados modelos preditivos de resposta ao tratamento com GH, que serão abordados nessa revisão, buscando proporcionar uma visão geral sobre os avanços até o momento no conhecimento dos fatores determinantes de resposta ao tratamento com $\mathrm{GH}$ (sobretudo na DGH) e os desafios a serem superados nos próximos anos para que essa modalidade terapêutica possa beneficiar, de maneira efetiva e segura, um número crescente de indivíduos.

\section{DEFINIÇÃO DE MODELOS PREDITIVOS}

Modelos preditivos de resposta ao tratamento com GH são algoritmos derivados de análises de regressão linear múltipla contendo variáveis que influenciam o crescimento em resposta ao tratamento com GH em determinado grupo de indivíduos durante um período definido (2). A partir do conhecimento da importância relativa de cada variável, são geradas fórmulas matemáticas que permitam obter a medida objetiva do potencial de crescimento de cada indivíduo em resposta ao tratamento com $\mathrm{GH}$ em diferentes situações.

\section{APLICABILIDADE CLÍNICA}

Os modelos preditivos de crescimento em resposta ao $\mathrm{GH}$ podem ser usados para:

- Melhor individualização do tratamento, ou seja, ajustar o tratamento conforme a sensibilidade individual, determinando assim a dose de $\mathrm{GH}$ ideal para se atingir a estatura-alvo de determinada criança de maneira rápida, efetiva e segura $(2,3)$.

- Permitir o desenvolvimento de estratégias de tratamento que utilizem a menor dose cumulativa possível, usando doses maiores nos momentos mais indicados pelos modelos preditivos (2) (para exemplo prático dessa aplicabilidade, consultar o site www.growthpredictions.org). 
- Minimizar possíveis riscos do tratamento.

- Reduzir custos financeiros.

- Identificar, desde o início, os possíveis "bons e maus respondedores", dessa forma auxiliando na tomada de decisão quanto ao início do tratamento.

- Propiciar aos pacientes, pais e agentes de saúde expectativas mais realistas de resposta do início ao final do tratamento $(2,3)$, a fim de prover base segura para encorajar ou desencorajar a continuação da terapia, fundamentando-se numa previsão acurada e não em um "simples desejo" do indivíduo.

- Monitorizar o tratamento passo a passo, de maneira que a observação de discrepâncias entre a resposta observada e a prevista ou de reduções inesperadas da resposta possam permitir a detecção precoce da presença de outros fatores interferentes, como falta de aderência ou doença endócrina ou não-endócrina subjacente não diagnosticadas $(2,3)$.

\section{CARACTERÍSTICAS DE UM MODELO PREDITIVO IDEAL}

Um modelo preditivo ideal deve ser confiável, eficiente e prático, a fim de que possa ser utilizado na prática clínica diária.

Objetivando confiabilidade dos resultados, o modelo preditivo deve ser desenvolvido a partir de dados de uma população ampla e representativa de uma categoria diagnóstica específica (DGH, síndrome de Turner (ST), baixa estatura idiopática etc.), com critérios de inclusão bem definidos que permitam a seleção da casuística o mais homogênea possível para que possa representar de maneira adequada os fatores determinantes de resposta naquele grupo específico.

Quanto às propriedades que, em última análise, determinam a aplicabilidade clínica do algoritmo para predição da resposta individual ao tratamento incluem:

- Alto poder preditivo $\left(\mathrm{R}^{2}\right)$ - significa ser capaz de explicar o grande percentual da variação de resposta que ocorre em determinada população (por exemplo, a previsão com $\mathrm{R}^{2}$ de 0,9 é capaz de explicar $90 \%$ da variabilidade que ocorre naquele grupo).

- Alta precisão da previsão - significa prever com baixo desvio-padrão (por exemplo, prever a velocidade de crescimento (VC) de $11 \mathrm{~cm} /$ ano com desvio-padrão de $0,4 \mathrm{~cm}$ significa prever que a $\mathrm{VC}$ será entre 10,2 e 11,8 (média \pm 2 DP) com 95\% de confiança).

- Utilizar para a previsão dados que estejam disponíveis já no início do tratamento, para que possam orientar a dose a ser utilizada desde a introdução do GH.

- Incluir dose de GH como variável, o que é essencial para que a resposta ao tratamento seja ajustada a partir da adequação deste fator (3).

- Ser "período específico" - como as condições que afetam o crescimento diferem conforme a idade, a puberdade e o tempo de tratamento, um bom modelo preditivo deve corresponder a séries de algoritmos descrevendo o crescimento em períodos seqüenciais, tipicamente para cada ano de tratamento ou, pelo menos, diferentes para os períodos pré e pós-puberais (3).

- Ser validado numa população independente e calibrado para valores extremos (2).

- Ser prático, simples, objetivo e integrado a um programa de informática de fácil utilização $(2,3)$.

- Ser regularmente atualizado para refletir mudanças das características clínicas e práticas de tratamento com GH (2).

\section{VALIDAÇÃO E CALIBRAÇÃO}

É importante destacar que o poder preditivo descrito para os diferentes modelos preditivos refere-se à população a partir da qual foi gerado o algoritmo, sendo provavelmente diferente quando aplicado a um segundo grupo de indivíduos. Além disso, sabe-se que os modelos preditivos apresentam performance aquém da esperada quando aplicados de maneira individual, mesmo em indivíduos da mesma população (4). Análises estatísticas recentes demonstram que, em muitos casos, isso ocorre por causa do chamado overfitting, fenômeno comum quando tanto a seleção dos preditores quanto a estimativa dos coeficientes são guiados pelo mesmo banco de dados, resultando "supervalorização" desses parâmetros e, conseqüentemente, em previsões muito extremas (5).

Portanto, para a válida aplicação de um modelo preditivo a novos indivíduos, as previsões devem ser não só validadas em uma segunda população, mas também calibradas para reduzir o overfitting. Para isso, o modelo preditivo é aplicado a uma população diferente daquela que originou os dados para a construção do algoritmo, verificando-se: a) qual o nível de precisão da 
previsão quando aplicado a um grupo de indivíduos diferente daquele usado para a análise de regressão linear múltipla; b) qual a acurácia da previsão quando aplicada de modo individual; c) se a aplicação deste modelo pode ser feita da forma como foi determinado originalmente ou por meio de ajustes matemáticos específicos.

As diferenças entre o crescimento observado e o predito em cada indivíduo podem ser expressas na forma do studentized residual, representado pela fórmula a seguir:

$\begin{aligned} & \text { Studentized } \\ & \text { residual }\end{aligned}=\frac{\text { crescimento observado }- \text { predito }}{\text { Erro-padrão (SE) calculado para cada indivíduo }}$

Este é um cálculo comparável ao do escore de desvio-padrão ("Z"). Valores ao redor de zero indicam resposta compatível com a esperada pelo modelo preditivo (2). A partir deste cálculo podem ser construídas curvas de calibração que representam as diferenças entre o observado e o previsto em cada criança, indicando, dessa forma, o nível de acurácia do modelo preditivo quando aplicado a um novo grupo de indivíduos.

\section{CARACTERÍSTICAS GERAIS}

\section{Classificação}

Como comentado anteriormente, um modelo preditivo ideal deve ser diagnóstico e período-específico. Assim, os modelos preditivos podem ser classificados quanto a:

\section{Categoria diagnóstica}

Já existem modelos disponíveis para previsão da resposta ao tratamento com GH em DGH (5-10), ST (11-15), baixa estatura idiopática $(14,16,17)$ e nascidos pequenos para a idade gestacional (PIGs) $(18,19)$.

\section{Período do crescimento estudado}

Em pacientes com DGH, por exemplo, existem estudos avaliando os fatores preditivos especificamente em indivíduos menores de 3 anos de idade (20), em crianças de 1 a 8 anos (pré-púberes) (10) e durante o período puberal (21).

\section{Variáveis utilizadas para a previsão}

Em termos gerais, as variáveis analisadas na maior parte dos modelos desenvolvidos até o momento foram relacionadas a: a) nascimento - peso, altura, sexo; b) potencial genético - altura dos pais; c) início do tratamento - idade, altura, peso, estádio puberal; d) parâmetros laboratoriais - sobretudo pico máximo de GH em testes de estímulo; e) modalidade terapêutica - dose, freqüência das injeções, duração do tratamento.

\section{MODELOS PREDITIVOS EM CRIANÇAS COM DGH}

Os modelos de predição de resposta de crescimento ao tratamento com $\mathrm{GH}$ em crianças com $\mathrm{DGH}$ podem ser classificados de maneira simplificada em modelos de predição para a resposta a curto prazo (VC) e ganho em $\mathrm{Z}$ de altura no primeiro ano de tratamento) e a longo prazo ( $\mathrm{Z}$ de altura final, com e sem ajuste pelo alvo e ganho em $\mathrm{Z}$ de altura total ao longo do tratamento).

As principais variáveis que demonstraram influenciar a resposta ao tratamento com $\mathrm{GH}$ a curto e a longo prazo em crianças com DGH encontram-se resumidamente descritas na Tabela 1 .

Tabela 1. Fatores determinantes de resposta ao tratamento com GH a curto e a longo prazos em crianças com DGH*.

\begin{tabular}{|c|c|}
\hline $\begin{array}{l}\text { Resposta a curto prazo } \\
\left.\text { ( } 1^{\circ} \text { ano }\right)\end{array}$ & $\begin{array}{l}\text { Resposta a longo prazo } \\
\text { (altura final) }\end{array}$ \\
\hline Pico de GH máximo em testes de estímulo $(10,20,22-24)$ & Resposta de crescimento no $1^{\circ}$ ano $(5,7,9,25)$ \\
\hline Idade cronológica no início do tratamento $(10,20,22-24)$ & Estatura-alvo $(5,8,9,25)$ \\
\hline $\begin{array}{l}Z \text { de altura inicial com }(10) \text { e sem }(23,24) \\
\text { ajuste para estatura-alvo }\end{array}$ & Pico de GH máximo em testes de estímulo $(5,8,9,25)$ \\
\hline Estatura-alvo $(20,22-24)$ & $Z$ de altura inicial $(5,7,8,25,26)$ \\
\hline Dose utilizada $(1,10,20,22,27-29)$ & Duração do tratamento $(7-9,25)$ \\
\hline$Z$ de peso no início do tratamento $(10,20)$ & Idade cronológica no início do tratamento $(7,9)$ \\
\hline$Z$ de peso ao nascer $(10,20)$ & Sexo $(5,7,8)$ \\
\hline Número de injeções/semana $(23,31)$ & $\begin{array}{l}\text { Presença de deficiência hormonal múltipla }(5,25) \\
\text { Puberdade espontânea ou induzida }(17,25,26,30) \\
\text { Idade ou altura do início da puberdade }(6,8,32)\end{array}$ \\
\hline
\end{tabular}




\section{Modelos de previsão de resposta a curto prazo (primeiro ano de tratamento)}

Diversos estudos procuraram identificar os fatores preditivos de resposta ao tratamento com GH em crianças com DGH no primeiro ano de tratamento (10,20,22-24).

Entre estes, destaca-se o trabalho desenvolvido por Ranke e cols. (10), 1999, envolvendo 593 crianças do banco de dados KIGS (Pfizer International Growth Study Database), exclusivamente pré-púberes, com DGH idiopática diagnosticada por pico máximo de GH $<10 \mathrm{ng} / \mathrm{ml}$ em pelos menos dois testes de estímulo e tratadas exclusivamente com $\mathrm{GH}$ recombinante na dose média de 0,6 UI $/ \mathrm{kg} / \mathrm{semana}$. O estudo se destacou em relação aos trabalhos prévios em virtude da ampla casuística utilizada e por ter restringido a análise a pacientes recebendo pelo menos 6 injeções/semana e que tinham registros de $\mathrm{VC}$ aferida com 11 a 13 meses de tratamento.

A variável de maior importância para a VC no primeiro ano de tratamento foi o logaritmo natural da resposta máxima de $\mathrm{GH}$ em testes provocativos, a qual se demonstrou inversamente relacionada à VC. Ou seja, quanto maior a gravidade da DGH, melhor a resposta ao tratamento no primeiro ano. Além disso, a VC no primeiro ano foi inversamente relacionada à idade cronológica e ao $\mathrm{Z}$ de altura no início do tratamento (ajustado para a estatura-alvo); e positivamente correlacionada ao $\mathrm{Z}$ peso inicial, logaritmo natural da dose semanal e $\mathrm{Z}$ de peso ao nascer. A contribuição relativa de cada um desses fatores identificada pela análise de regressão linear múltipla está ilustrada na Tabela 2.

Tabela 2. Modelo de regressão linear múltipla para predição da VC no primeiro ano de tratamento com $\mathrm{GH}$ em crianças com DGH (com base nos dados do KIGS, adaptado de Ranke e cols., JCEM, 1999) (10).

\begin{tabular}{lcc}
\hline Variável de predição & Coeficiente & Rank \\
\hline Ln do pico $\mathrm{GH}$ máximo $(\mu \mathrm{g} / \mathrm{dl})$ & $-1,37$ & 1 \\
\hline Idade cronológica inicial & $-0,32$ & 2 \\
\hline $\begin{array}{l}\text { Z de altura inicial - Z da } \\
\text { midparental heigth }(\mathrm{MPH})\end{array}$ & $-0,4$ & 3 \\
Z de peso inicial & 0,29 & 4 \\
Ln da dose (Ul/kg/semana) & 1,62 & 5 \\
\hline Z do peso ao nascer & 0,32 & 6 \\
Constante & \multicolumn{3}{c}{14,55} \\
R & \multicolumn{3}{c}{0,61} \\
DP & \multicolumn{3}{c}{1,46} \\
\hline Ln= Log natural:Z da midparental height $(\mathrm{MPH})=(\mathrm{Z}$ de altura do pai + Z de
\end{tabular}

altura da mãe) $\div$ 1,61; DP = desvio-padrão.
A equação que descreve a predição da VC primeiro ano a partir da análise mencionada é:

$$
\begin{aligned}
\text { VC predita }= & 14,55+(-1,37 \times \mathrm{Ln} \text { GHmáx })+(-0,32 \\
& \times \mathrm{IC} \text { inicial })+(0,32 \times \mathrm{Z} \text { peso ao nas- } \\
& \text { cer })+(1,62 \times \mathrm{Ln} \text { dose } \mathrm{GH})+(-0,4 \times \\
& \mathrm{Z} \text { altura inicial }-\mathrm{Z} \mathrm{MP})+(0,29 \times \mathrm{Z} \\
& \text { peso inicial })( \pm 1,46 \mathrm{~cm} / \text { ano })
\end{aligned}
$$

Como descrito na Tabela 2, o modelo explicava $\left(\mathrm{R}^{2}\right) 61 \%$ da variabilidade da VC no primeiro ano de tratamento com desvio-padrão de $1,46 \mathrm{~cm}$. De modo interessante, os autores construíram um segundo modelo em que o pico de GH máximo em testes de estímulo era excluído da equação; e observaram que o modelo resultante apresentava menor poder preditivo $(45 \%)$, maior desvio-padrão $(1,76 \mathrm{~cm})$ e tendência a "subprever" a resposta de crescimento das crianças com DGH mais grave (pico GH máx $<5 \mathrm{ng} / \mathrm{ml}$, sobretudo $<3 \mathrm{ng} / \mathrm{ml}$ ). Tal observação sugere que a importância do pico de $\mathrm{GH}$ como preditor de resposta seja ainda mais evidente quando se comparam indivíduos com pico de GH máximo muito baixo - provavelmente os "verdadeiros DGH" - e os portadores de "DGH parcial", provavelmente incluindo alguns pacientes sem deficiência real de GH. Assim, em razão de os primeiros apresentarem respostas de crescimento nitidamente superiores aos últimos, a tentativa de uso de um modelo comum aos dois grupos sem considerar o que os diferencia com certa segurança - que é o pico de GH em testes de estímulo - resulta previsões equivocadas no grupo com verdadeira DGH, quando comparadas aos casos de baixa estatura com etiopatogenia não claramente relacionada à DGH.

\section{Modelos de previsão de resposta a longo prazo (altura final)}

Os trabalhos avaliando a resposta ao tratamento com $\mathrm{GH}$ em termos de altura final são mais numerosos e também mais heterogêneos, com alguns incluindo somente pacientes com DGH isolada $(6,7)$ e outros incluindo pacientes com deficiências hipofisárias múltiplas $(5,8,9,25)$, por exemplo.

Destaca-se o modelo desenvolvido por Ridder e cols. (5), 2007, que se diferencia dos demais pela primorosa análise estatística e pelo cuidado de construir modelos diferentes conforme a presença ou não da pu- 
berdade no primeiro ano de tratamento. Além disso, se propõe a construir um modelo preditivo do $\mathrm{Z}$ de altura final que possa ser aplicável no início do tratamento, ou seja, sem dados retrospectivos, como VC no primeiro ano e variáveis relacionadas à puberdade, os quais são utilizados na maioria dos modelos preditivos de altura final, dessa forma impedindo sua aplicabilidade clínica no início do tratamento.

O modelo envolvendo exclusivamente pacientes pré-púberes do início ao final do primeiro ano de tratamento e utilizando apenas dados disponíveis no início do tratamento pode ser descrito pela equação a seguir e pela Tabela 3:

$\begin{aligned} \mathbf{Z} \text { de altura final }= & 1,186+1,021 \times \mathrm{Z} \text { altura inicial }+ \\ & 0,077 \times(\mathrm{Z} \text { altura inicial })^{2}+0,264 \\ & \times \mathrm{Z} \text { da estatura-alvo }-0,148 \times \mathrm{Ln} \\ & (\max \mathrm{GH})+0,260 \times \text { sexo }+ \\ & 0,302 \times \mathrm{DHM}-0,047 \times \text { idade } \\ & \text { óssea inicial }( \pm 0,84 \mathrm{DP})\end{aligned}$

Este modelo foi capaz de prever $37 \%$ da variabilidade de resposta em termos de $\mathrm{Z}$ de altura final com desvio-padrão e $\pm 0,84 \mathrm{DP}$.

\section{MODELOS PREDITIVOS EM OUTRAS CAUSAS DE BAIXA ESTATURA}

Embora se tenha optado, por questões didáticas, por não entrar em detalhes sobre os modelos preditivos de resposta ao tratamento com $\mathrm{GH}$ nas baixas estaturas de etiologia diferente da DGH, é válida a análise comparativa breve dos fatores que se demonstraram importantes na determinação de resposta ao $\mathrm{GH}$ em diferentes causas de baixa estatura.

Enquanto na DGH o preditor mais importante foi o grau de DGH, nos indivíduos com ST ou nascidos pequenos para a idade gestacional, por exemplo, o fator mais importante foi a dose de GH utilizada, seguida pela idade cronológica do início do tratamento. A título de ilustração, a Tabela 4 faz uma análise comparativa do grau de importância de cada variável na predição da VC no primeiro ano de tratamento com GH em indivíduos com DGH, ST e PIGs, segundo os modelos construídos com base no banco de dados do KIGS. Observe que, a partir das variáveis analisadas, pode-se explicar $61 \%$ da variabilidade de resposta ao tratamento com $\mathrm{GH}$ em crianças com DGH, 46\% em crianças com ST e $52 \%$ em crianças nascidas PIG. A maior capacidade preditiva em crianças com DGH já seria esperada, por se tratar de um grupo teoricamente mais homogêneo em termos de fisiopatologia e de tratamento da causa da baixa estatura em relação aos demais grupos diagnósticos.

\section{EXEMPLOS DE APLICAÇÃO DE MODELOS PREDITIVOS}

A título de ilustração, considere-se uma criança que no momento do diagnóstico de DGH apresente as seguintes características: sexo masculino; DGH isolada; idade cronológica $=6$ anos; idade óssea $=3$ anos; GH máximo obtido em testes de estímulo $=2,0(\mathrm{ng} / \mathrm{ml}) ; \mathrm{Z}$ da

Tabela 3. Modelo de regressão linear múltipla para predição do Z de altura final após tratamento com GH em crianças com DGH, usando apenas dados disponíveis já no início do tratamento (adaptado de Ridder e cols., JCEM, 2007) (5).

\begin{tabular}{|c|c|c|c|}
\hline Variável de predição & Coeficiente & p & $\mathbf{R}^{2}$ parcial \\
\hline Z de altura inicial & 1,902 & $<0,0001$ & 0,239 \\
\hline$(Z \text { de altura inicial })^{2}$ & 0,082 & 0,02 & \\
\hline Z da estatura-alvo & 0,282 & $<0,0001$ & 0,086 \\
\hline Ln do pico de GH máximo (ng/ml) & $-0,158$ & 0,02 & 0,022 \\
\hline $\operatorname{Sexo}(0=$ masc $. / 1=$ fem. $)$ & 0,278 & 0,01 & 0,022 \\
\hline Deficiência hipofisária múltipla $(\mathrm{DHM})(0$ = não/1 = sim) & 0,323 & 0,01 & 0,023 \\
\hline Idade óssea inicial (anos) & $-0,051$ & 0,003 & 0,031 \\
\hline Constante & 1,399 & 0,006 & \\
\hline $\mathbf{R}^{2}$ & & \multicolumn{2}{|c|}{0,37} \\
\hline DP & & \multicolumn{2}{|c|}{0,84} \\
\hline
\end{tabular}


Tabela 4. Análise comparativa das variáveis determinantes da VC no primeiro ano de tratamento com GH em indivíduos com DGH, ST e nascidos PIGs, segundo modelos do KIGS.

\begin{tabular}{|c|c|c|c|c|c|c|}
\hline \multirow[t]{2}{*}{ Variáveis de predição } & \multicolumn{2}{|c|}{ DGH } & \multicolumn{2}{|c|}{ ST } & \multicolumn{2}{|c|}{ PIG } \\
\hline & Coeficiente & Rank & Coeficiente & Rank & Coeficiente & Rank \\
\hline Pico de GH máximo & $-1,37$ & 1 & - & - & - & - \\
\hline Dose de GH & 1,62 & 5 & 2,2 & 1 & 56,5 & 1 \\
\hline Idade inicial & $-0,32$ & 2 & $-0,3$ & 2 & $-0,3$ & 2 \\
\hline $\begin{array}{l}\text { Z de altura ajustado para o Z da } \\
\text { estatura-alvo }\end{array}$ & $-0,4$ & 3 & $-0,2$ & 5 & - & - \\
\hline Z da MPH & - & - & - & - & 0,11 & 4 \\
\hline$Z$ de peso inicial & 0,29 & 4 & 0,4 & 3 & 0,3 & 3 \\
\hline$Z$ de peso ao nascer & 0,32 & 6 & - & - & - & - \\
\hline $\mathrm{R}^{2}$ & \multicolumn{2}{|c|}{0,61} & \multicolumn{2}{|c|}{0,46} & \multicolumn{2}{|c|}{0,52} \\
\hline DP & \multicolumn{2}{|c|}{1,5} & \multicolumn{2}{|c|}{1,3} & \multicolumn{2}{|c|}{1,3} \\
\hline
\end{tabular}

$\mathrm{DP}=$ desvio-padrão.

altura atual $=-4,2 \mathrm{DP} ; \mathrm{Z}$ de peso atual $=+1 \mathrm{DP} ; \mathrm{Z}$ da $\mathrm{MPH}=-0,15 \mathrm{DP} ; \mathrm{Z}$ da estatura-alvo $=-0,20 \mathrm{DP} ; \mathrm{Z}$ do peso ao nascer $=+0,2 \mathrm{DP}$.

Utilizando a dose de $\mathrm{GH}$ de $0,1 \mathrm{UI} / \mathrm{kg} / \mathrm{dia}(=0,7$ $\mathrm{UI} / \mathrm{kg} / \mathrm{semana}$ ), qual seria a VC do primeiro ano e a altura final esperadas?

Utilizando como modelo de previsão para a VC no primeiro ano de tratamento, a equação desenvolvida por Ranke e cols. (11), 1999, teríamos:

$\begin{aligned} \text { VC } 1^{\circ} \text { ano esperada }= & 14,55+(-1,37 \times \operatorname{Ln} 2)+ \\ & (-0,32 \times 6)+(0,32 \times 0,2)+ \\ & (1,62 \times \operatorname{Ln} 0,7)+\{-0,4 \times \\ & {[(-4,2)-(-0,15)]\}+(0,29 \times} \\ & 11)=13,1 \pm 1,46 \mathrm{~cm} / \text { ano }\end{aligned}$

Já para a previsão do $\mathrm{Z}$ de altura final, se utilizar o modelo de Ridder e cols. (5), 2007, o que se destaca por ser aplicável no início do tratamento utilizando apenas parâmetros disponíveis já no momento do diagnóstico:

$$
\begin{aligned}
\mathrm{Z} \text { de altura final esperado }= & 1.186+1,021 \times(-4,2)+ \\
& 0,077 \times(-4,2)^{2}+0,264 \\
& \times(-0,2)-(0,148 \times \mathrm{Ln} \\
& 2)+(0,260 \times 0)+(0,302 \\
& \times 0)-(0,047 \times 3)=-2,0 \\
& \pm 0,84 \mathrm{DP}
\end{aligned}
$$

\section{ANÁLISE CRÍTICA DOS MODELOS PREDITIVOS ATUAIS}

Vieses de seleção da casuística para estudo

Ao se analisar os resultados de estudos referentes ao tratamento com GH, é importante considerar que a maioria deles foi desenvolvida com base em grandes bancos de dados de registros nacionais e internacionais, estando sujeitos a inerente heterogeneidade da amostra (25). Além disso, os critérios diagnósticos utilizados na maior parte das vezes - pico de GH máximo em testes de estímulo $<10 \mathrm{ng} / \mathrm{ml}$ - são arbitrários, inespecíficos $(33,34)$, provavelmente inadequados para os ensaios monoclonais atuais (28), além de não necessariamente levarem em consideração os critérios clínicos e auxológicos sabidamente importantes para a definição do diagnóstico de DGH.

Sendo assim, diversos autores $(8,23,25,34-36)$ têm apontado evidências de que uma proporção considerável de indivíduos considerados como tendo DGH nesses estudos apresentem na verdade condições como baixa estatura idiopática ou retardo constitucional do crescimento e puberdade, o que prejudica a interpretação dos dados levantados e, conseqüentemente, a qualidade da previsão de resposta. Uma dessas evidências é a alta taxa de não-confirmação da DGH quando os indivíduos são retestados na idade adulta (37-39). Outra é a forte correlação observada entre o pico máximo de resposta do $\mathrm{GH}$ em testes de estímulo e a resposta ao tratamento com $\mathrm{GH}$, sobretudo no primeiro ano de 
tratamento. Afinal, é indiscutível que pacientes com DGH verdadeira apresentam resposta ao tratamento com GH obviamente superior à de crianças com baixa estatura idiopática e DGH “questionável” (35); e que o pico máximo de $\mathrm{GH}$ é um dos parâmetros que mais bem refletem a presença ou não de $\mathrm{DGH}$ verdadeira nesses indivíduos $(8,17,35,36)$.

\section{Baixo poder preditivo e baixa precisão da previsão}

Note-se que há diferença entre conhecer os fatores determinantes de resposta ao tratamento com GH e desenvolver um modelo preditivo que possa ser utilizado na prática clínica para o ajuste da estratégia terapêutica. Apesar de já terem sido identificados diversos fatores determinantes de resposta ao tratamento com GH, a aplicabilidade clínica deste conhecimento ainda é limitada pelo baixo poder preditivo e o amplo desvio-padrão com que a previsão é feita (Tabela 5), o que desencoraja sua utilização na prática diária.

$\mathrm{O}$ baixo poder preditivo $\left(\mathrm{R}^{2}\right)$ observado sugere que fatores determinantes importantes ainda estejam por ser identificados; e dessa forma tem sido crescente o número de trabalhos buscando identificar outras variáveis, como parâmetros bioquímicos [IGF1, IGFBP3, marcadores de remodelação óssea (24)] e marcadores genéticos que possam refletir, de modo adicional, a sensibilidade ao tratamento com GH.

Além disso, não basta que o modelo tenha boa capacidade preditiva para que seja aplicável clinicamente: se o desvio-padrão for alto (baixa precisão), o algoritmo representa essencialmente a "descrição" das variáveis que se correlacionam à resposta ao tratamento e não permite sua utilização na prática clínica de maneira individual. No exemplo descrito anteriormente, podemos afirmar que o $\mathrm{Z}$ de altura final daquela criança ficaria entre $-3,72$ e $-0,36$ (previsão $\pm 2 \mathrm{DP}$ ) com $95 \%$ de confiança. Tal imprecisão da previsão inviabiliza a pretendida "tomada de decisão com base em evidências" pelos modelos preditivos, evidenciando, mais uma vez, a necessidade de melhora da acurácia do método.

\section{Ausência de estudos prospectivos}

É importante ressaltar que todos os estudos disponíveis até o momento sobre os resultados da terapia com GH em diferentes causas de baixa estatura e as tentativas de construção de modelos preditivos são fundamentados em dados retrospectivos/observacionais, o que impede qualquer conclusão definitiva.

Assim, embora a idéia de individualização da dose de GH, desde o início do tratamento a partir do uso de modelos preditivos, pareça uma estratégia adequada para se atingir o objetivo de proporcionar o máximo de benefício com o uso da menor dose cumulativa possível de $\mathrm{GH}$, esta hipótese ainda não foi testada em estudos prospectivos e controlados.

\section{PERSPECTIVAS: A FARMACOGENÔMICA DO TRATAMENTO COM GH}

A baixa capacidade preditiva e o amplo desvio-padrão da previsão feita com base nas variáveis conhecidas até o momento sugerem que importantes fatores determinantes de sensibilidade ao tratamento com GH ainda estejam por ser reconhecidos. Considerando-se que $75 \%$ a

Tabela 5. Poder preditivo e desvio-padrão para alguns dos principais modelos preditivos de resposta ao tratamento com GH em crianças com DGH.

\begin{tabular}{|c|c|c|c|}
\hline & Autor/revista/ano & Poder preditivo & Desvio-padrão \\
\hline \multirow[t]{3}{*}{ VC $1^{\circ}$ ano } & Blethen e cols., JCEM, 1993 (22) & $40 \%$ & $\star \star$ \\
\hline & Ranke e cols., JCEM, 1999 (3) & $61 \%$ & $1,46 \mathrm{~cm} / \mathrm{ano}$ \\
\hline & Cole e cols., Arch Dis Child, 2004 (23) & $42 \%$ & $0,29 \mathrm{DP}$ \\
\hline \multirow[t]{4}{*}{ Altura final } & Blethen e cols., JCEM, 1997 (7) & $47 \%$ & $\star \star *$ \\
\hline & Carel e cols., BMJ, 2002 (8) & $58 \%$ & ** \\
\hline & Reiter e cols., JCEM, 2006 (25) & $56 \%$ & ** \\
\hline & Ridder e cols., JCEM, 2007* (5) & $37 \%$ & $0,84 \mathrm{DP}$ \\
\hline
\end{tabular}

* Modelo incluindo apenas dados disponíveis no início do tratamento e aplicável para crianças pré-púberes do início ao final do primeiro ano de tratamento; *^ Dados não fornecidos nos artigos. 
90\% da altura de um indivíduo normal seja determinada geneticamente, e que a estatura-alvo foi um importante fator preditivo em diferentes modelos $(5,8,9,25)$, é bastante provável que fatores genéticos sejam fundamentais na determinação dessa resposta. Assim, tem sido crescente na literatura o interesse pelo estudo de variantes genéticas que possam influenciar a resposta ao tratamento com GH - a chamada "farmacogenômica do tratamento com hormônio de crescimento".

Os primeiros trabalhos nessa área tiveram como objeto de estudo o gene do receptor do GH (GHR), já que este é a primeira molécula-chave envolvida na mediação das ações do GH. Na população geral, existem duas isoformas do GHR: uma completa (GHRfl full-lenght) e uma apresentando deleção do éxon 3 (GHRd3), presente em cerca de $50 \%$ dos indivíduos normais. Embora as duas isoformas apresentem afinidades semelhantes pelo $\mathrm{GH}$, estudos funcionais demonstraram que células transientemente transfectadas com GHRd3 induzem maior transdução do sinal após tratamento com GH do que células transfectadas com o GHRfl. Em 2004, Santos e cols. (40) demonstraram que indivíduos apresentando pelo menos um alelo deletado para o exon 3 apresentavam VC no primeiro e no segundo ano de tratamento com GH superior à de indivíduos apresentando apenas o receptor full-lenght. Em 2006, nosso grupo demonstrou a influência positiva desse mesmo polimorfismo sobre a resposta ao tratamento com GH de crianças com DGH grave, tanto em relação à VC no primeiro ano quanto à altura final (41). Embora análises subseqüentes não tenham sido uniformes quanto a esta observação, estes estudos introduziram o importante conceito de que variações comuns em genes envolvidos no eixo GH - IGFl podem desempenhar papel na predição de resposta à terapia com $\mathrm{GH}(4 \mathrm{l})$.

É provável que nos próximos anos sejam identificados marcadores adicionais que permitam melhor caracterização da base genética envolvida com a resposta ao tratamento com GH e possivelmente melhora da acurácia de previsão.

\section{CONCLUSÕES}

A extensa experiência obtida até o momento com o uso de GH em doses fixas, com base no peso, torna evidente a necessidade de individualização das estratégias terapêuticas, a fim de que os objetivos do tratamento sejam alcançados de maneira mais homogênea entre os indivíduos. Hoje, sabe-se que diversos aspectos relacionados ao perfil biológico de cada indivíduo podem afetar a forma como este responde a dado regime terapêutico, e que por isso indivíduos com o mesmo diagnóstico e tratados segundo as mesmas recomendações apresentam respostas de crescimento tão variáveis. Fatores como a idade cronológica e o grau de déficit de altura observados no início do tratamento, a estatura-alvo e a dose de GH utilizada já estão bem estabelecidos como determinantes de resposta ao tratamento com GH. Além disso, sabe-se que determinada dose cumulativa de GH pode apresentar diferentes resultados finais, dependendo da forma como a dose é fracionada ao longo do tratamento.

A terapia individualizada fundamenta-se no ajuste da estratégia terapêutica conforme o perfil de sensibilidade de cada indivíduo, a fim de se obter o máximo de benefício com a mínima dose cumulativa possível. Idealmente, a terapia individualizada deve ser aplicada desde o momento da decisão quanto ao uso ou não do $\mathrm{GH}$ e com base em ajustes periódicos nas diferentes etapas do desenvolvimento da criança. Para que isso seja possível, no entanto, são necessárias ferramentas que permitam prever de maneira acurada e objetiva o potencial de resposta de cada indivíduo.

Nesse sentido, o desenvolvimento de modelos preditivos específicos para cada categoria diagnóstica e cada etapa do desenvolvimento constitui importante passo rumo à modernização e à otimização da terapia com GH. Algoritmos adequadamente precisos e que incluam a dose de $\mathrm{GH}$ como variável podem ser usados para prever a resposta de crescimento que será obtida com o uso de determinada dose de GH durante determinado período e, a partir disso, orientar o planejamento da estratégia terapêutica a ser utilizada durante o curso do tratamento. Além disso, permitem expectativas mais realistas quanto aos resultados, auxiliando, assim, de modo objetivo, a tomada de decisão quanto ao início do tratamento.

Com base nos conhecimentos obtidos até o momento, é possível prever cerca de $50 \%$ da variabilidade de resposta ao tratamento com $\mathrm{GH}$. Essa baixa capacidade preditiva indica que fatores determinantes genéticos e/ou ambientais ainda estejam por ser reconhecidos. Os resultados iniciais dos estudos de farmacogenômica do tratamento com $\mathrm{GH}$, indicando que um polimorfismo do GHR possa estar relacionado à capacidade de resposta ao tratamento com GH, sugerem que, no futuro, es- 
tudos de farmacogenética possam prover ferramentas adicionais para o refinamento dos modelos preditivos, permitindo, dessa forma, maior capacidade preditiva e, conseqüentemente, melhor precisão da previsão.

Embora estudos prospectivos sejam necessários para confirmar esta afirmação, é provável que a partir de instrumentos de previsão mais acurados possamos, finalmente, transferir a individualização do tratamento com GH do campo da teoria para a prática, assim, otimizando o custo-efetividade do tratamento e suplantando a tradicional abordagem terapêutica fundamentada no peso que vem sendo utilizada nos últimos 40 anos de experiência com GH.

\section{AGRADECIMENTOS}

Este trabalho obteve apoio da Fundação de Amparo à Pesquisa do Estado de São Paulo (Fapesp): Projeto Temático no 05/04726-0 e bolsa no 06/55763-5 para EFC; e do Conselho Nacional de Desenvolvimento Científico e Tecnológico (CNPq): 307951/06-5 para AALJ, 301246/95-5 para BBM e 300938/06-3 para IJPA.

\section{REFERÊNCIAS}

1. Cohen P, Bright GM, Rogol AD, Kappelgaard AM, Rosenfeld RG. Effects of dose and gender on the growth and growth factor response to $\mathrm{GH}$ in $\mathrm{GH}$-deficient children: implications for efficacy and safety. J Clin Endocrinol Metab. 2002;87:90-8.

2. Geffner ME, Dunger DB. Future directions: growth prediction models. Horm Res. 2007;68 Suppl 5:51-6.

3. Ranke MB. Prediction of response to $\mathrm{GH}$ : does it help to individualize therapy? Curr Opin Endocrinol Diabetes. 1999;6:93-9.

4. Ridder MA, Stijnen T, Hokken-Koelega AC. Validation and calibration of the Kabi Pharmacia International Growth Study prediction model for children with idiopathic growth hormone deficiency. J Clin Endocrinol Metab. 2003;88:1223-27.

5. Ridder MA, Stijnen T, Hokken-Koelega AC. Prediction of adult height in growth-hormone-treated children with growth hormone deficiency. J Clin Endocrinol Metab. 2007;92:925-31.

6. August GP, Julius JR, Blethen SL. Adult height in children with growth hormone deficiency who are treated with biosynthetic growth hormone: the National Cooperative Growth Study experience. Pediatrics. 1998;102:512-6.

7. Blethen SL, Baptista J, Kuntze J, Foley T, LaFranchi S, Johanson $A$. Adult height in growth hormone $(\mathrm{GH})$-deficient children treated with biosynthetic GH. The Genentech Growth Study Group. J Clin Endocrinol Metab. 1997;82:418-20.

8. Carel JC, Ecosse E, Nicolino M, Tauber M, Leger J, Cabrol S, et al. Adult height after long term treatment with recombinant growth hormone for idiopathic isolated growth hormone deficiency: observational follow up study of the French population based registry. BMJ. 2002;325:70.
9. Cutfield W, Lindberg A, Albertsson-Wikland K, Chatelain P, Ranke MB, Wilton P. Final height in idiopathic growth hormone deficiency: the KIGS experience. KIGS International Board. Acta Paediatr Suppl. 1999;88:72-5.

10. Ranke $M B$, Lindberg $A$, Chatelain $P$, Wilton $P$, Cutfield $W, A I-$ bertsson-Wikland $K$, et al. Derivation and validation of a mathematical model for predicting the response to exogenous recombinant human growth hormone $(\mathrm{GH})$ in prepubertal children with idiopathic GH deficiency. KIGS International Board. Kabi Pharmacia International Growth Study. J Clin Endocrinol Metab. 1999;84:1174-83.

11. Ranke MB, Lindberg $A$, Chatelain $P$, Wilton $P$, Cutfield $W, A I-$ bertsson-Wikland $\mathrm{K}$, et al. Predicting the response to recombinant human growth hormone in Turner syndrome: KIGS models. KIGS International Board. Kabi International Growth Study. Acta Paediatr Suppl. 1999;88:122-5.

12. Ranke $M B$, Lindberg $A$, Chatelain $P$, Wilton $P$, Cutfield $W, A I-$ bertsson-Wikland K, et al. Prediction of long-term response to recombinant human growth hormone in Turner syndrome: development and validation of mathematical models. KIGS International Board. Kabi International Growth Study. J Clin Endocrinol Metab. 2000;85:4212-8.

13. Ranke MB, Lindberg A, Ferrandez Longas A, Darendeliler F, Albertsson-Wikland K, Dunger D, et al. Major determinants of height development in Turner syndrome (TS) patients treated with GH: analysis of 987 patients from KIGS. Pediatr Res. 2007;61:105-10.

14. Ranke MB, Lindberg A, Price DA, Darendeliler F, AlbertssonWikland K, Wilton $P$, et al. Age at growth hormone therapy start and first-year responsiveness to growth hormone are major determinants of height outcome in idiopathic short stature. Horm Res. 2007;68:53-62.

15. Soriano-Guillen L, Coste J, Ecosse E, Leger J, Tauber M, Cabrol $\mathrm{S}$, et al. Adult height and pubertal growth in Turner syndrome after treatment with recombinant growth hormone. J Clin Endocrinol Metab. 2005;90:5197-204.

16. Wikland KA, Kristrom B, Rosberg S, Svensson B, Nierop AF. Validated multivariate models predicting the growth response to $\mathrm{GH}$ treatment in individual short children with a broad range in GH secretion capacities. Pediatr Res. 2000;48:475-84.

17. Wit JM, Kamp GA, Rikken B. Spontaneous growth and response to growth hormone treatment in children with growth hormone deficiency and idiopathic short stature. Pediatr Res. 1996;39:295-302.

18. Ranke MB, Cutfield WS, Lindberg A, Cowell CT, AlbertssonWikland K, Reiter EO, et al. A growth prediction model for short children born small for gestational age. J Pediatr Endocrinol Metab. 2002;15 Suppl 5:1273.

19. Ranke MB, Lindberg A, Cowell CT, Wikland KA, Reiter EO, Wilton $\mathrm{P}$, et al. Prediction of response to growth hormone treatment in short children born small for gestational age: analysis of data from KIGS (Pharmacia International Growth Database). J Clin Endocrinol Metab. 2003;88:125-31.

20. Ranke MB, Lindberg A, Albertsson-Wikland $K$, Wilton $P$, Price DA, Reiter EO. Increased response, but lower responsiveness, to growth hormone $(\mathrm{GH})$ in very young children (aged 0-3 years) with idiopathic GH deficiency: analysis of data from KIGS. J Clin Endocrinol Metab. 2005;90:1966-71.

21. Ranke MB, Lindberg A, Martin DD, Bakker B, Wilton P, Albertsson-Wikland $\mathrm{K}$, et al. The mathematical model for total pubertal growth in idiopathic growth hormone (GH) deficiency suggests a moderate role of $\mathrm{GH}$ dose. J Clin Endocrinol Metab. 2003;88:4748-53. 
22. Blethen SL, Compton P, Lippe BM, Rosenfeld RG, August GP, Johanson $A$. Factors predicting the response to growth hormone $(\mathrm{GH})$ therapy in prepubertal children with $\mathrm{GH}$ deficiency. J Clin Endocrinol Metab. 1993;76:574-9.

23. Cole TJ, Hindmarsh PC, Dunger DB. Growth hormone (GH) provocation tests and the response to $\mathrm{GH}$ treatment in $\mathrm{GH}$ deficiency. Arch Dis Child. 2004;89:1024-7.

24. Schonau E, Westermann F, Rauch F, Stabrey A, Wassmer G, Keller $E$, et al. A new and accurate prediction model for growth response to growth hormone treatment in children with growth hormone deficiency. Eur J Endocrinol. 2001;144:13-20.

25. Reiter EO, Price DA, Wilton P, Albertsson-Wikland K, Ranke $M B$. Effect of growth hormone (GH) treatment on the near-final height of 1258 patients with idiopathic $\mathrm{GH}$ deficiency: analysis of a large international database. J Clin Endocrinol Metab. 2006;91:2047-54.

26. Hibi I, Tanaka T. Final height of patients with idiopathic growth hormone deficiency after long-term growth hormone treatment. Committee for Treatment of Growth Hormone Deficient Children, Growth Science Foundation, Japan. Acta Endocrinol (Copenh). 1989;120:409-15.

27. Wit JM, Faber JA, van den Brande JL. Growth response to human growth hormone treatment in children with partial and total growth hormone deficiency. Acta Paediatr Scand. 1986;75:767-73.

28. Frasier SD, Costin G, Lippe BM, Aceto T Jr., Bunger PF. A doseresponse curve for human growth hormone. J Clin Endocrinol Metab. 1981;53:1213-7.

29. Preece MA, Tanner JM, Whitehouse RH, Cameron N. Dose dependence of growth response to human growth hormone in growth hormone deficiency. J Clin Endocrinol Metab. 1976;42:477-83.

30. Birnbacher R, Riedl S, Frisch H. Long-term treatment in children with hypopituitarism: pubertal development and final height. Horm Res. 1998;49:80-5.

31. Albertsson-Wikland $\mathrm{K}$. The effect of human growth hormone injection frequency on linear growth rate. Acta Paediatr Scand. 1987;337:110-6.

32. Frisch $\mathrm{H}$, Birnbacher R. Final height and pubertal development in children with growth hormone deficiency after long-term treatment. Horm Res. 1995;43:132-4.

33. Bright GM, Julius JR, Lima J, Blethen SL. Growth hormone stimulation test results as predictors of recombinant human growth hormone treatment outcomes: preliminary analysis of the national cooperative growth study database. Pediatrics. 1999;104:1028-31.

34. Radetti G, Buzi F, Cassar W, Paganini C, Stacul E, Maghnie M. Growth hormone secretory pattern and response to treatment in children with short stature followed to adult height. Clin Endocrinol (Oxf). 2003;59:27-33.

35. Guyda HJ. Four decades of growth hormone therapy for short children: what have we achieved? J Clin Endocrinol Metab. 1999;84:4307-16.

36. Rosenbloom AL. A mathematical model for predicting growth response to growth hormone replacement therapy--a useful clinical tool or an intellectual exercise? J Clin Endocrinol Metab. 1999;84:1172-3.

37. De Boer $\mathrm{H}$, van der Veen EA. Why retest young adults with childhood-onset growth hormone deficiency? J Clin Endocrinol Metab. 1997;82:2032-6.

38. Longobardi S, Merola B, Pivonello R, Di Rella F, Di Somma C, Colao $A$, et al. Reevaluation of growth hormone $(\mathrm{GH})$ secretion in 69 adults diagnosed as $\mathrm{GH}$-deficient patients during childhood. J Clin Endocrinol Metab. 1996;81:1244-7.

39. Tillmann V, Buckler JM, Kibirige MS, Price DA, Shalet SM, Wales JK, et al. Biochemical tests in the diagnosis of childhood growth hormone deficiency. J Clin Endocrinol Metab. 1997;82:531-5.

40. Santos C, Essioux L, Teinturier C, Tauber M, Goffin V, Bougneres $\mathrm{P}$. A common polymorphism of the growth hormone receptor is associated with increased responsiveness to growth hormone. Nat Genet. 2004;36:720-4.

41. Jorge AA, Marchisotti FG, Montenegro LR, Carvalho LR, Mendonça BB, Arnhold IJ. Growth hormone (GH) pharmacogenetics: influence of $\mathrm{GH}$ receptor exon 3 retention or deletion on first-year growth response and final height in patients with severe GH deficiency. J Clin Endocrinol Metab. 2006;91:1076-80.

\section{Endereço para correspondência:}

Ivo J. P. Arnhold

Av. Dr. Enéas de Carvalho Aguiar, 155, PAMB, $2^{\circ}$ andar, bloco 6 05403-900 São Paulo, SP

E-mail: iarnhold@usp.br. 


\title{
The -202 A Allele of Insulin-Like Growth Factor Binding Protein-3 (IGFBP3) Promoter Polymorphism Is Associated with Higher IGFBP-3 Serum Levels and Better Growth Response to Growth Hormone Treatment in Patients with Severe Growth Hormone Deficiency
}

\author{
Everlayny Fiorot Costalonga, Sonir R. Antonini, Gil Guerra-Junior, \\ Berenice Bilharinho Mendonca, Ivo J. P. Arnhold, and Alexander A. L. Jorge \\ Unidade de Endocrinologia do Desenvolvimento (E.F.C., B.B.M., I.J.P.A., A.A.L.J.), Laboratorio de Hormonios e Genetica \\ Molecular LIM/42, Faculdade de Medicina da Universidade de Sao Paulo, 05403-900 Sao Paulo, Brazil; Departamento de \\ Pediatria (S.R.A.), Faculdade de Medicina de Ribeirao Preto, Universidade de Sao Paulo, 14049-900 Sao Paulo, Brazil; and \\ Departamento de Pediatria (G.G.J.), Faculdade de Medicina de Campinas, 13083-100 Sao Paulo, Brazil
}

\begin{abstract}
Context: Genetic factors that influence the response to recombinant human GH (rhGH) therapy remain mostly unknown. To date, only the $\mathrm{GH}$ receptor gene has been investigated.

Objective: The aim of the study was to assess the influence of a polymorphism in the IGF-binding protein-3 (IGFBP-3) promoter region ( $-202 \mathrm{~A} / \mathrm{C}$ ) on circulating IGFBP-3 levels and growth response to rhGH therapy in children with GH deficiency (GHD).

Design and Patients: -202 A/C IGFBP3 genotyping (rs2854744) was correlated with data of 71 children with severe GHD who remained prepubertal during the first year of rhGH treatment.

Main Outcome Measures: We measured IGFBP-3 levels and first year growth velocity (GV) during rhGH treatment.

Results: Clinical and laboratory data at the start of treatment were indistinguishable among patients with different -202 A/C IGFBP3 genotypes. Despite similar rhGH doses, patients homozygous for the A allele presented higher IGFBP-3 sD score levels and higher mean GV in the first year of rhGH treatment than patients with $A C$ or CC genotypes (first year GV, AA $=13.0 \pm 2.1 \mathrm{~cm} / \mathrm{yr}, A C=11.4 \pm$ $2.5 \mathrm{~cm} / \mathrm{yr}$, and $C C=10.8 \pm 1.9 \mathrm{~cm} / \mathrm{yr} ; P=0.016$ ). Multiple linear regression analyses demonstrated that the influence of -202 A/C IGFBP3 genotype on IGFBP-3 levels and GV during the first year of rhGH treatment was independent of other variables.
\end{abstract}

Conclusion: The -202 A allele of IGFBP3 promoter region is associated with increased IGFBP-3 levels and GV during rhGH treatment in prepubertal GHD children. (J Clin Endocrinol Metab 94: 588-595, 2009)

G H replacement is a standard therapy for children with short stature due to GH deficiency (GHD). The usual treatment is carried out with empirical and fixed doses of recombinant human $\mathrm{GH}$ (rhGH) adjusted uniquely for body weight or surface (1). Although it is expected that rhGH replacement completely

ISSN Print 0021-972X ISSN Online 1945-7197

Printed in U.S.A.

Copyright (C) 2009 by The Endocrine Society

doi: 10.1210/jc.2008-1608 Received July 25, 2008. Accepted October 29, 2008. First Published Online November 4, 2008 resolves growth impairment in children with severe GHD, these patients exhibit considerable interindividual variability regarding growth responses to rhGH.

Some of the clinical factors that influence growth response to rhGH have already been identified, such as maximum GH peak

Abbreviations: BMI, Body mass index; CLIA, chemiluminescence assay; CPHD, combined pituitary hormone deficiency; GHD, GH deficiency; IGFBP-3, IGF-binding protein-3; IGHD, isolated GHD; IFMA, immunofluorometric assay; IRMA, immunoradiometric assay; rhGH, recombinant human GH; SDS, SD Score. 
in provocative tests (2-5), age and height SD scores (SDS) at the beginning of treatment $(2-4,6)$, target height $(3-5)$, and duration of treatment $(3,5,6)$. However, these variables explain only 40 to $61 \%$ of rhGH responsiveness at the first year of therapy and 37 to $58 \%$ of variability at final height, implying that further parameters may be missing from current prediction models.

Until recently, genetic factors that influence growth response to rhGH were indirectly taken into account by including parental heights in the growth prediction models (3-5). To date, only the $\mathrm{GH}$ receptor gene has been investigated in rhGH pharmacogenetic studies (7-9). Despite the heterogeneity of early results, these studies introduced the important concept that common variations in GH/IGF-I axis genes may play a role in predicting response to rhGH therapy.

GH promotes growth mainly by IGF-I, which acts by endocrine and paracrine mechanisms. IGF-I transport in serum is mediated mostly by IGF-binding protein-3 (IGFBP-3) and acid labile subunit. Besides being the major carrying protein for IGF-I in the circulation, IGFBP-3 can act as a modulator of IGF-I bioactivity and has IGF-I-independent actions on growth regulation at the tissue level $(10-14)$. Twin studies indicated that about $60 \%$ of the interindividual variability in circulating levels of IGFBP-3 is genetically determined (15). The IGFBP3 gene is highly conserved among species and is present as a single copy on chromosome 7p14-p12. In 2001, Deal et al. (16) identified several single-nucleotide polymorphisms in the promoter region of IGFBP3. The most relevant single-nucleotide polymorphism (rs2854744) was an A to C nucleotide change located 202 bp upstream to the transcription start site, near elements believed to control basal promoter activity of IGFBP3. Genotype at this locus was highly correlated to circulating levels of IGFBP-3 in healthy adults. Mean IGFBP-3 levels were highest in individuals with the AA genotype and declined significantly in a stepwise manner in the presence of one or two copies of the $\mathrm{C}$ allele. Further studies confirmed this genotype-phenotype association (17-23). Additionally, in vitro studies documented significantly higher promoter activity of the A allele in comparison to the $\mathrm{C}$ allele (16), supporting the functional importance of $-202 \mathrm{~A} / \mathrm{C}$ polymorphism.

Until now, there were no data on the effect of this polymorphism on the IGFBP-3 serum levels and growth response to $\mathrm{rhGH}$ treatment in children with GHD. Therefore, the aim of our study was to evaluate the influence of the $-202 \mathrm{~A} / \mathrm{C}$ IGFBP 3 promoter polymorphism on the serum levels of IGFBP-3 and growth response to rhGH therapy in children with severe GHD.

\section{Subjects and Methods}

\section{Subjects}

Seventy-one severe GHD patients who were treated exclusively with rhGH on a daily schedule and who remained prepubertal throughout the first year of therapy were selected for evaluation of first year growth velocity and IGFBP-3 serum levels. Among these patients, 36 have already reached adult height after $8 \pm 3$ yr of rhGH treatment and were also analyzed regarding final height growth outcomes. GHD diagnosis was based on clinical and auxological parameters as well as the failure of GH response on at least two provocative tests. Patients with central nervous system tumors, meningoencephalocele, or previous radiation therapy were not included.

Magnetic resonance imaging of the hypothalamic-pituitary region was performed in all patients. According to the basal levels and hormonal response to the combined test (insulin $+\mathrm{TRH}+\mathrm{GnRH}$ ), patients were classified as isolated GHD (IGHD) or combined pituitary hormone deficiency (CPHD). Patients with CPHD were on regular replacement therapy for the other hormonal deficiencies.

The study protocol was approved by the Hospital Ethics Committee, and informed consent was obtained from all patients or their parents before initiating the molecular studies.

\section{Study protocol}

$\mathrm{rhGH}$ was administered sc at a mean dose of $32 \mu \mathrm{g} / \mathrm{kg} \cdot \mathrm{d}(0.1 \mathrm{IU} /$ $\mathrm{kg} \cdot \mathrm{d}$ ), which was adjusted according to changes in weight at each visit. All children were evaluated at baseline and every 3-4 months during rhGH treatment. First year growth velocity was determined after an observation period of at least 11 months. Among the 36 GHD patients who completed growth, the adult height was measured, on average, 1.4 yr after rhGH withdrawal. Evaluations were performed at the same period of day and included measurements of weight (measured with a digital scale) and standing height (measured with a stadiometer). Height and body mass index (BMI) were expressed as SDS (24, 25). Target height was calculated [(father's height + mother's height $+13 \mathrm{~cm}$ for boys or $-13 \mathrm{~cm}$ for girls)/2] and expressed as SDS. Left hand and wrist $\mathrm{x}$-rays for bone age determination were assessed based on the method of Greulich and Pyle (26). IGF-I and IGFBP-3 levels were measured both before and during therapy.

\section{Hormone assays}

$\mathrm{GH}$ was initially measured by immunoradiometric assay (IRMA) (61\% of the patients) and subsequently by immunofluorometric assay (IFMA) (AutoDELFIA, Wallac, Turku, Finland) method with monoclonal antibodies (39\% of the patients). Cutoff levels used for GHD diagnosis were peak GH levels no greater than $5.0 \mu \mathrm{g} /$ liter (IRMA) or no greater than $3.3 \mu \mathrm{g} /$ liter (IFMA).

IGF-I levels were obtained at the start of treatment and near the end of the first year of rhGH therapy in 65 and $77 \%$ of patients, respectively. IGF-I was measured by RIA after ethanol extraction (Diagnostic Systems Laboratories, Webster, TX) (91\% of patients) or by chemiluminescence assays (CLIA) (IMMULITE; Diagnostic Products Corp., Los Angeles, CA) ( $9 \%$ of patients). IGFBP-3 levels were obtained at the start of treatment and near the end of the first year of rhGH therapy in 51 and $72 \%$ of patients, respectively. IGFBP-3 was measured by IRMA (Diagnostic Systems Laboratories, 90\%) or CLIA (IMMULITE, 10\%). IGF-I and IGFBP-3 levels were expressed as SDS for age and sex according to reference values provided by the respective assay kits.

\section{Molecular studies}

Genomic DNA was isolated from peripheral blood leukocytes by standard methods from all patients. A 376-bp fragment encompassing the $-202 \mathrm{~A} / \mathrm{C}$ polymorphic site at the promoter region of IGFBP3 gene was amplified using specific primers, and PCR products were digested with FspI enzyme (New England Biolabs, Beverly, MA). In the presence of the C allele, the 376-bp PCR fragment is digested into 260-bp and 116-bp fragments, whereas in the presence of the A allele, the restriction site is absent. Primer sequences, amplification protocols, and digestion protocols will be sent upon request.

The validity of the PCR-restriction-fragments length polymorphism analysis was verified by direct sequencing of each genotype using the BigDye FN Sequencing kit (PE Applied Biosystems, Foster City, CA). For quality control, we regenotyped approximately $10 \%$ of random samples. The agreement of the genotypes determined for the blinded quality control samples was $100 \%$. 


\section{Statistical analysis}

Qualitative variables are listed as frequencies and percentages, whereas quantitative variables are shown as mean \pm SD. Patients were compared by genotype relative to clinical and laboratory characteristics. The short-term response to rhGH was evaluated by growth velocity in the first year of treatment. The long-term response to $\mathrm{rhGH}$ was assessed by adult height SDS and adult height SDS minus target height SDS. IGF-I and IGFBP-3 levels were evaluated as SDS for age and sex both before and during treatment.

Genotype-group comparisons were performed according to two genetic models: a codominant model, in which the three genotypes were analyzed separately (AA vs. AC vs. CC), and a recessive model, in which patients homozygous for the A allele (AA group) were compared with patients presenting at least one copy of the $\mathrm{C}$ allele (AC + CC group). The recessive model was the most frequent approach adopted in previous studies, which evaluated the effects of $-202 \mathrm{~A} / \mathrm{C}$ IGFBP3 polymorphism $(16,17,20-22)$. ANOVA followed by Tukey test was used for comparisons according to the codominant model (AA vs. AC vs. CC), whereas the $t$ test was used for comparisons according to the recessive model (AA vs. AC + CC). Numerical variables that did not demonstrate parametric distribution ( $\mathrm{GH}$ peak levels and mean rhGH doses) were analyzed by Kruskal-Wallis one-way ANOVA on ranks or Mann-Whitney rank sum test. Nominal variables were compared by $\chi^{2}$ or Fisher exact test, as appropriate.

To assess whether genetic variants had independent prognostic significance for outcome, we performed single followed by multiple regression analyses adjusting for the established influential factors. A $P$ value $<0.05$ was considered statistically significant. All statistical analyses were performed with SigmaStat for Windows (version 2.03; SPSS, Inc., San Rafael, CA).

\section{Results}

\section{Patient's phenotype at the start of therapy}

Seventy-one prepubertal GHD children ( 48 boys and 23 girls) were evaluated. At the start of treatment, they presented a chronological age of $8.6 \pm 4.1 \mathrm{yr}$, with marked bone age delay ( $4.3 \pm$ $2.7 \mathrm{yr}$ ) and short stature (height SDS, $-4.3 \pm 1.4$ ). Severe GHD was demonstrated by extremely low GH peak levels, obtained at two different stimulation tests (mean GH peak, $0.9 \pm 0.9 \mu \mathrm{g}$ / liter; range, $<0.1$ to $3.3 \mu \mathrm{g} /$ liter). No difference in mean GH peak was observed between patients diagnosed by IFMA or IRMA $\mathrm{GH}$ assays. Ninety-two percent of patients had either a defined genetic etiology for GHD (12 patients) or an anatomic abnormality of the pituitary gland on magnetic resonance imaging (ectopic posterior lobe in 45 patients and interrupted stalk in 18). Twenty-nine patients presented IGHD, and 42 had CPHD. Among the latter, central hypothyroidism was found in $77 \%$, ACTH deficiency in $45 \%$, and diabetes insipidus in $12 \%$; in $53 \%$, central hypogonadism was diagnosed during follow-up. Patients with IGHD and CPHD presented similar growth responses during rhGH treatment and, therefore, were analyzed together. Pretreatment growth velocity was not available because, due to the severity of short stature in the majority of patients, treatment was started after prompt GHD diagnosis.

\section{Clinical correlations with -202 A/C IGFBP3 genotyping}

The distribution of patients among the different -202 IGFBP3 genotypes was $21 \% \mathrm{AA}, 54 \% \mathrm{AC}$, and $25 \% \mathrm{CC}$. The genotype frequencies conformed to the Hardy-Weinberg equilibrium test. There were no significant differences between genotype groups regarding clinical features at the start of treatment, GH peak at stimulation tests, and mean rhGH dose during treatment (Tables 1 and 2).

\section{IGF-I and IGFBP-3 SDS levels}

Before the start of treatment, there was a tendency to lower IGFBP-3 levels adjusted for age and sex in patients presenting one or two copies of the -202 C IGFBP3 allele, but this difference was not significant. During rhGH treatment, patients homozygous for the A allele presented significantly higher IGFBP-3 levels than $C$ allele carriers in codominant $(P=0.002)$ and recessive models $(P<0.001)$ (Table 1 and Fig. 1$)$. Additionally, patients homozygous for the A allele presented significant higher incre-

TABLE 1. Clinical and auxological characteristics of 71 children with GHD grouped according to -202 A/C IGFBP3 genotype

\begin{tabular}{|c|c|c|c|c|c|c|}
\hline & \multicolumn{4}{|c|}{-202 A/C IGFBP3 genotype } & \multicolumn{2}{|c|}{$P$} \\
\hline & AA & AC & $\mathrm{CC}$ & $\mathrm{AC}+\mathrm{CC}$ & $A A$ vs. $A C$ vs. $C C$ & $A A$ vs. $A C+C C$ \\
\hline$n$ & 15 & 38 & 18 & 56 & & \\
\hline Gender (males:females) & $11: 4$ & $26: 12$ & $11: 7$ & $37: 19$ & ns & ns \\
\hline IGHD:CPHD & $14: 11$ & $17: 21$ & $8: 10$ & $25: 31$ & ns & ns \\
\hline Target height SDS & $-1.1 \pm 0.9$ & $-0.8 \pm 0.8$ & $-1.0 \pm 0.8$ & $-0.9 \pm 0.8$ & ns & ns \\
\hline Highest GH peak ( $\mu \mathrm{g} /$ liter) & $0.5 \pm 0.7$ & $0.9 \pm 0.8$ & $1.0 \pm 1.0$ & $1.0 \pm 0.9$ & ns & ns \\
\hline Chronological age (yr) & $9.6 \pm 4.8$ & $8.5 \pm 4.3$ & $8.2 \pm 3.1$ & $8.4 \pm 3.9$ & ns & ns \\
\hline Bone age delay (yr) & $5.2 \pm 3.1$ & $4.2 \pm 2.8$ & $3.8 \pm 2.1$ & $4.1 \pm 2.6$ & ns & ns \\
\hline Basal height SDS & $-4.2 \pm 1.2$ & $-4.5 \pm 1.6$ & $-3.7 \pm 0.7$ & $-4.3 \pm 1.4$ & ns & ns \\
\hline Basal BMI SDS & $-0.6 \pm 1.3$ & $-0.5 \pm 1.3$ & $0.0 \pm 1.3$ & $-0.3 \pm 1.3$ & ns & ns \\
\hline Mean rhGH dose $(\mu \mathrm{g} / \mathrm{kg} \cdot \mathrm{d})$ & $29 \pm 9$ & $32 \pm 10$ & $29 \pm 9$ & $32 \pm 8$ & ns & ns \\
\hline IGFBP-3 SDS pretreatment & $-2.3 \pm 0.9$ & $-2.6 \pm 1.3$ & $-2.9 \pm 0.5$ & $-2.7 \pm 1.1$ & ns & ns \\
\hline IGFBP-3 SDS during treatment & $0.4 \pm 1.9$ & $-1.0 \pm 1.0$ & $-1.5 \pm 1.4$ & $-1.2 \pm 1.2$ & $0.002^{a}$ & $<0.001$ \\
\hline IGF-I SDS pretreatment & $-1.8 \pm 1.4$ & $-2.4 \pm 1.6$ & $-2.3 \pm 1.5$ & $-2.3 \pm 1.5$ & ns & ns \\
\hline IGF-I SDS during treatment & $-0.5 \pm 1.6$ & $-0.1 \pm 1.9$ & $-0.8 \pm 0.9$ & $-0.3 \pm 1.7$ & ns & ns \\
\hline First year growth velocity (cm/yr) & $13.1 \pm 2.1$ & $11.4 \pm 2.5$ & $10.8 \pm 1.9$ & $11.2 \pm 2.3$ & $0.016^{b}$ & 0.007 \\
\hline First year growth velocity SDS & $5.1 \pm 3.0$ & $3.3 \pm 2.9$ & $3.2 \pm 2.9$ & $3.2 \pm 2.9$ & ns & 0.037 \\
\hline
\end{tabular}

ns, Not significant.

a Tukey test: AA vs. AC, $P=0.008 ; A C$ vs. $C C, P=0.63 ; A A$ vs. $C C, P=0.004$

${ }^{b}$ Tukey test: $A A$ vs. AC, $P=0.05 ; A C$ vs. $C C, P=0.58 ; A A$ vs. $C C, P=0.015$ 
Apêndice 2

TABLE 2. Clinical and auxological characteristics of 36 children with severe GHD who reached adult height after long-term treatment with $\mathrm{rhGH}$, grouped according to $-202 \mathrm{~A} / \mathrm{C}$ IGFBP3 genotype

\begin{tabular}{|c|c|c|c|c|}
\hline & \multicolumn{4}{|c|}{-202 A/C IGFBP3 genotype } \\
\hline & AA & $A C$ & $\mathrm{CC}$ & $A C+C C$ \\
\hline $\mathrm{n}$ & 9 & 19 & 8 & 27 \\
\hline Gender (males:females) & $7: 2$ & $14: 5$ & $5: 3$ & $19: 8$ \\
\hline IGHD:CPHD & $2: 7$ & $9: 10$ & $3: 5$ & $12: 15$ \\
\hline Target height SDS & $-1.1 \pm 0.9$ & $-0.9 \pm 0.7$ & $-0.9 \pm 0.8$ & $-0.9 \pm 0.7$ \\
\hline Highest GH peak ( $\mu \mathrm{g} / \mathrm{liter})$ & $0.6 \pm 0.7$ & $1.1 \pm 0.9$ & $1.1 \pm 1.0$ & $1.1 \pm 0.9$ \\
\hline Chronological age (yr) & $10.7 \pm 4.2$ & $10.5 \pm 3.9$ & $9.2 \pm 2.4$ & $10.1 \pm 3.5$ \\
\hline Bone age delay (yr) & $5.8 \pm 3.0$ & $5.4 \pm 3.0$ & $4.1 \pm 2.0$ & $5.0 \pm 2.9$ \\
\hline Basal height SDS & $-4.3 \pm 1.1$ & $-5.0 \pm 1.8$ & $-3.8 \pm 1.1$ & $-4.6 \pm 1.7$ \\
\hline Spontaneous:induced puberty & $3: 6$ & $11: 8$ & $4: 4$ & $15: 12$ \\
\hline Age at start puberty (yr) & $14.9 \pm 2.9$ & $15.2 \pm 3.4$ & $14.9 \pm 3.7$ & $15.1 \pm 3.4$ \\
\hline Treatment duration (yr) & $8.3 \pm 2.2$ & $8.4 \pm 3.3$ & $9.9 \pm 3.5$ & $8.8 \pm 3.3$ \\
\hline Mean rhGH dose $(\mu \mathrm{g} / \mathrm{kg} \cdot \mathrm{d})$ & $38 \pm 5$ & $36 \pm 8$ & $32 \pm 10$ & $35 \pm 9$ \\
\hline Final height SDS & $-0.6 \pm 0.6$ & $-1.1 \pm 1.1$ & $-1.2 \pm 1.6$ & $-1.1 \pm 1.2$ \\
\hline Final height SDS-target height & $0.5 \pm 0.7$ & $-0.1 \pm 1.1$ & $-0.4 \pm 2.2$ & $-0.2 \pm 1.5$ \\
\hline
\end{tabular}

For all variables, comparison of genotypes (AA vs. AC vs. CC and AA vs. AC + CC) were not significant.

ment in IGFBP-3 SDS levels after treatment than patients presenting at least one $\mathrm{C}$ allele $(\Delta \mathrm{IGFBP}-3 \mathrm{SDS}, \mathrm{AA}=2.8 \pm 1.4 v \mathrm{~s}$. $\mathrm{AC}$ or $\mathrm{CC}=1.6 \pm 1.3 ; P=0.02)$.

The observed relationship between IGFBP- 3 serum levels during rhGH treatment and $-202 \mathrm{~A} / \mathrm{C}$ IGFBP3 genotype was independent of many other clinical variables, such as age, sex, BMI, and rhGH doses, as demonstrated by multiple regression analyses. Alone, IGFBP3 polymorphism accounted for 19\% of IGFBP-3 serum level variation $(P<0.001)$ and, together with age $(P<0.001)$ and gender $(P=0.003)$, explained $54 \%$ of observed variation. Data analysis excluding IGF-I and IGFBP-3 measured by CLIA (about $10 \%$ of measurements) presented similar results (data not shown). There was no relation between -202 A/C IGFBP3 genotype and IGF-I levels before the start of treatment, as well as during treatment (Table 1).

\section{First year growth velocity}

Mean growth velocity in the first year of rhGH treatment was higher in patients with the AA genotype and declined significantly in a stepwise manner in the presence of one or two copies of the $\mathrm{C}$ allele (first year growth velocity, $\mathrm{AA}=13.0 \pm 2.1 \mathrm{~cm} / \mathrm{yr}$, $\mathrm{AC}=11.4 \pm 2.5 \mathrm{~cm} / \mathrm{yr}$, and $\mathrm{CC}=10.8 \pm 1.9 \mathrm{~cm} / \mathrm{yr} ; P=0.016)$ (Table 1 and Fig. 2). As a group, patients with at least one $\mathrm{C}$ allele presented a mean growth velocity $1.9 \mathrm{~cm} / \mathrm{yr}$ lower than that of patients homozygous for the A allele $(95 \%$ confidence interval for difference of means, 0.5 to $3.2 \mathrm{~cm} / \mathrm{yr} ; P=0.007)$. Similar results were observed when growth velocities were analyzed as SDS adjusted for sex and age (Table 1).

Additionally, single followed by multiple linear regression analyses demonstrated that the influence of this polymorphism on growth velocity was independent of other variables. Alone,

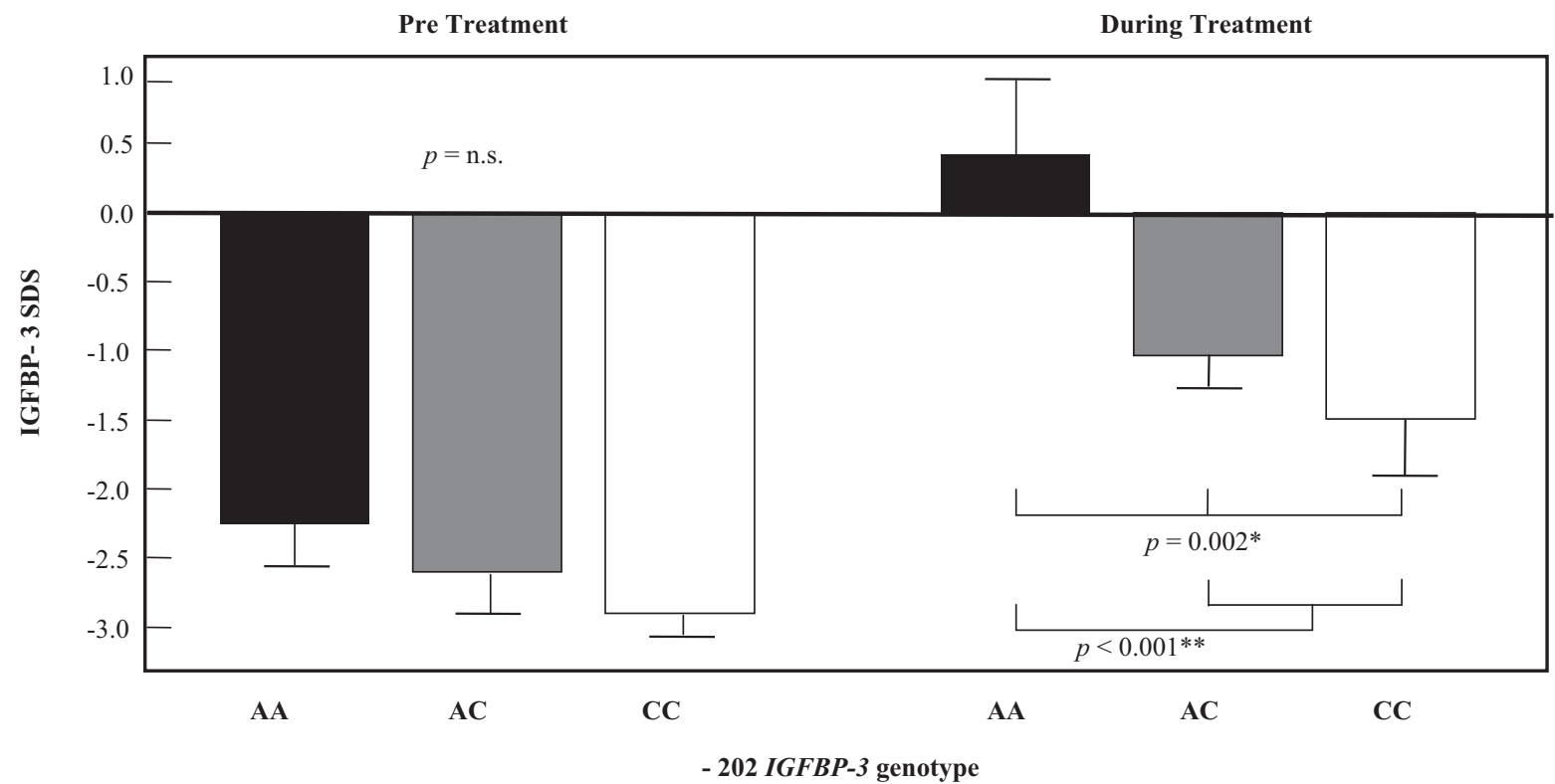

Fig. 1. Influence of the -202 A/C IGFBP3 genotype on IGFBP-3 SDS levels in 71 prepubertal children with severe GHD before treatment and during rhGH treatment (mean \pm SEM). ${ }^{*}, A A$ vs. AC vs. CC; ${ }^{* *}, A A$ vs. AC + CC. 


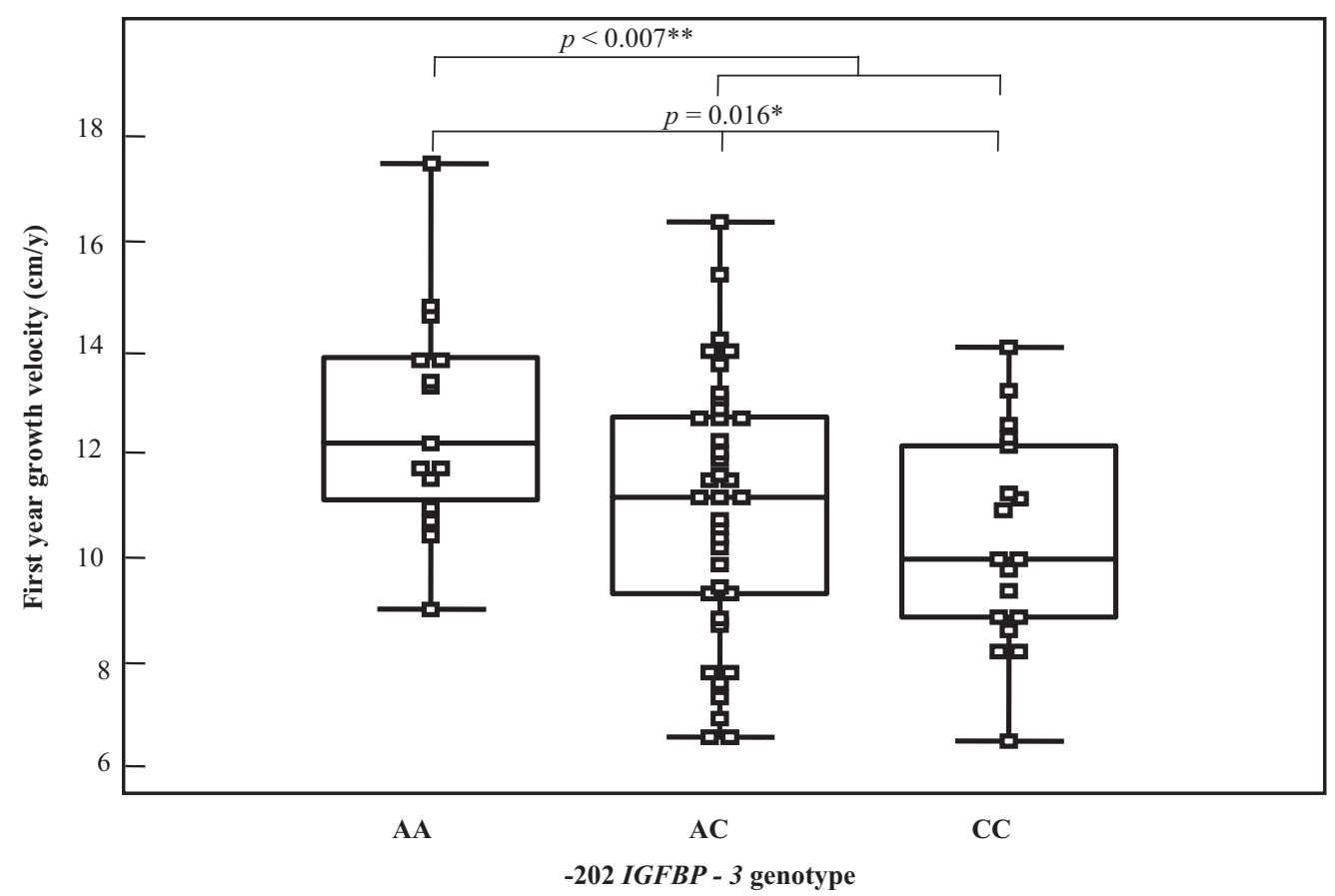

Fig. 2. Individual growth velocities of 71 prepubertal children with GHD during the first year of rhGH treatment, according to -202 A/C IGFBP3 genotype. *, AA vs. $A C$ vs. $C C ;{ }^{* *}, A A$ vs. $A C+C C$

IGFBP3 polymorphism accounted for $10 \%$ of growth velocity variation $(P=0.004)$ and together with height SDS $(P<0.001)$ and age at the start of rhGH therapy $(P=0.001)$, explained $29 \%$ of observed variation.

\section{Final height SDS}

Clinical and laboratory characteristics, as well as genotype distribution, of the 36 patients who reached adult height were indistinguishable from the 35 patients who were still on treatment. Genotypic groups were similar concerning gender distribution, isolated or combined GHD, spontaneous or induced puberty, age at puberty onset, parental height, highest GH peak, chronological age and bone age delay at the start of treatment, basal height SDS, BMI SDS, and mean rhGH doses (Table 2). Despite similar mean rhGH doses and treatment duration, there was a tendency for better final height growth outcomes in patients with the AA -202 IGFBP3 genotype, but this difference was not significant (Table 2 and Fig. 3 ).

\section{Discussion}

Interest in a search for genetic variations that modulate $\mathrm{rhGH}$ sensitivity and help to explain the great variability in clinical outcomes observed in GHD children during rhGH therapy has increased in the last $5 \mathrm{yr}$. Genes involved in GH and IGF-I action are obvious candidates for rhGH pharmacogenetic studies. Considering that IGFBP-3 modulates both endocrine and local actions of IGF-I, and given the established functional importance of $-202 \mathrm{~A} / \mathrm{C}$ IGFBP3 promoter region polymorphism, we evaluated whether this common polymorphism could influence growth responsiveness to rhGH therapy. Since 2001, genotype at this locus has been consistently correlated to circulating levels of IGFBP-3 in healthy adults (16). In the present study, the effects of this polymorphism on IGFBP-3 levels and growth response to rhGH treatment in children with GHD were assessed for the first time.

Regarding IGFBP-3 serum levels, studies in healthy adults demonstrated that individuals with the AA genotype present mean IGFBP-3 levels higher than patients with AC or CC genotypes (16-23). In our cohort of patients with severe GHD, this association became statistically significant only during $\mathrm{rhGH}$ treatment, which suggests that the effect of the $-202 \mathrm{~A} / \mathrm{C}$ IGFBP3 polymorphism on IGFBP-3 levels may be at least in part dependent on GH action. Theoretically, IGFBP-3 serum levels are determined not only by gene transcriptional activity, but also by posttranslational changes and stabilization in ternary complexes. Other possible influential variables such as acid labile subunit and IGF-2 levels were not evaluated in the present study. However, functional studies and the consistency of correlations between -202 A/C IGFBP3 genotype and IGFBP-3 serum levels in several studies (16-23) support a direct relationship between genotype at this locus and peptide levels.

In contrast with the clear influence of the $-202 \mathrm{~A} / \mathrm{C}$ genotype on IGFBP-3 serum levels, there was no correlation between this polymorphism and IGF-I serum levels, which is in accordance with other studies $(20,22)$ and could be explained by additional influential factors on IGF-I levels $(27,28)$.

Moreover, GHD children who harbor the -202 AA IGFBP3 genotype presented better mean growth velocity during the first year of rhGH treatment than patients harboring -202 AC or CC IGFBP3 genotype. The observed influence of genotype on 


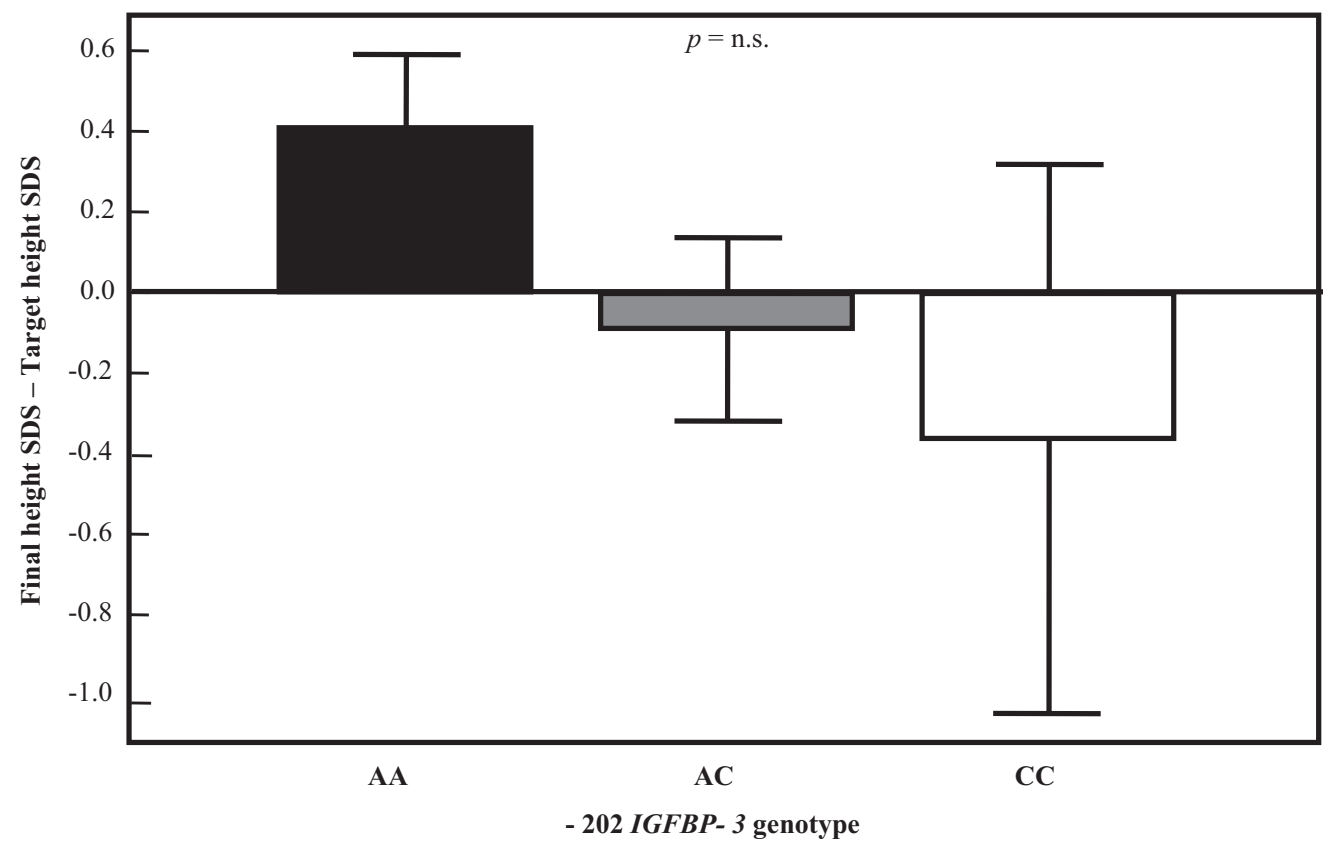

Fig. 3. Mean adult height SDS adjusted for target height SDS in 36 patients with severe GHD after long-term treatment with rhGH, according to -202 A/C IGFBP3 genotype (mean \pm SEM).

growth velocity was independent of other clinical variables, as demonstrated by multiple regression analyses including factors such as gender, target height SDS, age and height SDS at the start of treatment, $\mathrm{GH}$ peak at stimulation tests, and mean rhGH dose during treatment. Pretreatment growth velocity was not available for those analyses due to the severity of short stature in the majority of patients and the prompt GHD diagnosis.

A tendency for better adult height adjusted for target height in patients homozygous for the A allele was also observed, but this difference did not reach statistical significance. One previous study, especially designed to evaluate the association between IGFBP3 polymorphisms and body size, found a weak association between the -202 A IGFBP3 allele and higher adult height in a cohort of Hispanic, but not in non-Hispanic, women (29). A possible explanation for the lack of a clear association between this polymorphism and the height of healthy adults might be the fact that, in individuals with normal GH secretion, slight differences in GH sensitivity could be counterbalanced by a corresponding increase in $\mathrm{GH}$ secretion. Conversely, in patients with severe GHD, who depend on fixed doses of rhGH administered, the adaptive response is impaired, and differences in GH sensitivity will probably be more clearly observed. It is noteworthy that all our patients had severe GHD due to the stringent diagnostic criteria used in our unit. Hence, they comprise a homogenous severe GHD cohort, ideal to evaluate the effect of genetic factors on growth responsiveness to rhGH.

There is much evidence for stimulatory effects of IGFBP-3 on IGF-I action. First, IGFBP-3 prolongs the half-life of IGF-I, thus modulating its endocrine actions $(11,13)$. Moreover, IGFBP-3 can potentiate IGF-I autocrine and paracrine actions, as demonstrated by many in vitro $(30-37)$ and in vivo studies $(38,39)$. Indeed, IGF-I complexed to IGFBP-3 appears to be more potent than free IGF-I under many conditions $(36,38-40)$. Some of the proposed mechanisms for stimulatory effects of IGFBP-3 on IGF-I actions are: 1) IGFBP interaction with cell or matrix components, which may concentrate IGFs near their receptor, enhancing IGF activity and facilitating the storage of IGFs in extracellular matrices for future action $(11,14) ; 2$ ) accumulation of cell-bound forms of IGFBP-3 with lowered affinity for IGF, which may enhance the presentation of IGF to Type 1 IGF-receptor and facilitate a slow exchange of IGF-I between the receptor and IGFBP-3 $(35,41)$; 3) cell protection from IGF-I-mediated downregulation of IGF-I receptor $(33,42)$; 4) potentiation of IGF action mediated through the phosphatidylinositol 3-kinase pathway (32).

In summary, we suggest that the higher levels of IGFBP-3, related to the presence of the -202 AA IGFBP3 genotype, may result in prolonged half-life of the IGF-I/IGFBP-3 complex and/or amplification of IGF-I local effects, thus enhancing rhGH actions. For the first time, a direct relation between the $-202 \mathrm{~A} / \mathrm{C}$ $I G F B P 3$ promoter region polymorphism and responsiveness to rhGH treatment in GHD children was demonstrated. Patients homozygous for the A allele presented better growth velocities and higher IGFBP-3 levels in the first year of rhGH treatment than patients who harbor one or two copies of the $\mathrm{C}$ allele. These results substantiate the importance of pharmacogenetic studies on rhGH treatment and suggest that future studies adjusting rhGH treatment to genotype may provide additional tools to individualization of rhGH therapy and improved growth outcomes.

\section{Acknowledgments}

Address all correspondence and requests for reprints to: Alexander A. L. Jorge, Unidade de Endocrinologia do Desenvolvimento, Laboratorio de Hormonios e Genetica Molecular LIM/42, Faculdade de 
Medicina da Universidade de Sao Paulo, Av. Dr. Enéas de Carvalho Aguiar, no. 155, PAMB, 2 degree andar, bloco 6, São Paulo, Brazil. E-mail: alexj@usp.br.

This work was supported by grants from Fundacao de Amparo a Pesquisa do Estado de Sao Paulo (05/04726-0 and 06/55763-5, to E.F.C.) and from Conselho Nacional de Desenvolvimento Cientifico e Tecnologico-CNPq (307951/06-5 to A.A.L.J., 301246/95-5 to B.B.M., and 300938/06-3 to I.J.P.A.).

Disclosure Statement: The authors declare that they have no competing financial interests.

\section{References}

1. GH Research Society 2000 Consensus guidelines for the diagnosis and treatment of growth hormone (GH) deficiency in childhood and adolescence: summary statement of the GH Research Society. J Clin Endocrinol Metab 85: 3990-3993

2. Ranke MB, Lindberg A, Chatelain P, Wilton P, Cutfield W, Albertsson-Wikland K, Price DA 1999 Derivation and validation of a mathematical model for predicting the response to exogenous recombinant human growth hormone $(\mathrm{GH})$ in prepubertal children with idiopathic GH deficiency. KIGS International Board. Kabi Pharmacia International Growth Study. J Clin Endocrinol Metab 84:1174-1183

3. Carel JC, Ecosse E, Nicolino M, Tauber M, Leger J, Cabrol S, Bastie-Sigeac I, Chaussain JL, Coste J 2002 Adult height after long term treatment with recombinant growth hormone for idiopathic isolated growth hormone deficiency: observational follow up study of the French population based registry. BMJ 325:70

4. de Ridder MA, Stijnen T, Hokken-Koelega AC 2007 Prediction of adult height in growth-hormone-treated children with growth hormone deficiency. J Clin Endocrinol Metab 92:925-931

5. Reiter EO, Price DA, Wilton P, Albertsson-Wikland K, Ranke MB 2006 Effect of growth hormone $(\mathrm{GH})$ treatment on the near-final height of 1258 patients with idiopathic GH deficiency: analysis of a large international database. J Clin Endocrinol Metab 91:2047-2054

6. Blethen SL, Baptista J, Kuntze J, Foley T, LaFranchi S, Johanson A 1997 Adult height in growth hormone (GH)-deficient children treated with biosynthetic GH. The Genentech Growth Study Group. J Clin Endocrinol Metab 82:418-420

7. Dos Santos C, Essioux L, Teinturier C, Tauber M, Goffin V, Bougneres P 2004 A common polymorphism of the growth hormone receptor is associated with increased responsiveness to growth hormone. Nat Genet 36:720-724

8. Jorge AA, Marchisotti FG, Montenegro LR, Carvalho LR, Mendonca BB, Arnhold IJ 2006 Growth hormone (GH) pharmacogenetics: influence of GH receptor exon 3 retention or deletion on first-year growth response and final height in patients with severe GH deficiency. J Clin Endocrinol Metab 91: 1076-1080

9. Blum WF, Machinis K, Shavrikova EP, Keller A, Stobbe H, Pfaeffle RW, Amselem S 2006 The growth response to growth hormone (GH) treatment in children with isolated GH deficiency is independent of the presence of the exon 3-minus isoform of the GH receptor. J Clin Endocrinol Metab 91: 4171-4174

10. Baxter RC 2000 Insulin-like growth factor (IGF)-binding proteins: interactions with IGFs and intrinsic bioactivities. Am J Physiol Endocrinol Metab 278:E967-E976

11. Mohan S, Baylink DJ 2002 IGF-binding proteins are multifunctional and act via IGF-dependent and -independent mechanisms. J Endocrinol 175:19-31

12. Rosenzweig SA 2004 What's new in the IGF-binding proteins? Growth Horm IGF Res 14:329-336

13. Zapf J 1995 Physiological role of the insulin-like growth factor binding proteins. Eur J Endocrinol 132:645-654

14. Firth SM, Baxter RC 2002 Cellular actions of the insulin-like growth factor binding proteins. Endocr Rev 23:824-854

15. Harrela M, Koistinen H, Kaprio J, Lehtovirta M, Tuomilehto J, Eriksson J, Toivanen L, Koskenvuo M, Leinonen P, Koistinen R, Seppala M 1996 Genetic and environmental components of interindividual variation in circulating levels of IGF-I, IGF-II, IGFBP-1, and IGFBP-3. J Clin Invest 98 2612-2615

16. Deal C, Ma J, Wilkin F, Paquette J, Rozen F, Ge B, Hudson T, Stampfer M, Pollak M 2001 Novel promoter polymorphism in insulin-like growth factorbinding protein-3: correlation with serum levels and interaction with known regulators. J Clin Endocrinol Metab 86:1274-1280
17. Al-Zahrani A, Sandhu MS, Luben RN, Thompson D, Baynes C, Pooley KA, Luccarini C, Munday H, Perkins B, Smith P, Pharoah PD, Wareham NJ, Easton DF, Ponder BA, Dunning AM 2006 IGF1 and IGFBP3 tagging polymorphisms are associated with circulating levels of IGF1, IGFBP3 and risk of breast cancer. Hum Mol Genet 15:1-10

18. Cheng I, DeLellis Henderson K, Haiman CA, Kolonel LN, Henderson BE, Freedman ML, Le Marchand L 2007 Genetic determinants of circulating insulin-like growth factor (IGF)-I, IGF binding protein (BP)-1, and IGFBP-3 levels in a multiethnic population. J Clin Endocrinol Metab 92:3660-3666

19. Jernstrom H, Deal C, Wilkin F, Chu W, Tao Y, Majeed N, Hudson T, Narod SA, Pollak M 2001 Genetic and nongenetic factors associated with variation of plasma levels of insulin-like growth factor-I and insulin-like growth factorbinding protein-3 in healthy premenopausal women. Cancer Epidemiol Biomarkers Prev 10:377-384

20. Morimoto LM, Newcomb PA, White E, Bigler J, Potter JD 2005 Variation in plasma insulin-like growth factor-1 and insulin-like growth factor binding protein-3: genetic factors. Cancer Epidemiol Biomarkers Prev 14:13941401

21. Ren Z, Cai Q, Shu XO, Cai H, Li C, Yu H, Gao YT, Zheng W 2004 Genetic polymorphisms in the IGFBP3 gene: association with breast cancer risk and blood IGFBP-3 protein levels among Chinese women. Cancer Epidemiol Biomarkers Prev 13:1290-1295

22. Schernhammer ES, Hankinson SE, Hunter DJ, Blouin MJ, Pollak MN 2003 Polymorphic variation at the -202 locus in IGFBP3: influence on serum levels of insulin-like growth factors, interaction with plasma retinol and vitamin D and breast cancer risk. Int J Cancer 107:60-64

23. Slattery ML, Baumgartner KB, Byers T, Guiliano A, Sweeney C, Herrick J, Curtin K, Murtaugh M, Wolff R 2005 Genetic, anthropometric, and lifestyle factors associated with IGF-1 and IGFBP-3 levels in Hispanic and non-Hispanic white women. Cancer Causes Control 16:1147-1157

24. Tanner JM, Whitehouse RH, Takaishi M 1966 Standards from birth to maturity for height, weight, height velocity, and weight velocity: British children, 1965. I. Arch Dis Child 41:454-471

25. Tanner JM, Whitehouse RH, Takaishi M 1966 Standards from birth to maturity for height, weight, height velocity, and weight velocity: British children, 1965. II. Arch Dis Child 41:613-635

26. Greulich WW, Pyle SI 1959 Radiographic atlas of skeletal development of the hand and wrist. Palo Alto, CA: Stanford University Press

27. Milani D, Carmichael JD, Welkowitz J, Ferris S, Reitz RE, Danoff A, Kleinberg DL 2004 Variability and reliability of single serum IGF-I measurements: impact on determining predictability of risk ratios in disease development. J Clin Endocrinol Metab 89:2271-2274

28. Clemmons DR 2001 Commercial assays available for insulin-like growth factor I and their use in diagnosing growth hormone deficiency. Horm Res 55(Suppl 2):73-79

29. Sweeney C, Murtaugh MA, Baumgartner KB, Byers T, Giuliano AR, Herrick JS, Wolff R, Caan BJ, Slattery ML 2005 Insulin-like growth factor pathway polymorphisms associated with body size in Hispanic and non-Hispanic white women. Cancer Epidemiol Biomarkers Prev 14:1802-1809

30. Ernst M, Rodan GA 1990 Increased activity of insulin-like growth factor (IGF) in osteoblastic cells in the presence of growth hormone $(\mathrm{GH})$ : positive correlation with the presence of the GH-induced IGF-binding protein BP-3. Endocrinology 127:807-814

31. Conover CA, Clarkson JT, Bale LK 1996 Factors regulating insulin-like growth factor-binding protein-3 binding, processing, and potentiation of insulin-like growth factor action. Endocrinology 137:2286-2292

32. Conover CA, Bale LK, Durham SK, Powell DR 2000 Insulin-like growth factor (IGF) binding protein-3 potentiation of IGF action is mediated through the phosphatidylinositol-3-kinase pathway and is associated with alteration in protein kinase B/AKT sensitivity. Endocrinology 141:3098-3103

33. Chen JC, Shao ZM, Sheikh MS, Hussain A, LeRoith D, Roberts Jr CT, Fontana JA 1994 Insulin-like growth factor-binding protein enhancement of insulinlike growth factor-I (IGF-I)-mediated DNA synthesis and IGF-I binding in a human breast carcinoma cell line. J Cell Physiol 158:69-78

34. Butt AJ, Martin JL, Dickson KA, McDougall F, Firth SM, Baxter RC 2004 Insulin-like growth factor binding protein-3 expression is associated with growth stimulation of T47D human breast cancer cells: the role of altered epidermal growth factor signaling. J Clin Endocrinol Metab 89:1950-1956

35. De Mellow JS, Baxter RC 1988 Growth hormone-dependent insulin-like growth factor (IGF) binding protein both inhibits and potentiates IGF-I-stimulated DNA synthesis in human skin fibroblasts. Biochem Biophys Res Commun 156:199-204

36. Blum WF, Jenne EW, Reppin F, Kietzmann K, Ranke MB, Bierich JR 1989 Insulin-like growth factor I(IGF-I)-binding protein complex is a better mitogen than free IGF-I. Endocrinology 125:766-772 
37. Ramagnolo D, Akers RM, Byatt JC, Wong EA, Turner JD 1994 IGF-I-induced IGFBP-3 potentiates the mitogenic actions of IGF-I in mammary epithelia MD-IGF-I cells. Mol Cell Endocrinol 102:131-139

38. Bagi CM, DeLeon E, Brommage R, Rosen D, Sommer A 1995 Treatment of ovariectomized rats with the complex of rhIGF-I/IGFBP-3 increases cortical and cancellous bone mass and improves structure in the femoral neck. Calcif Tissue Int 57:40-46

39. Narusawa K, Nakamura T, Suzuki K, Matsuoka Y, Lee LJ, Tanaka H, Seino Y 1995 The effects of recombinant human insulin-like growth factor (rhIGF)- 1 and rhIGF1/IGF binding protein-3 administration on rat osteopenia induced by ovariectomy with concomitant bilateral sciatic neurectomy. J Bone Miner Res 10:1853-1864
40. Kupfer SR, Underwood LE, Baxter RC, Clemmons DR 1993 Enhancement of the anabolic effects of growth hormone and insulin-like growth factor I by use of both agents simultaneously. J Clin Invest 91:391-396

41. Conover CA 1991 Glycosylation of insulin-like growth factor binding protein-3 (IGFBP-3) is not required for potentiation of IGF-I action: evidence for processing of cell-bound IGFBP-3. Endocrinology 129:32593268

42. Conover CA, Powell DR 1991 Insulin-like growth factor (IGF)binding protein-3 blocks IGF-I-induced receptor down-regulation and cell desensitization in cultured bovine fibroblasts. Endocrinology 129 : $710-716$ 